San Jose State University

SJSU ScholarWorks

Master's Theses

Master's Theses and Graduate Research

Spring 2020

\title{
Lithology, Structure, Geochronology, and Tectonic Implications of the Spider Glacier Unit and Holden Assemblage, North Cascades, Washington
}

Colin Phillips

San Jose State University

Follow this and additional works at: https://scholarworks.sjsu.edu/etd_theses

\section{Recommended Citation}

Phillips, Colin, "Lithology, Structure, Geochronology, and Tectonic Implications of the Spider Glacier Unit and Holden Assemblage, North Cascades, Washington" (2020). Master's Theses. 5108.

DOI: https://doi.org/10.31979/etd.wcje-w4t5

https://scholarworks.sjsu.edu/etd_theses/5108

This Thesis is brought to you for free and open access by the Master's Theses and Graduate Research at SJSU ScholarWorks. It has been accepted for inclusion in Master's Theses by an authorized administrator of SJSU ScholarWorks. For more information, please contact scholarworks@sjsu.edu. 
LITHOLOGY, STRUCTURE, GEOCHRONOLOGY AND TECTONIC IMPLICATIONS OF THE SPIDER GLACIER UNIT AND HOLDEN ASSEMBLAGE, NORTH CASCADES, WASHINGTON

\author{
A Thesis \\ Presented to \\ The Faculty of the Department of Geology \\ San José State University \\ In Partial Fulfillment \\ of the Requirements for the Degree \\ Master of Science
}

by

Colin Phillips

May 2020 
(C) 2020

Colin Phillips

ALL RIGHTS RESERVED 
The Designated Thesis Committee Approves the Thesis Titled

\section{LITHOLOGY, STRUCTURE, GEOCHRONOLOGY AND TECTONIC IMPLICATIONS OF THE SPIDER GLACIER UNIT AND HOLDEN ASSEMBLAGE, NORTH CASCADES, WASHINGTON}

by

Colin Phillips

APPROVED FOR THE DEPARTMENT OF GEOLOGY

SAN JOSÉ STATE UNIVERSITY

May 2020
Dr. Robert Miller
Department of Geology
Dr. Ellen Metzger
Department of Geology
Dr. Jonathan Miller
Department of Geology 


\section{ABSTRACT \\ LITHOLOGY, STRUCTURE, GEOCHRONOLOGY AND TECTONIC IMPLICATIONS OF THE SPIDER GLACIER UNIT AND HOLDEN ASSEMBLAGE, NORTH CASCADES, WASHINGTON \\ by Colin Phillips}

To understand the effects of deeply emplaced sediments on continental magmatic arcs, researchers study crustal cross sections where meta-sediments are exposed at the surface, such as in the North Cascades of Washington. The 8-12 kbar Swakane Biotite Gneiss has been considered the deepest meta-sedimentary unit in the section, but my mapping shows that the adjacent Spider Glacier unit is structurally lower. The Spider Glacier unit consists of biotite and hornblende gneisses, quartzites and rare metaperidotites, all deformed by highly variably oriented folds with a mean moderate west plunge. My $\mathrm{U}-\mathrm{Pb}$ dating of detrital zircon indicates that the maximum depositional age (MDA) of the Spider Glacier unit is $\sim 118-110 \mathrm{Ma}$, which is older than the 93-81 Ma MDA of the Swakane Gneiss. The only rare folding in the Gneiss implies that a tectonic contact separates it from the Spider Glacier unit. Based on rock types and detrital zircon age patterns, the Spider Glacier unit was likely deposited outboard of the Cordilleran arc at $110 \mathrm{Ma}$ or later, incorporated into the arc and folded and metamorphosed between 110-74 Ma, and imbricated with the Swakane Gneiss between 74-65 Ma. The age data indicate the Spider Glacier unit is a Cretaceous component of the Cascade River-Holden assemblage. U-Pb ages of zircons in the Holden Village area support recent work suggesting that the assemblage includes Late Permian intrusive rocks. The Late Permian rocks are likely separated from the Cretaceous rocks by an unrecognized boundary. 


\section{ACKNOWLEDGMENT}

The timely completion of this work would not have been possible without generous support from the following individuals: Bob Miller, whose technical writing skills are unmatched, for guidance, life lessons, and for showing me how to craft "classic" scientific literature, though I do not claim to having crafted any; Stacia Gordon, University of Nevada, Reno (UNR), for the use of her lab and for not telling my advisor that I broke a $\$ 550$ beaker and burned my eyes with an ultraviolet (UV) lamp; Kirsten Sauer and Joel DesOrmeau, UNR, for providing their time during the zircon imaging process; Chris Russo, Oregon State University (OSU), for providing a flexible schedule in operating the LA-ICP-MS. Adam Kent, OSU, and Nansen H. Olson (Ph.D Candidate) for processing our zircon data and extinguishing the lab fire that absconded it for three months; Jonathan Miller and Ellen Metzger, for providing insightful feedback during the writing process; Nataša Budimirović, for practicing tolerance for two field seasons, sharing homelessness, and performing feats of mountaineering that were likely certainly beyond her level of comfort; Leslie Blum, for ensuring I did not misplace the papers necessary for my continued enrollment graduation; Ginny Smith, for keeping the computers, and thus my thesis, up and running; Alphonse Odisho, for tackling tasks relating to vital equipment with timely scrupulous care, and for putting my rock samples to bed; John Lee and Jesse Waco, for comic relief; The National Science Foundation for paying for campgrounds and consumables (EAR1419810); Above all, I would like to thank my parents - without whom I would not be a person, let alone the one that I was yesterday_-for supporting me during this tumultuous epoch of my life. 


\section{TABLE OF CONTENTS}

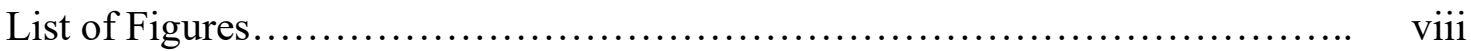

List of Tables.....................................................................

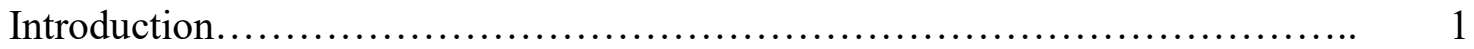

Purpose of Study ....................................................... 2

Background......................................................... 3

Methods....................................................................... 12

Lithologies.............................................................. 13

Holden Assemblage ............................................... 13

Amphibolite................................................... 17

Biotite Gneiss.................................................... 17

Hornblende Gneiss.............................................. 18

Calc-silicate Gneiss.............................................. 18

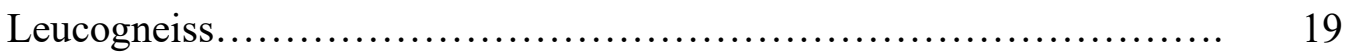

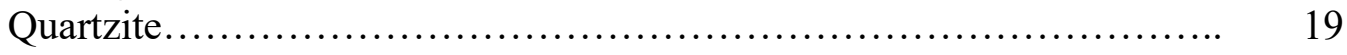

Marble .......................................................... 20

Spider Glacier Unit................................................ 20

Hornblende-biotite Gneiss...................................... 24

Hornblende Gneiss................................................. 26

Micaceous Quartzite............................................. 27

Biotite Gneiss................................................... 29

Meta-peridotite..................................................... 31

Igneous Intrusive Rocks........................................ 31

Swakane Gneiss.................................................. 33

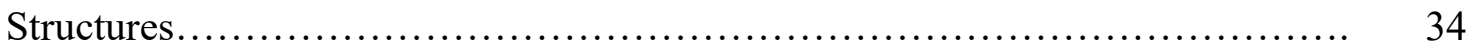

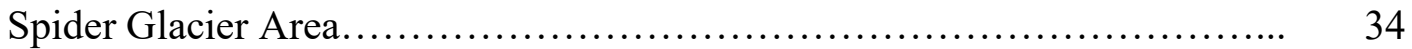

Holden Village Area................................................ 51

Carne Mountain Area................................................ 53

Rock Creek Area................................................. 55

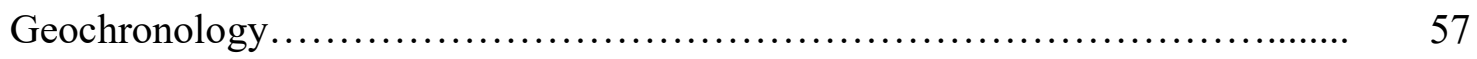

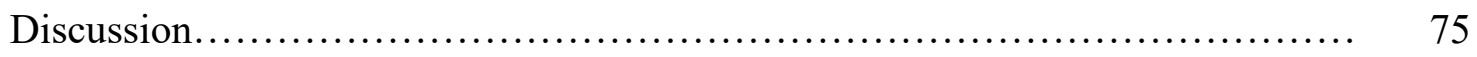

Origin of the Spider Glacier Unit..................................... 75

Burial Mechanism................................................ 80

Anomalous Folds ................................................. 81

Chiwawa Discontinuity ............................................ 81

Original Position of the Spider Glacier Unit.............................. 83 
Spider Glacier unit: Part of the Holden Assemblage?................................ $\quad 84$

Cascade River-Holden Arc............................................. 85

Conclusions............................................................ 86

References........................................................... 88

Appendix A: EBSD Post-Processing Procedure............................... 97

Appendix B: Zircon Separation Procedure (SJSU)........................... 98

Appendix C: Zircon Separation Procedure (UNR) ........................... 99

Appendix D: Preparation of FESEM Mount............................... 100 


\section{LIST OF FIGURES}

Figure 1. Generalized geologic map of western North America............. 4

Figure 2. Simplified map with parts of Washington and British Columbia.. 6

Figure 3. Map showing locations of field areas........................ 10

Figure 4. Geologic map of the Holden Village area...................... 15

Figure 5. Geologic map of the Rock Creek area....................... 16

Figure 6. Geologic map of the Spider Glacier area........................ 22

Figure 7A. Detailed geologic map of the Spider Glacier area................ 23

Figure 7B. Cross sections through the area shown on Figure 7A............ 24

Figure 8. Photograph of hornblende-biotite gneiss of the Spider Glacier unit. 25

Figure 9. Photograph of micaceous quartzite of the Spider Glacier unit..... 28

Figure 10. Photomicrograph of micaceous quartzite..................... 29

Figure 11. Photograph of biotite gneiss of the Spider Glacier unit .......... 30

Figure 12. Photograph of meta-peridotite of the Spider Glacier unit............ 32

Figure 13. Foliations and mineral lineations in the Swakane Gneiss........ 35

Figure 14. Poles to foliation and fold axes in the Spider Glacier unit.......... 36

Figure 15. Foliations and mineral lineations in the Spider Glacier unit........ 37

Figure 16. Structural map of the Spider Glacier area.................... 38

Figure 17. $\quad F_{2}$ kink fold in hornblende-biotite gneiss...................... 41

Figure 18. Type-III fold interference pattern in hornblende-biotite gneiss.... 41

Figure 19. Outcrop-scale fold in the Spider Glacier area.................... 42

Figure 20. Zone of top-to-the-south, sinistral-normal shear................ 43 
Figure 21. Photograph of the Chiwawa discontinuity..................... 44

Figure 22. Schematic of expected c-axis orientations for quartz slip systems 46

Figure 23. Plots of quartz c-axis orientations from three samples............ 48

Figure 24. Photomicrograph of SG17-114............................ 50

Figure $25 \quad$ Poles to foliation and lineations in the Holden Village area....... 52

Figure 26. Poles to foliation and fold axes in the Carne Mountain area....... 55

Figure 27. Poles to foliation and lineations in the Rock Creek area............ 57

Figure 28. Cathodoluminescence (CL) imagery of zircons from SG17-068.2 59

Figure 29. Scatter plot showing Th/U by age for zircons in SG17-068.2...... 61

Figure 30. Age distribution of SG17-068.2 zircons with $\mathrm{Th} / \mathrm{U}>0.9 \ldots \ldots \ldots \ldots$

Figure 31. Concordia plot for zircons from SG17-068.2.................. 63

Figure 32. Probability density plots (PDPs) for SG17-068.2 and SK18-05..... 64

Figure 33. CL imagery of zircons from the Holden assemblage (SK18-05)... 66

Figure 34. Concordia plot for zircons from SK18-05..................... 67

Figure 35. Scatter plot of $\mathrm{Th} / \mathrm{U}$ by age for all zircon grains for SK18-05..... 68

Figure 36. Weighted mean age distribution for zircons from SK18-05....... 69

Figure 37. Probability density plots (PDP) for zircons from SG18-025....... 71

Figure 38. Scatter plot of Th/U for zircon grains, cores and rims in SG18-025 72

Figure 39. Concordia plot for zircons from SG18-025.................. 73

Figure 40. Concordia plot for $<350 \mathrm{Ma}$ zircons from SG18-025............. 74 


\section{LIST OF TABLES}

Table 1. Zircon age ranges for Mesozoic source rocks within the Cordillera.... 77

Table 2. Zircon ages for back-arc, fore-arc and accretionary wedge units...... 79 


\section{INTRODUCTION}

Numerous studies have found that metasedimentary rocks are emplaced deeply in the crust of continental magmatic arcs during arc shortening (e.g., Haxel et al., 1978; Grove et al., 2003; Chapman, 2016). The presence of supracrustal material at middle- to lowercrustal levels in arcs is proposed to have broad effects, from fueling periods of voluminous arc magmatism (e.g., Ducea and Barton, 2007; DeCelles et al., 2009), to creating strength contrasts where strain may be localized (e.g., Miller and Paterson, 2001), and even making the crust more felsic over time (e.g., Ducea and Barton, 2007; Otamendi et al., 2008; Behn et al., 2011).

To investigate these effects, studies use exhumed crustal sections of continental magmatic arcs where deeply ( $\geq 25 \mathrm{~km}$ ) buried metasedimentary rocks are exposed (e.g., Haxel et al., 1978; Matzel et al., 2004; Chapman, 2016). One such crustal section is the crystalline core of the North Cascades of Washington (Cascades core) and southern British Columbia, which exposes $0-40 \mathrm{~km}$ of paleodepth through a Cretaceous-Eocene continental magmatic arc (Miller and Paterson, 2001). Within the Cascades core, two of the most deeply exhumed metasedimentary rock units are the Skagit Gneiss Complex and the Swakane Biotite Gneiss (Tabor et al., 1989; Haugerud et al., 1991; Miller and Paterson, 2001).

The most deeply exhumed of the two, the Swakane Biotite Gneiss (hereafter referred to as the Swakane Gneiss) is the base of the Cascades core crustal section (Miller and Paterson, 2001), and represents fore-arc sediments deposited between 93-81 Ma (Sauer et al., 2017a; 2019). Studies of the Swakane Gneiss support arguments that sediments are 
emplaced into arcs rapidly by underthrusting (Matzel, 2004; Sauer et al., 2017a; 2019). However, other workers have promulgated that sediments are either underplated during subduction (e.g. Chapman, 2016), or partially melted during subduction to form buoyant material which laminates to the base of the arc crust (e.g. Hacker et al., 2011). Studies of the Swakane Gneiss have failed to support the later arguments. However, according to estimates of mid-Cretaceous crustal thickness $(\geq 60 \mathrm{~km})$ in the Cascades core, at least 15 km of crust lay beneath the Swakane Gneiss (Miller and Paterson, 2001. Furthermore, mapping by early workers in the North Cascades (Cater and Crowder, 1967) shows that a $<1 \mathrm{~km}$ wide, $\geq 10$-km-long body of rocks (referred to herein as the Spider Glacier unit) may structurally underlie the Swakane Gneiss. If so, the Spider Glacier unit potentially preserves a record of the processes occurring beneath the Swakane Gneiss, and may further elucidate the mechanisms which led to the unit's deep emplacement within the crust.

\section{Purpose of Study}

The purposes of this study are to: 1) characterize the lithology and structure of the Spider Glacier unit; 2) use U-Pb dating of detrital zircon to surmise the age and origin of the Spider Glacier unit protolith; 3) compare the Spider Glacier unit lithologies, structures, and U-Pb zircon ages with those of the Holden assemblage; 4) determine if the contact between the Spider Glacier unit and Swakane Gneiss is a tectonic or nontectonic contact; and ultimately, 5) determine if the Spider Glacier unit represents deeper levels than the Swakane Gneiss. These research goals are addressed with field mapping, thin section petrography, and $\mathrm{U}-\mathrm{Pb}$ dating of zircon. 


\section{Background}

The North Cascades core is located at the southern termination of the Coast Plutonic Complex, a belt of plutonic and metamorphic rocks extending from Washington to Alaska that represents an exhumed Cretaceous to Eocene continental arc (Figure 1) (e.g., Misch, 1966; Tabor et al., 1989; Gehrels et al., 2009). The Cascades core and southern Coast Mountains record mid-Cretaceous ( 115-80 Ma) crustal shortening, metamorphism, and magmatism, Late Cretaceous transpression, and Eocene magmatism and transtension (e.g., Tabor et al., 1989; Rubin et al., 1990; McGroder, 1991; Journeay and Friedman, 1993; Umhoefer and Miller, 1996). Mid-Cretaceous shortening was linked to either an increase in plate coupling or the suturing of the outboard Insular superterrane to the continental margin (e.g., Rubin et al., 1990; McGroder, 1991). In the Cascades core, shortening was coeval with middle- to upper-amphibolite-facies metamorphism, and was accommodated by folding into generally north-south to northwest-southeasttrending open folds, fold-associated cleavage development, shearing along top-to-thesouthwest ductile shear zones, and development of a shallow orogen-parallel stretching lineation (Miller and Paterson, 2001; Miller et al., 2006).

Shortening, crustal thickening and metamorphism overlapped with the largest pulse of magmatism in the Cascades core at ca. 96-88 Ma (Miller et al., 2009). Plutonism resurged between 78-71 Ma, with smaller bodies intruded as late as $60 \mathrm{Ma}$, followed by a magmatic lull (Miller et al., 2009). Magmatism resumed between 50-45 Ma (Haugerud et al., 1991; Miller et al., 2016). In the southwestern Cascades core, exhumation shortly followed crustal thickening and pluton emplacement (e.g., Tabor et al., 1989), but the 


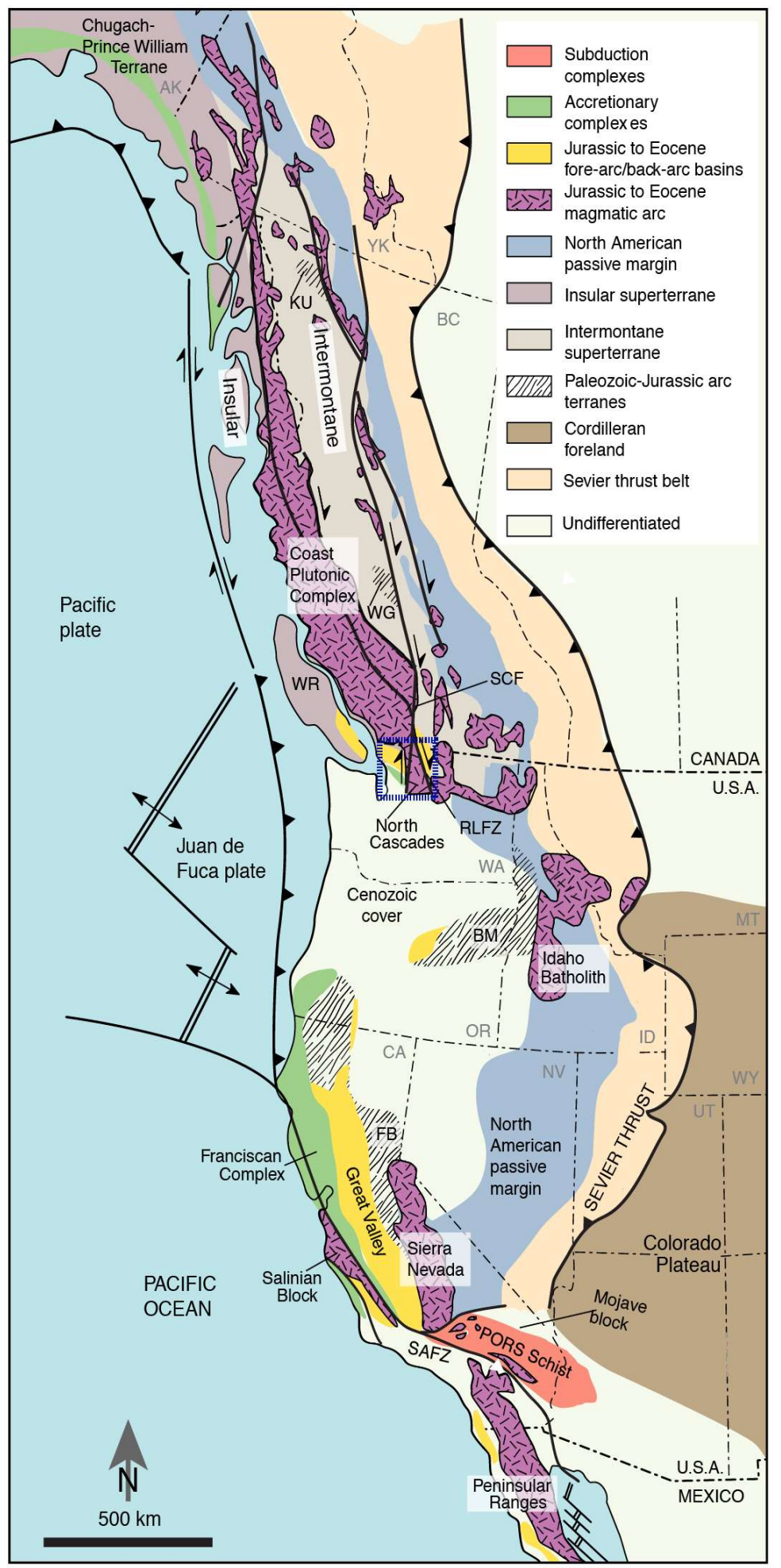

Figure 1. Generalized geologic map of western North America. Major tectonic elements, sedimentary basins and terranes are emphasized. Modified from Sauer et al. (2017a). BM-Blue Mountains; FB-Foothills Belt; KU-Kutcho assemblage; RLFZ-Ross Lake fault zone; SAFZSan Andreas fault zone; SCF-Straight CreekFraser fault; WGWineglass assemblage. 
northern part of the core remained at depth until ca. $45 \mathrm{Ma}$ and records later plutonism and transtension (Haugerud et al., 1991; Miller et al., 2016).

Between 90 and $55 \mathrm{Ma}$, during dominantly dextral transpression, several large terranes, including the Insular and Intermontane superterranes, were translated northward along the arc by strike-slip faulting (e.g., Beck et al., 1981; Umhoefer, 1987). The exact faults responsible are not known, and the magnitude of terrane displacement is controversial. Paleomagnetic data from sedimentary, volcanic and plutonic rocks in Washington and British Columbia suggest the Cascades core was translated northward from the latitude of modern-day Baja California ("Baja-BC hypothesis") (e.g., Umhoefer, 1987), but geologic data support more moderate displacements (Wyld et al., 2006). By restoring estimated offset of known strike-slip faults in Washington, British Columbia and Yukon territory, Wyld et al. (2006) restored the ca. 100 Ma location of the Cascades core to roughly the latitude of central Oregon. In sum, the exact magnitude of displacement for these large terranes remains a subject of debate.

In the Eocene, changes in plate motions caused a shift from dominantly dextral transpression, to transtension (e.g., Miller and Bowring, 1990; Haugerud et al., 1991). By $45 \mathrm{Ma}$, exhumation exposed $\sim 40 \mathrm{~km}$ of paleodepths within the Cascades core (Miller and Paterson, 2001; Paterson et al., 2004). The presently exposed Cascades core is separated from lower-grade rocks to the west and east, and internally divided into two blocks, by high-angle dextral strike-slip faults (Figure 2). The Straight Creek-Fraser fault separates the core from the northwest Cascades system to the west (Misch, 1966), and between 


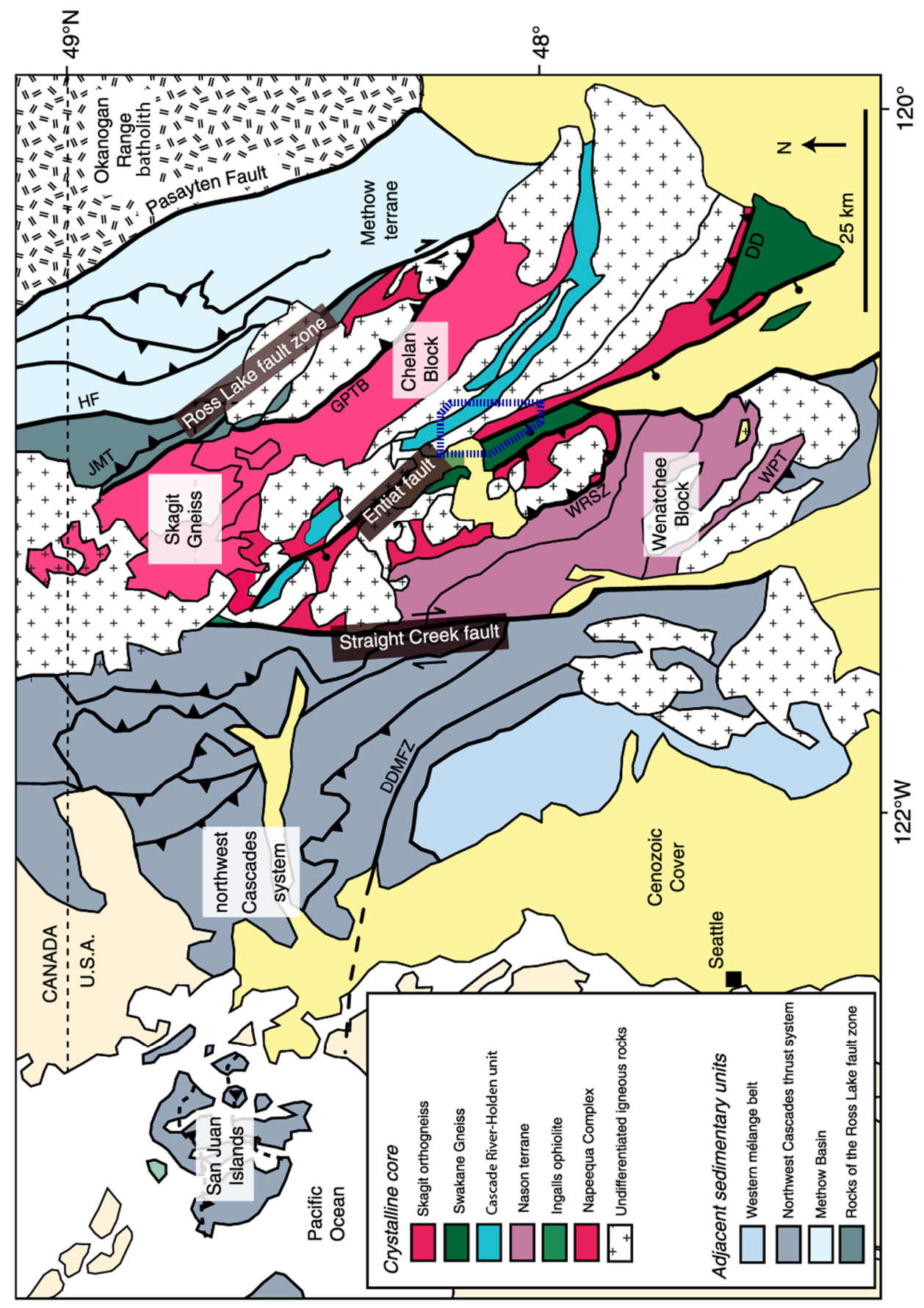

Figure 2. Simplified map with parts of Washington and British Columbia. Strike-slip faults separate the North Cascades crystalline core from lower-grade rocks to the west and east. A dashed blue box denotes the boundaries of Figure 3. Modified from Gordon et al. (2017). DDMFZ-Darrington-Devils Mountain fault zone; DD-Dinkelman décollement; GPT-Gabriel Peak tectonic belt; HF-Hozameen fault; JMT-Jack Mountain thrust; WRSZ-White River shear zone; WPT-Windy Pass thrust. 
$48 \mathrm{Ma}$ and $34 \mathrm{Ma}$, translated the Cascades core 110-170 km southward from equivalent rocks in British Columbia (e.g. Umhoefer and Miller, 1996; Monger and Brown, 2016). The Entiat fault divides the core into the Wenatchee and Chelan blocks and is attributed to have 30-40 km of Eocene dextral separation and an unknown amount of normal slip (Figure 2) (Tabor et al., 1987). The Ross Lake fault zone separates the Chelan block from the Methow basin and eastern Cascades fold belt to the east (Misch, 1966). The Ross Lake fault zone accommodated dextral slip with Paleocene reverse and Eocene normal slip (Miller and Bowring, 1990; Haugerud et al., 1991).

Exhumation was unequally distributed across the Cascades core (e.g., Paterson et al., 2004). In the Wenatchee block, it occurred shortly after crustal thickening and early magmatism (ca. 96-88 Ma). This block has 96 Ma to 84 Ma plutons (e.g. Walker and Brown, 1991), and host rocks with largely Cretaceous K/Ar- and Ar/Ar-biotite cooling ages (Tabor et al., 1989; Haugerud et al., 1991). In contrast, part of the Chelan block remained at depth until ca. $45 \mathrm{Ma}$. The block records magmatism from $96 \mathrm{Ma}$ to $45 \mathrm{Ma}$ (Tabor et al., 1989; Miller et al., 2009) and it was exhumed rapidly between 50-45 Ma (e.g., Wernicke and Getty, 1997; Gordon et al., 2010). Both structural blocks contain dominantly amphibolite-facies host rocks and meta-sedimentary rock units that were exhumed from great depths ( $\geq 40 \mathrm{~km})$ (Figure 2).

The blocks of the Cascades core have further been divided into multiple tectonostratigraphic units. The Napeequa Complex occurs in both the Chelan and Wenatchee blocks, is an oceanic accretionary assemblage (Tabor et al., 1989), and is at least in part Middle Triassic in age (Sauer et al., 2017a). The dominant rock types are 
amphibolite, siliceous schist, and biotite schist, with local calc-silicate rock, marble and meta-peridotite (Cater and Crowder, 1967; Tabor et al., 1989; Brown et al., 1994; Miller et al., 1994). The 9-11 kbar Napeequa Complex (Valley et al., 2003) was thrust above the Swakane Gneiss during Late Cretaceous contraction (Paterson et al., 2004). The thrust was reactivated as a detachment fault (Dinkelman décollement) in the Eocene and records top-to-the-north and -northeast non-coaxial shear related to exhumation of the Swakane Gneiss (Paterson et al., 2004).

The Holden assemblage occurs mostly in the Chelan block as part of a northwesttrending belt. The assemblage extends from the Chelan Migmatite complex in the southeast, to the Straight Creek-Fraser fault in the northwest (Figure 2). In the northwestern part of the Chelan block, the Holden assemblage grades into the Cascade River Schist (Misch, 1966; Brown et al., 1994; Miller et al., 1994); collectively, they constitute the Cascade River-Holden assemblage of Miller et al. (1994). The Holden assemblage is dominated by hornblende-rich schist and gneiss, biotite schist and gneiss, and amphibolite, with lesser calc-silicate gneiss, marble, quartzite and metapelite.

The age of the Cascade River-Holden assemblage is poorly constrained. Early workers considered it cogenetic with the Late Triassic Marblemount-Dumbell plutonic suite (e.g., Tabor et al., 1989; Brown et al., 1994), but further dating has shown that portions of the Cascade River-Holden assemblage were deposited in the Cretaceous (Sauer et al., 2017a), and others were intruded by Late Permian orthogneisses (Mattinson, 1972; Schermer, 2017; this study). Thus, the Cascade River-Holden assemblage clearly includes rocks of different ages and uncertain relations to one another. 
East of the Cascade River-Holden assemblage belt is the Skagit Gneiss Complex (hereafter referred to as the Skagit Gneiss), which forms a northwest-southeast trending belt from the Cascade River-Holden assemblage in the west to the Ross Lake fault zone in the east (Figure 2) (Misch, 1966). The Skagit Gneiss is dominantly orthogneiss, and contains some paragneiss with subordinate amphibolite, calc-silicate rock, quartzite, meta-peridotite and rare metapelite (Misch, 1966; 1968; Haugerud et al., 1991; Tabor and Haugerud, 1999). Metasedimentary rocks in the Skagit Gneiss have maximum deposition ages (MDAs) between $130 \mathrm{Ma}$ and $96 \mathrm{Ma}$ (Sauer et al., 2017b).

The Spider Glacier unit is an informal name for rocks in the northeastern part of the Wenatchee block, near the Entiat fault, which are mapped as Holden assemblage by Cater and Crowder (1967), Napeequa Complex by Haugerud and Tabor (2009), and migmatitic gneiss by Boysun (2004). The Spider Glacier unit contains meta-peridotites, which are uncharacteristic of the Holden assemblage, and a meta-sedimentary sample of the unit yielded a single MDA of 115-110 Ma (K. Sauer, written communication), which is much younger than Napeequa Complex rocks elsewhere.

The Spider Glacier unit is separated from the Swakane Gneiss to the west by a contact mapped as stratigraphic by Cater and Crowder (1967) (Figure 3). Foliation within the Spider Glacier unit and the Swakane Gneiss are subparallel (Cater and Crowder, 1967), suggesting that if the contact is not a fault or overturned, the Spider Glacier unit is deeper, stratigraphically. 


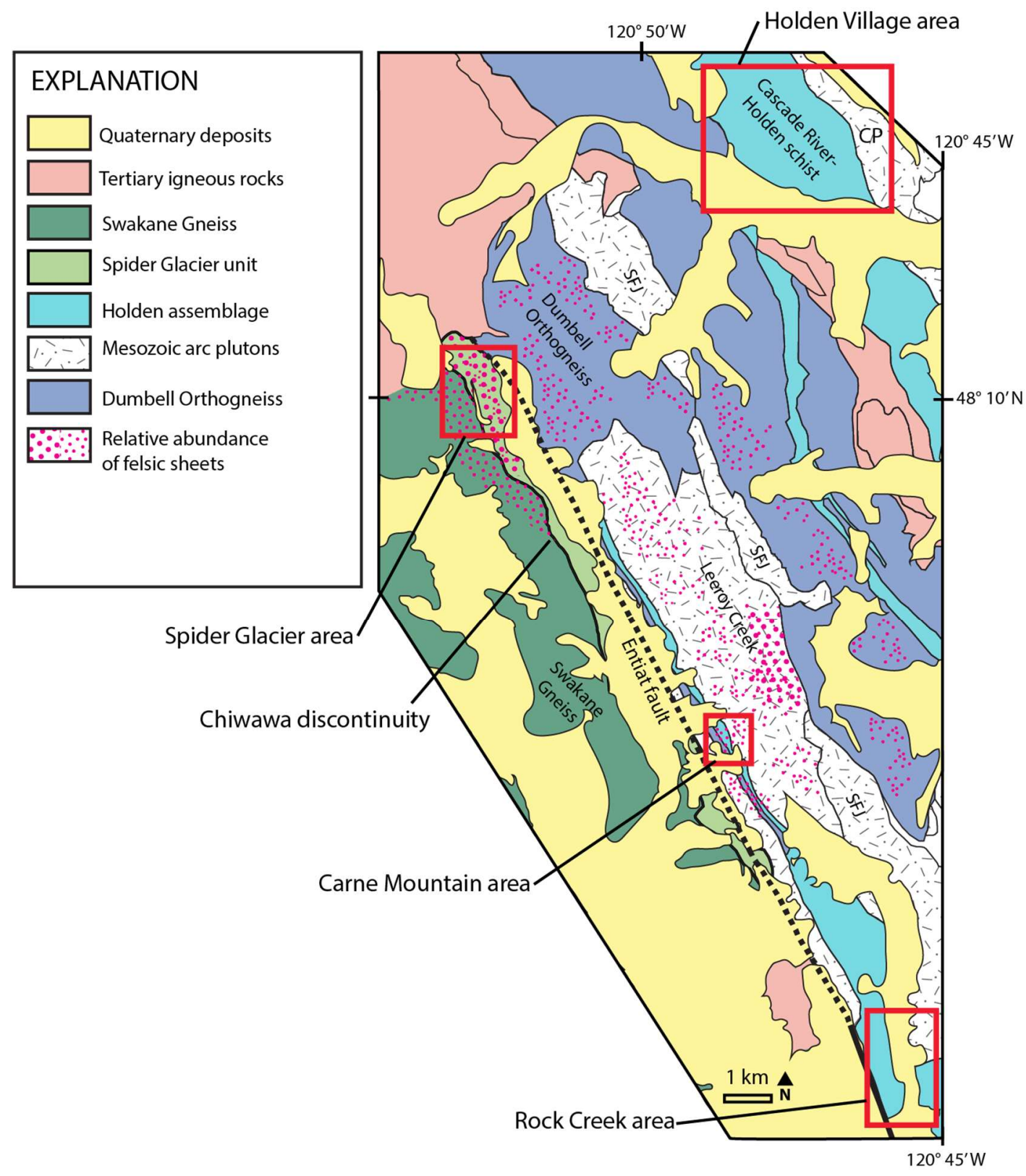

Figure 3. Map showing locations of field areas. Modified from Cater and Crowder (1967) and Cater and Wright (1967). CP-Cardinal Peak; DH-Duncan Hill; SFJ-SevenFingered Jack. 
The Swakane Gneiss occurs in two bodies. In the Chelan block, the Gneiss forms a regional, open, gently plunging antiform in the footwall of a regional detachment, the Dinkelman décollement (Figure 2) (Paterson et al., 2004). In the Wenatchee block, a northwest-trending belt of Swakane Gneiss lies between the Spider Glacier unit on the east, and the Napeequa Complex on the west (Crowder et al., 1966; Cater and Crowder, 1967). The Gneiss and Napeequa Complex are in contact along strike to the northwest of where the Spider Glacier unit terminates (Figure 2). Swakane Gneiss is dominantly quartz-plagioclase-biotite-muscovite \pm garnet gneiss, with minor hornblende-garnet gneiss, and rare amphibolite, meta-peridotite, and quartzite (Cater, 1982).

The protolith of the Swakane Gneiss was likely deposited in a fore-arc basin at ca. 93-81 Ma and either underplated or thrust beneath the arc ca. $80 \mathrm{Ma}$ (Sauer et al., 2019). The Gneiss was metamorphosed at peak conditions of $640-750{ }^{\circ} \mathrm{C}$ at $9-12 \mathrm{kbar}$ (Valley et al., 2003; Gatewood and Stowell, 2012) between 75-63 Ma (Gordon et al., 2017). Leucotonalite intrusions and partial melt crystallized within the Gneiss between $78-68$ Ma (U-Pb zircon; Matzel et al., 2004; Gordon et al., 2017) and by 48 Ma part of the Gneiss served as the basement for the Eocene Chumstick basin (Tabor et al., 1987; 1989; Eddy et al., 2016). 


\section{METHODS}

Geologic mapping occurred in the summers of 2017 and 2018, for 7 weeks and 1 week, respectively. Mapping occurred in four field areas: the Spider Glacier area; Holden Village area; Rock Creek area; and Carne Mountain area (Figure 3). Field work focused on exposures of the Spider Glacier unit in the Spider Glacier area, and exposures of Holden assemblage rocks in the three other areas. During the summer of 2017, the Holden Village, Rock Creek, and Carne Mountain areas were mapped at 1:24,000 with United States Geological Survey (USGS) topographic quadrangles, and the Spider Glacier unit was mapped at 1:12,000 with the same quadrangle enlarged by $200 \%$. In the summer of 2018, part of the Spider Glacier area was mapped at a 1:5,000 scale with a base map constructed in ArcMap 10.

Fifty-six thin sections were collected and analyzed from the Spider Glacier unit, Holden assemblage, and Swakane Gneiss and used to characterize the rock types. Billets were cut at San Jose State University; most were cut parallel to lineation and perpendicular to foliation.

In order to quantify quartz deformation, mineral orientations were measured in three polished thin sections at University of Nevada, Reno (UNR). A final polish was added to the thin sections at UNR using a Buehler Vibromet 2 vibratory polisher at $10 \%$ power for 6 hours. The analyses used an Oxford NordlysMax ${ }^{2}$ electron backscatter diffraction (EBSD) camera in a JSM-7100FT Field Emission Scanning Electron Microscope (FESEM). Within the FESEM, the samples were oriented with the X-axis along the long edge of the thin section, parallel to lineation, and the Z-axis along the short edge, 
perpendicular to foliation. Post-processing of the analyses used Channel 5 software (Appendix 1). Mineral grain orientation maps and pole figures were generated using the Tango and Mambo modules, respectively (Appendix 1).

Zircon grains were separated from three rock samples in order to date the samples. Zircon separation occurred at SJSU and UNR in the spring and summer of 2018; refer to Appendices 2 and 3 for respective procedures. Mounting, and imaging of the zircon grains occurred at UNR. Refer to Appendix 4 for mounting procedures. Prior to dating, zircon grains were imaged using a Deben panchromatic cathodoluminescence (CL) detector in a JSM-7100FT FESEM. The three zircon grain mounts were dated using laser ablation with an inductively-coupled plasma mass spectrometer (LA-ICP-MS) in the W.M. Keck Collaboratory at Oregon State University. The samples were ablated using a Photon Machines Analyte G2 $193 \mathrm{~nm}$ laser. A He carrier gas transported ablated material to a plasma torch, and a Thermo Xseries II Quadrupole mass spectrometer equipped with an ion counter was used for ICP-MS analysis. Data were processed with in-house timeresolved software. A summary of the general analytical procedures is described by Loewen and Kent (2012).

\section{LITHOLOGIES}

\section{Holden Assemblage}

Previous workers divided the Holden assemblage into three (Miller et al., 1994) or four (Cater and Crowder, 1967) subunits. I mapped three zones (Figure 4) like the subunits of Miller et al. (1994). The zones I mapped are the heterogeneous zone, the calc-silicate gneiss zone and the leucogneiss zone. The heterogeneous zone covers the 
largest area and is dominantly biotite schist and gneiss, hornblende-biotite gneiss and quartz-bearing amphibolite, but also contains layers of leucogneiss, calc-silicate gneiss, quartzite and marble. The other two zones, the calc-silicate gneiss zone and the leucogneiss zone, both commonly include interlayers of biotite schist, biotite gneiss and quartz-bearing amphibolite, but layers of leucocratic gneiss and calc-silicate gneiss are more abundant, respectively, than in the heterogeneous zone. The heterogeneous zone dominates the western part of the Holden Village area (Figure 4) and the northwestern part of the Rock Creek area (Figure 5). The calc-silicate gneiss zone occurs in the central part of the Holden Village area and is absent in the Rock Creek area. Leucogneiss zones occur in the central Holden Village area and in the Rock Creek area. Field and thin section descriptions for the rock types that make up each of these zones are described below, in order from most abundant to least abundant. 


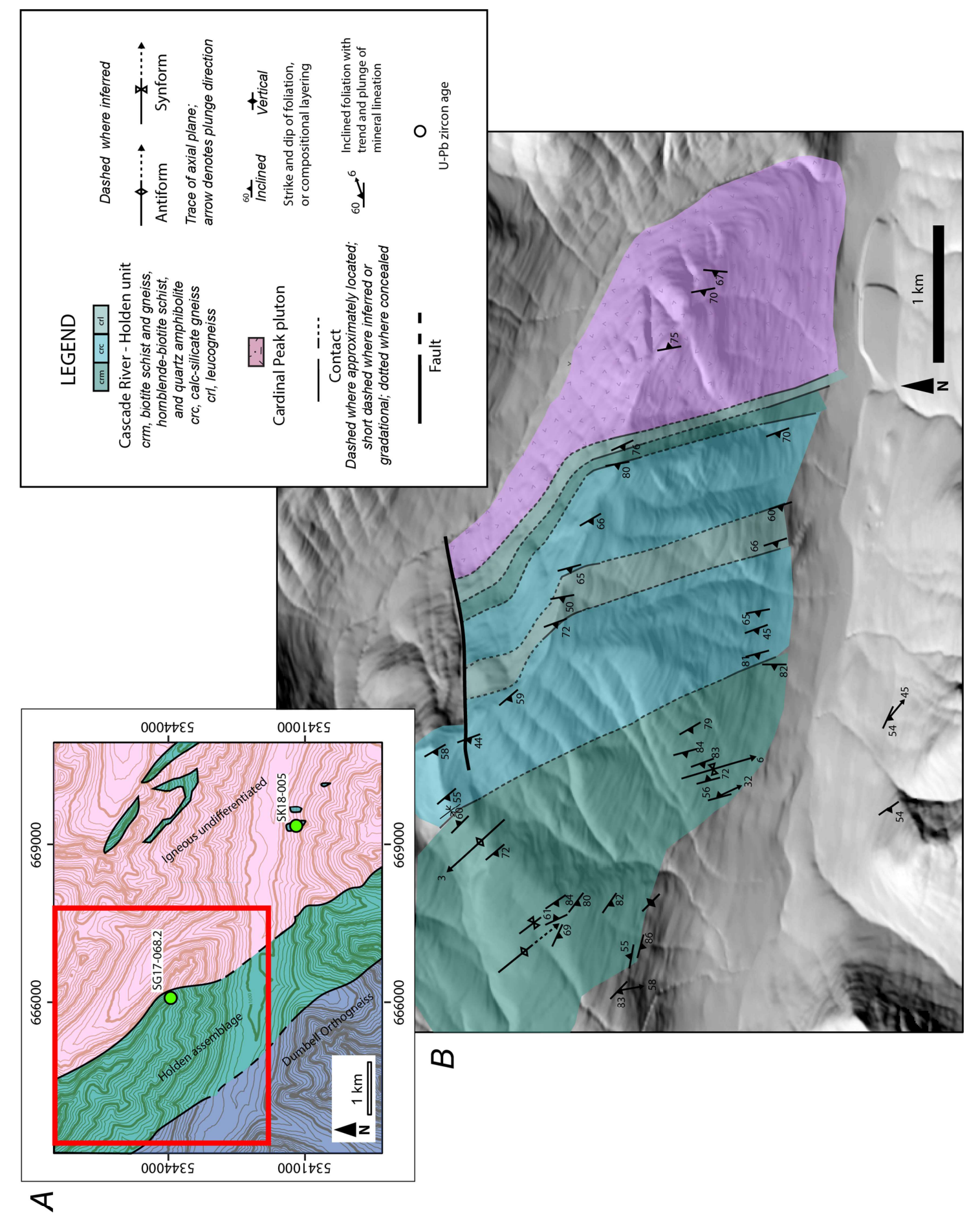

Figure 4. Geologic map of the Holden Village area. (A) Inset map of Holden Village area showing the location of $\mathrm{U}-\mathrm{Pb}$ zircon ages. Red box highlights the area of Figure 3B. (B) Geologic map of the Holden Village field area. 


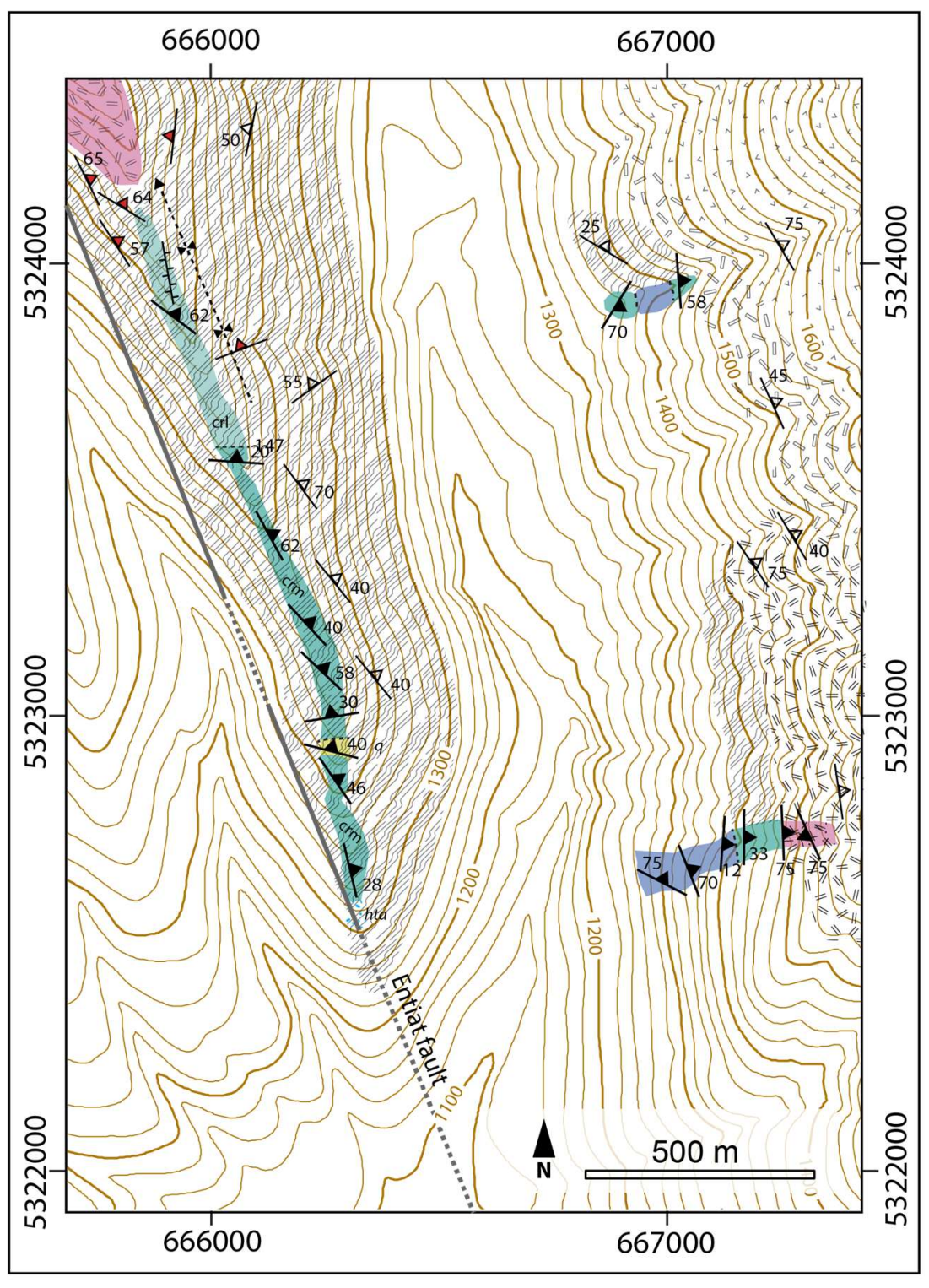

Figure 5. Geologic map of the Rock Creek area.

\section{\begin{tabular}{|l|l|l|l|}
\hline $\mathrm{crm}$ & $\mathrm{crl}$ & $\mathrm{crc}$ & $q$ \\
\hline
\end{tabular}}

Cascade River - Holden unit $\mathrm{crm}$, biotite schist and gneiss, hornblende-biotite schist, and quartz amphibolite crl, leucogneiss crc, calc-silicates
q, quartzite

hh, biotite gneiss, hornblende biotite gneiss sfj, Seven-Fingered Jack pluton

$j c$, contact zone
Trm, Rampart Mountain pluton

\section{Dumbell Orthogneiss} ahg, hornblende tonalite, diorite

From Cater and Crowder (1967)

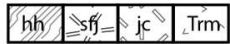

\section{Trend of marble beds} $\perp$

Contact

Dashed where approximately located; short dashed where inferred or gradational;

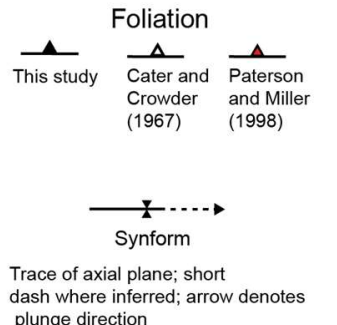




\section{Amphibolite}

Quartz-bearing amphibolite consists of diffuse 0.025-0.12-mm-thick layers of alternating composition and grain size. Foliation is continuous and defined by the layering, and the elongate hornblende and plagioclase grains. The color ranges from black to dark grey with local $\leq 1 \mathrm{~mm}$-thick quartz layers. Hornblende abundance in the layers ranges from $50->90 \%$. In thin section, amphibolite contains hornblende $(60 \%)$, plagioclase $(20 \%)$, quartz (10\%), and minor epidote. Hornblende is $0.25 \mathrm{~mm}$ to $3 \mathrm{~mm}$ in length and is largest in hornblende-rich layers. Plagioclase is polygonal or slightly elongate and ranges from $0.05-1.5 \mathrm{~mm}$ in length; it is largest in plagioclase-dominated layers. Quartz is polygonal, $0.25-3 \mathrm{~mm}$ in length, and occurs in elongate aggregates.

\section{Biotite Gneiss}

Biotite gneiss is fine grained; the mineral grains range from $0.25-0.75 \mathrm{~mm}$ in length. Foliation is defined by textural and compositional layering, aligned micas and opaque minerals, and shape preferred orientation of quartz and plagioclase grains. Some compositional layers are boudinaged and display pinch-and-swell structures. Freshly broken surfaces are grey in color, but weather to black with white laminations. Based on two thin sections, the gneiss is composed of quartz and plagioclase (45-90\%), biotite (10-40\%), muscovite $(0-5 \%)$, allanite $(0-5 \%)$, and minor clinozoisite and opaque minerals $(<5 \%)$. Biotite and muscovite are $0.1-0.2 \mathrm{~mm}$ in length and idioblastic. Both are weakly aligned. Clinozoisite is xenoblastic, occurs in biotite-rich layers, and has allanite and quartz inclusions and resorption textures. 


\section{Hornblende Gneiss}

Hornblende gneiss consists of $1 \mathrm{~mm}-15 \mathrm{~cm}$-thick gradational and discreet layers of varying grain size and hornblende abundance. Foliation is defined by compositional layering and a strong shape-preferred orientation of mineral grains. One thin section

consists of hornblende (60\%), plagioclase (35\%), quartz (5\%), and accessory clinozoisite, and titanite. Hornblende is $0.25-2 \mathrm{~mm}$ in length and elongate parallel to foliation. Hornblende transitions from subidioblastic to idioblastic with increasing grain size. Plagioclase occurs as subequigranular and polygonal grains, and forms symmetrical and asymmetrical porphyroclasts. Plagioclase ranges from $0.025-0.12 \mathrm{~mm}$ in length. Sparse interstitial quartz has subgrains. Quartz also occurs in a $0.25-1 \mathrm{~mm}$-wide and $6.25 \mathrm{~mm}$ long ribbon with $0.75 \mathrm{~mm}$-long subgrains. Clinozoisite has two forms, as either $\leq 1.5$ mm-long, acicular to rectangular idioblastic laths, or $<1 \mathrm{~mm}$-long, irregularly shaped grains.

\section{Calc-silicate Gneiss}

The primary assemblage of the calc-silicate gneiss is quartz, plagioclase, diopside, biotite and muscovite with accessory titanite and tourmaline, but it also contains $5 \mathrm{~cm}$-to1-m-thick interlayers which range from hornblende-rich and medium-grained, to hornblende-poor and fine-grained. Foliation is defined by compositional layering, elongate lenses of quartz, plagioclase and epidote, and aligned mica. Quartz is $0.25-0.5$ $\mathrm{mm}$ in length on average, but grain size varies modally throughout $\mathrm{mm}$-scale layers. Plagioclase is generally $0.25-0.5 \mathrm{~mm}$ in length, subidioblastic and commonly normally zoned. In some layers, actinolite forms pseudomorphs of diopside. Biotite and 
muscovite occur as $0.05-0.5-\mathrm{mm}-$ long, xenoblastic grains oriented parallel to foliation, and $0.25-0.35-\mathrm{mm}$-long idioblastic grains which are not aligned. Xenoblastic mica grains are undulose and strongly bent. In contrast, idioblastic mica grains are undulose but not strongly bent, suggesting they recrystallized after deformation ceased.

Tourmaline is pale yellow to brown with long axes parallel to foliation. Garnets occur locally and are 3-5 $\mathrm{mm}$ in diameter. Epidote forms $\mathrm{cm}$-scale lenses and 1-3 mm-thick bands.

\section{Leucogneiss}

In the Holden Village area, cm- to m-scale layers of leucogneiss are intercalated with calc-silicate gneiss, hornblende gneiss and amphibolite. The leucogneiss is locally difficult to distinguish from light-colored calc-silicate gneiss. In the leucogneiss, foliation is defined by quartz ribbons, elongate plagioclase lensoids, and aligned mafic minerals. On the basis of four thin sections, the leucogneiss consists of plagioclase (40-50\%), quartz $(40-50 \%)$, biotite $(5 \%)$, hornblende $(<5 \%)$, and muscovite $(0-<1 \%)$. Plagioclase is dominantly xenoblastic and $0.25-0.8 \mathrm{~mm}$ in length. Plagioclase is commonly lensoidal and displays normal and oscillatory zoning in two of four samples. Quartz composes ribbons and elongate aggregates of $0.25 \mathrm{~mm}-0.75 \mathrm{~mm}$-long grains. Biotite occurs in elongate $(<0.1 \mathrm{~mm}$-wide, $>2 \mathrm{~mm}$-long $)$ clusters of deformed grains, and in subidioblastic, lensoidal clusters with hornblende. Garnet occurs as $\sim 2 \mathrm{~mm}$-long clusters, which are aligned parallel to foliation. Epidote is retrogressive.

\section{Quartzite}

Quartzite comprises $<1 \%$ of the Holden assemblage, and occurs as $<50$-cm-thick 
layers in the Holden Village and Rock Creek areas. In one thin section from the Holden Village area, the quartzite contains quartz (85-95\%), undetermined amphibole (5\%), and epidote (2\%). Quartz is seriate and interlobate to subpolygonal. The largest grains are 3 $\mathrm{mm}$ in length and have $\sim 3: 1$ aspect ratios. The smallest grains are $<0.05 \mathrm{~mm}$ in length and mantle larger grains. Amphibole is subidioblastic and occurs in $0.5-1.5 \mathrm{~mm}$-long lensoidal aggregates. Epidote is a secondary phase.

\section{Marble}

Marble composes $<1 \%$ of the Holden assemblage, and occurs as $\mathrm{cm}$-scale layers in the Holden Village and Rock Creek areas. At two locations, the fine-grained marble forms 1-3-m-thick layers and in the Holden Village area, the layer contains $\mathrm{cm}$-scale boudins of amphibolite.

\section{Spider Glacier Unit}

The Spider Glacier unit is exposed in the Spider Glacier study area and probably extends $\sim 9 \mathrm{~km}$ to the south and $\sim 1 \mathrm{~km}$ to the north of the area. To the south it is terminated by the Entiat fault, and to the north it is truncated by the Cloudy Pass batholith (Figures 3 and 6) (Cater and Crowder, 1967).

Mapping delineated six metamorphic rock types within the Spider Glacier unit (Figure 7A). Hornblende-biotite gneiss is most abundant, and contains $\mathrm{cm}$ - to several $\mathrm{m}$ thick lenses and discontinuous interlayers of the other five rock types (Figure 7A). Hornblende gneiss forms at least three 1-to-10s-of-m-thick layers. Biotite gneiss forms 1 $\mathrm{cm}$ - to 10s-of-m-thick layers and is spatially associated with leucotonalite. Micaceous quartzite is not mapped as a separate unit, but locally composes $>40 \%$ of the rock in 
some areas (denoted with "q") (Figure 7A). Centimeter-to-m-scale lenses of metaperidotite make up $<1 \%$ of the Spider Glacier unit.

The metamorphic rock units occur with igneous material as mostly stromatic, and rarely netted metatexite migmatite. Diatexite migmatite occurs at one location. Though migmatite occurs in all the above-mentioned metamorphic rock units, it is most abundant in and adjacent to biotite gneiss and is not spatially associated with geologic structures. Boysun (2004) used textures in the adjacent Swakane Gneiss to argue that partial melt within the Gniess was locally derived. Boysun (2004), however, examined the Spider Glacier unit only briefly as part of her study of the Swakane Gneiss. She referred to the Spider Glacier unit as migmatitic gneiss. 

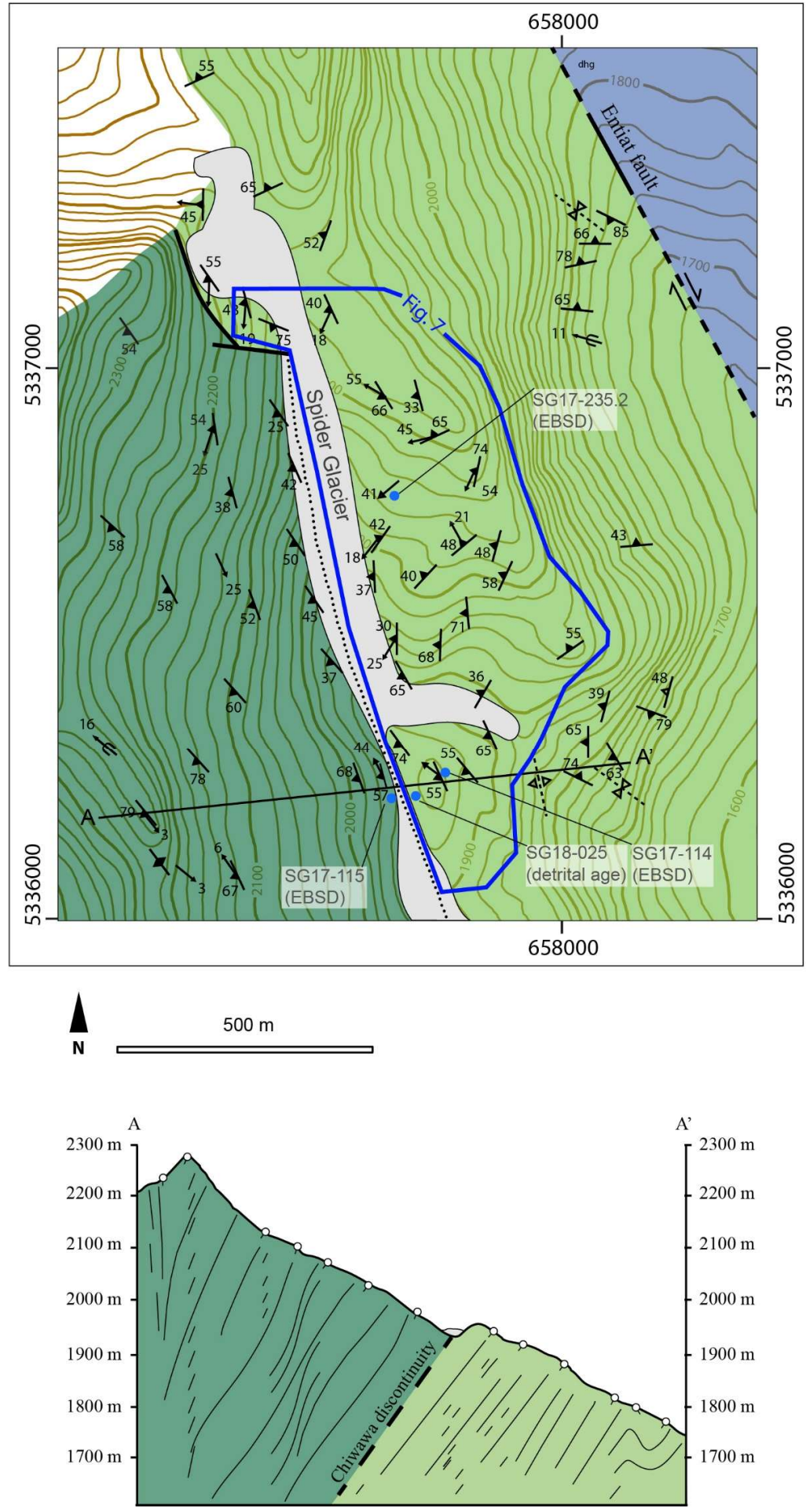

\section{UNITS}

Quaternary cover

Spider Glacier unit

Swakane Biotite Gneiss

Dumbell Orthogneiss

MAP SYMBOLS

Contact

Dashed where approximately located; short dashed where inferred or gradational; dotted where concealed

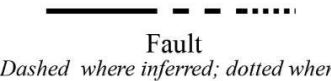

Dashed where inferred; dotted where concealed

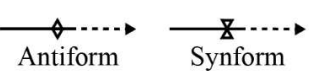

Showing trace of axial plane; short dash where inferred; arrow denotes plunge direction

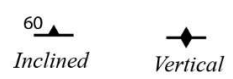

Strike and dip of foliation, or compositional layering

$$
\longrightarrow 10
$$

Bearing and plunge of mineral lineation

\section{0}

Inclined foliation with trend and plunge of mineral lineation

Figure 6. Geologic map of the Spider Glacier area. Sampling locations for EBSD and detrital zircon dating are shown. Contours are in meters. Blue line marks the boundary of detailed mapping shown in Figure 7A. 


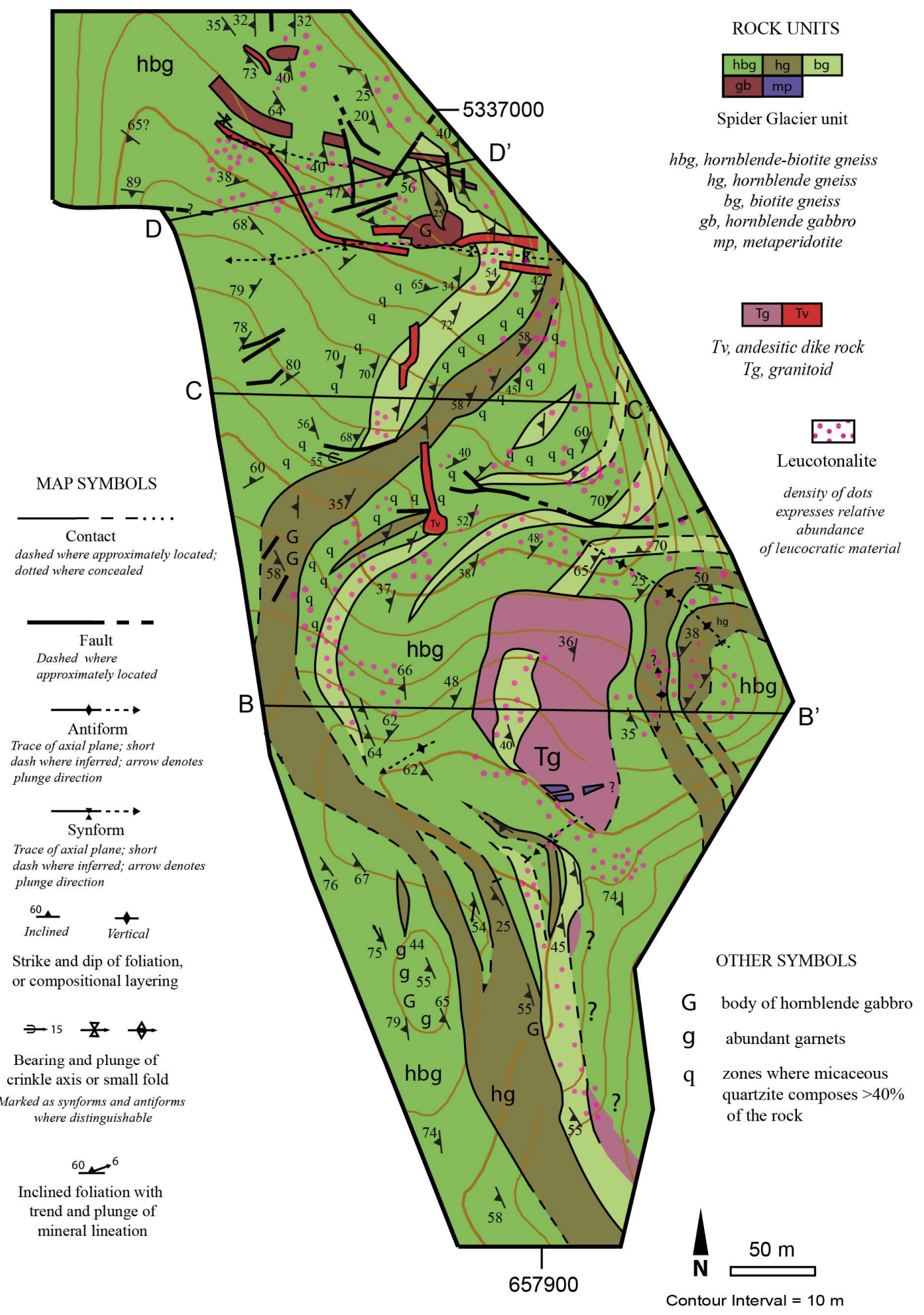

Figure 7A. Detailed geologic map of the Spider Glacier area. 

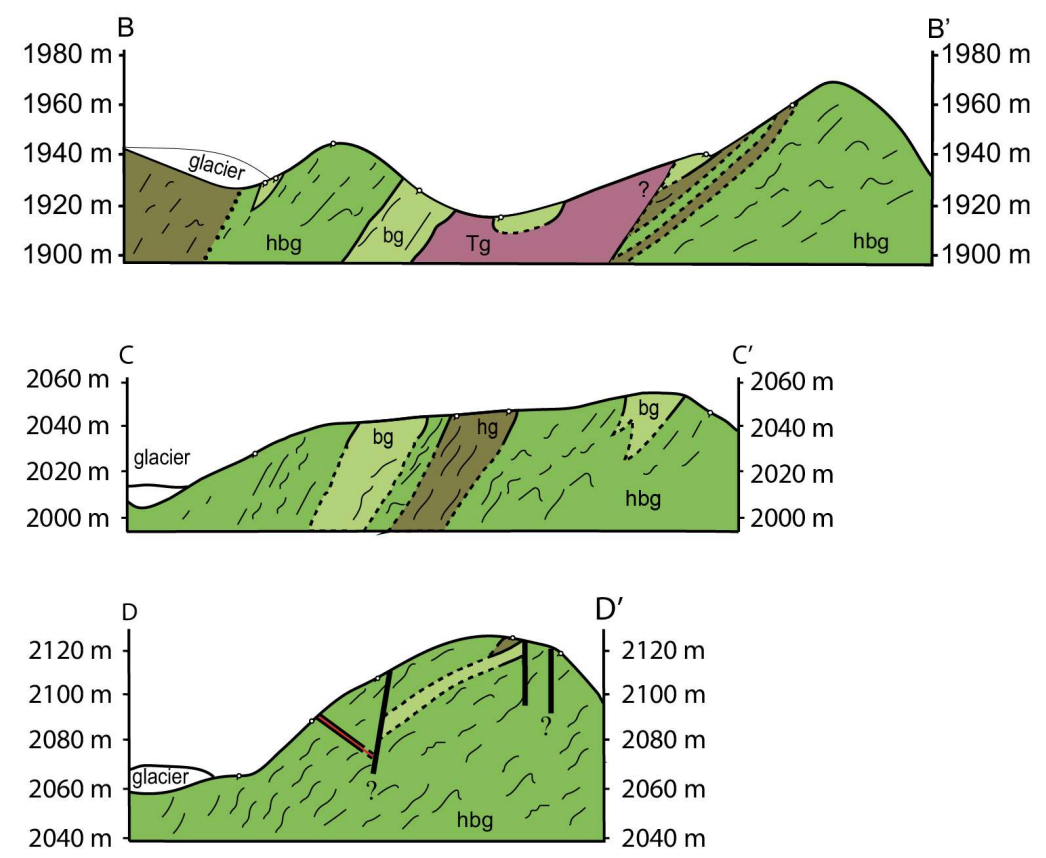

Figure 7B. Cross sections through the area shown on Figure 7A.

\section{Hornblende-biotite Gneiss}

Hornblende-biotite gneiss in the Spider Glacier unit is medium-grained and greybrown with mm-scale layers of quartzo-feldspathic material (Figure 8). Based on six thin sections, the hornblende-biotite gneiss consists of plagioclase, quartz, hornblende, biotite, and minor titanite, epidote, clinozoisite, apatite, and opaque minerals; garnet occurs in some samples. Foliation is defined by a shape preferred orientation of quartz, plagioclase, hornblende, and biotite grains, and mm-scale layering of quartzo-feldspathic and mafic layers. Plagioclase composes $20-40 \%$ of the gneiss and ranges from $\mathrm{An}_{15}-$ $\mathrm{An}_{45}$. It is $0.25-1.5 \mathrm{~mm}$-long, forms either subidioblastic grains or foliation-parallel lenticular grains. Plagioclase mosaics are present in one sample, suggesting medium-tohigh-temperature recrystallization. Quartz composes $10-30 \%$ of the gneiss and occurs 


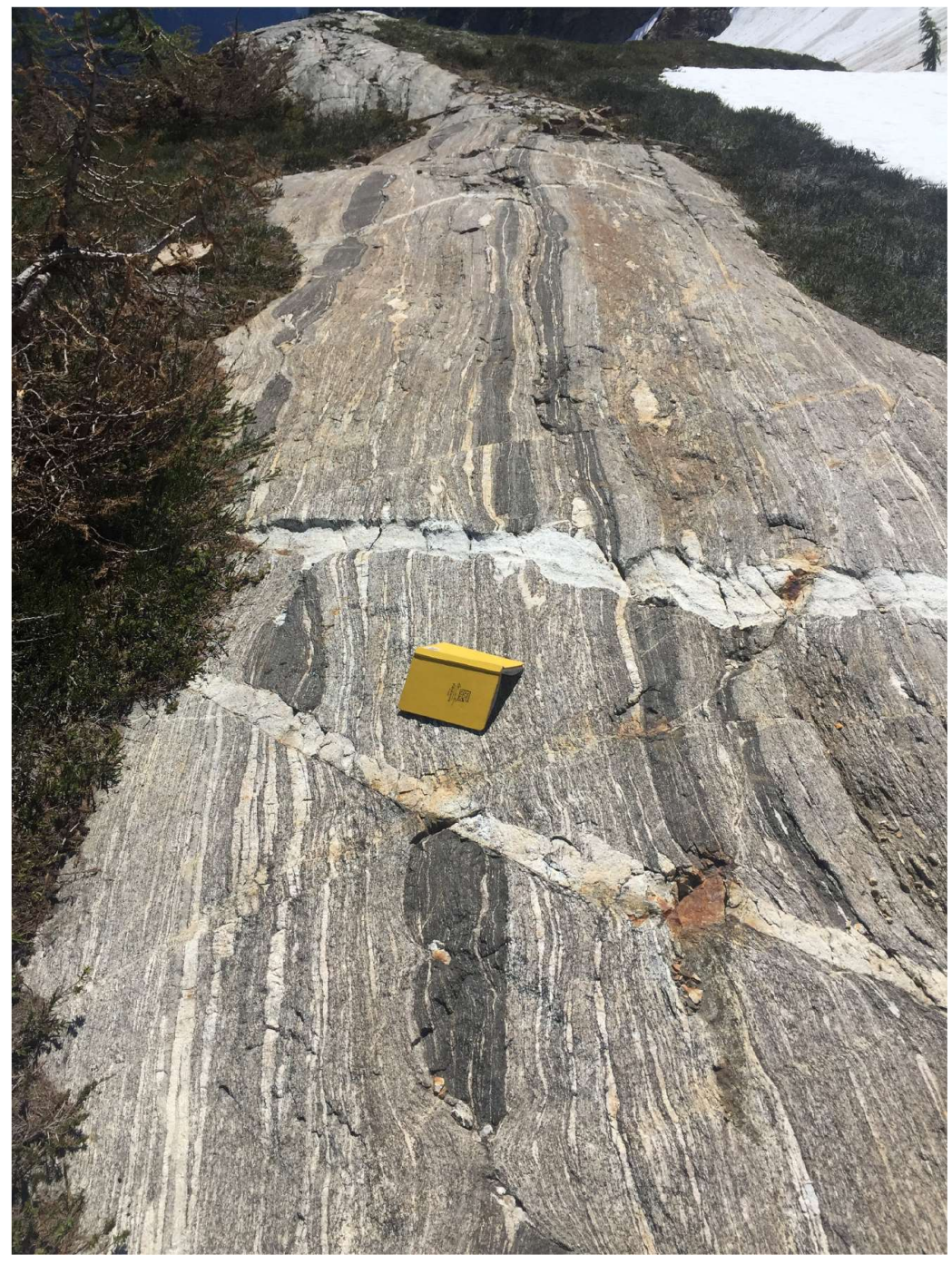

Figure 8. Photograph of hornblende-biotite gneiss of the Spider Glacier unit. Concordant layers of leucotonalite range from $<1-3 \mathrm{~cm}$ in thickness. Three $6-10 \mathrm{~cm}-$ thick interlayers of hornblende gneiss are boudinaged. Notebook is $6 \mathrm{~cm}$ long. 
as: subpolygonal and subequigranular grains in elongate, foliation-parallel aggregates or ribbons; elongate grains with aspect ratios of 2:1; and as rounded quartz inclusions in plagioclase and hornblende.

Hornblende-biotite gneiss generally contains $15-30 \%$ hornblende, though hornblende makes up $50-80 \%$ of some local layers. Hornblende grains are $0.1-1.75-\mathrm{mm}$-long, foliation-parallel grains. They contain rounded quartz or subidioblastic biotite inclusions. Some hornblende is heavily altered, mostly to biotite or titanite, and locally to white mica. Biotite abundance varies from $10-35 \%$ in the gneissic layers and occurs as two textural types. One type is $0.25-0.75 \mathrm{~mm}$ in length and $0.15-0.6 \mathrm{~mm}$ in width, is commonly lenticular, and occurs in aggregates. The second type is smaller, $0.1-0.3 \mathrm{~mm}$ in length and $0.1 \mathrm{~mm}$ in width, xenoblastic, and occurs as solitary grains. Garnet occurs in five of six samples, ranges from 1-3 mm across, is weakly elongate, and has quartz, epidote, and biotite inclusions. Inclusions display either no alignment, or a weak alignment subparallel to foliation. Foliation wraps garnets. Partial retrogression of garnet to biotite is common.

\section{Hornblende Gneiss}

Hornblende gneiss is present throughout the field area interlayered with hornblendebiotite gneiss, biotite gneiss and micaceous quartzite. The hornblende gneiss displays 1 $\mathrm{mm}-8$-cm-thick layering, wherein mineral abundances grade from $\sim 60-80 \%$ plagioclase to $>90 \%$ hornblende. Grain size varies from $<1 \mathrm{~mm}$ to $3 \mathrm{~mm}$.

Hornblende gneiss contains hornblende (30-50\%), plagioclase (15-30\%), and quartz $(5-15 \%)$, with accessory titanite and garnet. Hornblende has a bimodal grain size, with 
coarse (1.5-3 $\mathrm{mm}$ in length) and fine $(0.25-0.75 \mathrm{~mm}$ in length) grains. The coarse grains occur with titanite. The fine grains occur in mosaics with plagioclase. Plagioclase is subidioblastic, and generally $0.25-0.75 \mathrm{~mm}$ in length, and interlocks with hornblende or other plagioclase grains. Five out of six samples contain garnet, which is typically $1-3$ $\mathrm{mm}$ in diameter, but may be as large as $1 \mathrm{~cm}$. Foliation wraps garnet. Retrogression of garnet to biotite is common. Other retrograde phases in the gneiss include: white mica, which commonly replaces plagioclase; undetermined colorless amphibole, which is either coarse-grained $(5-10 \mathrm{~mm})$, or fine-grained $(<0.05 \mathrm{~mm})$ and feathery; and chlorite.

\section{Micaceous Quartzite}

Micaceous quartzite is medium- to dark-bluish grey, or pale-white, and has a characteristic vitreous luster. It commonly forms interlayers in hornblende gneiss in the northern half of the Spider Glacier study area (Figure 9) and is interlayered with hornblende-biotite gneiss in the southern part of the area. Foliation is defined by a parallel alignment of elongate quartz grains and asymmetric mica grains. Two thin sections of micaceous quartzite contain $80-95 \%$ quartz, 5-20\% mica, minor, hornblende, apatite, and plagioclase (Figure 10). Mica is dominantly biotite, which locally comprises $>20 \%$ of the rock. One location contains foliation-wrapped garnet that is up to $\sim 7 \mathrm{~mm}$ in diameter. Other garnet is small $(<0.1 \mathrm{~mm})$, anhedral, and truncates foliation 


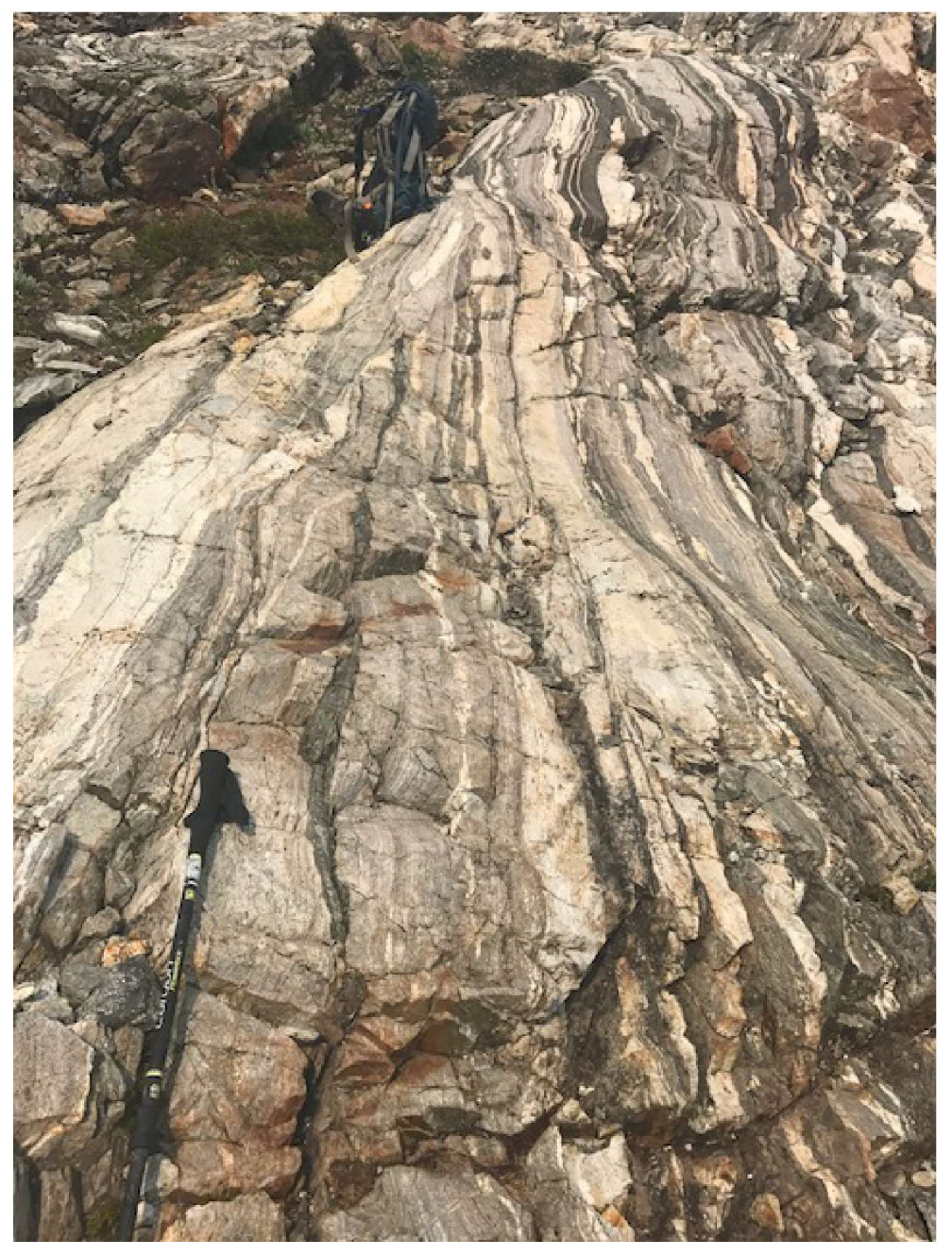

Figure 9. Photograph of micaceous quartzite of the Spider Glacier unit. The outcrop consists of interlayered micaceous quartzite, biotite gneiss, and hornblende gneiss. Handle of the hiking pole is $5 \mathrm{~cm}$. 


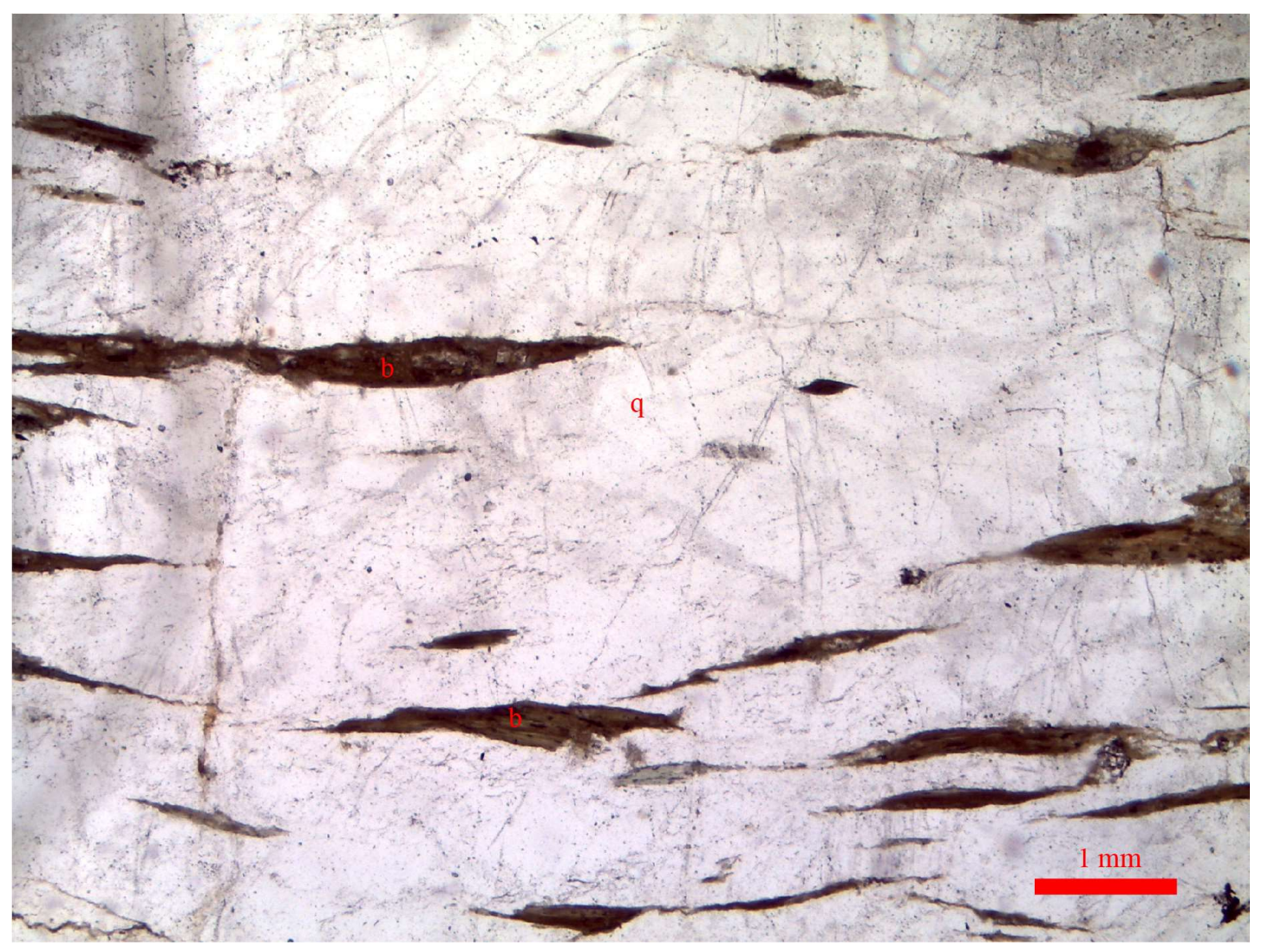

Figure 10. Photomicrograph of micaceous quartzite. Micaceous quartzite from the Spider Glacier unit. Quartz grains are marked with " $q$ ". Biotite grains are marked with " $b$ ".

\section{Biotite Gneiss}

Biotite gneiss occurs in at least five tens-of-meter-thick layers, and as centimeterscale-thick layers within hornblende gneiss and hornblende-biotite gneiss. Centimeterscale compositional layering within the gneiss is marked by changes in abundance of quartz, plagioclase, and mafic minerals (Figure 11). Grain size ranges from $<1 \mathrm{~mm}$ to 5

mm. A thin section of biotite gneiss contains plagioclase, quartz, biotite and accessory amphibole, clinozoisite, titanite, muscovite and opaque minerals. Plagioclase composes $\sim 50 \%$ of the gneiss, is $0.5-1.0 \mathrm{~mm}$ in length, and is subidioblastic with aspect ratios of 
1.5-1.3. Quartz makes up 15-25\% of the gneiss and forms $0.5-1.5 \mathrm{~mm}$-long lenses of either larger, up to 0.5 -mm-long grains, or smaller, $<0.05$-mm-long grains. Biotite and accessory minerals compose the remaining $10-15 \%$. Biotite is xenoblastic, elongate (aspect ratio of 2:1-5:1), bent, and undulose.

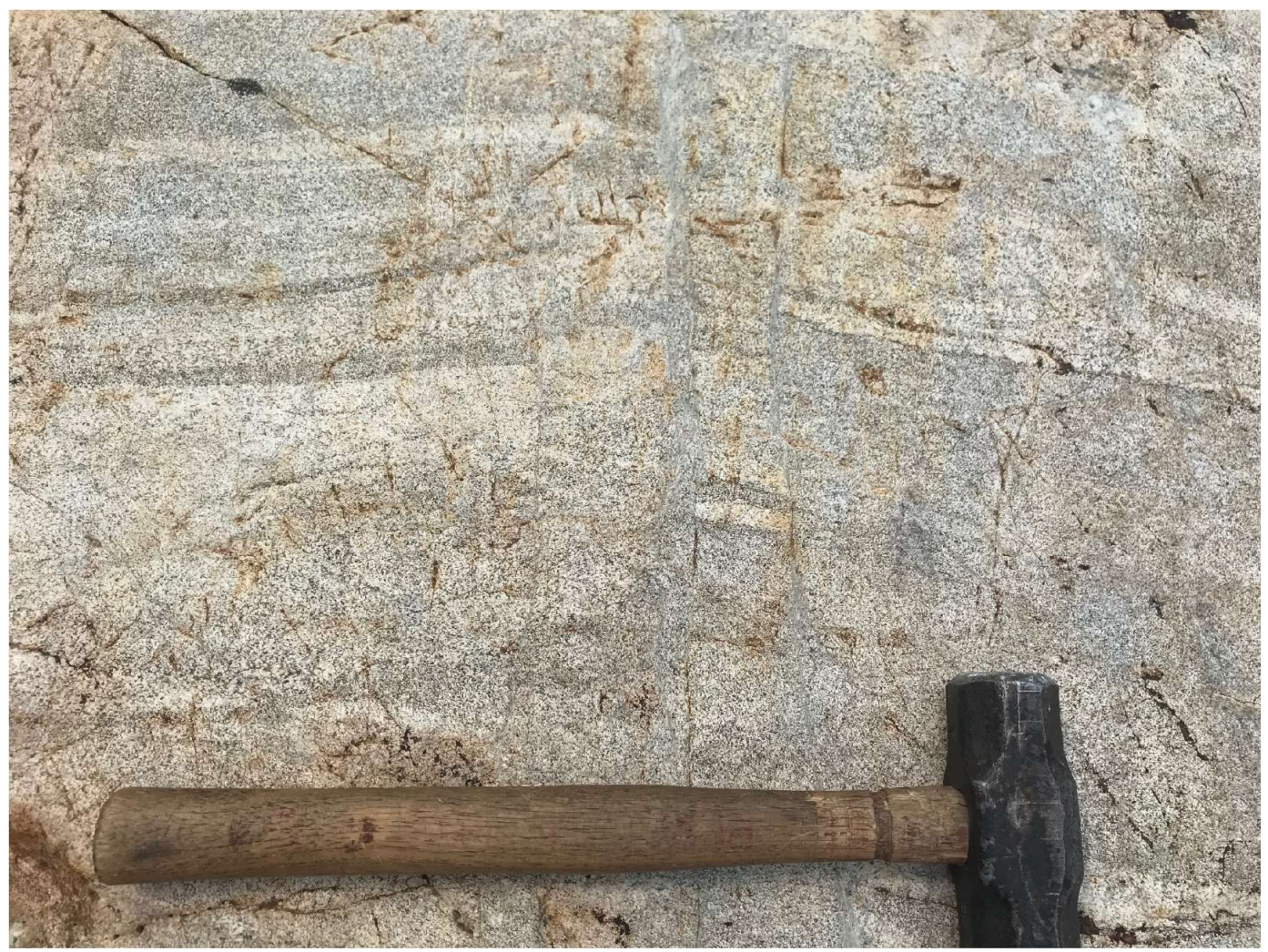

Figure 11. Photograph of biotite gneiss of the Spider Glacier unit. Note the light color and the compositional layers defined by different amounts of quartz and plagioclase. The layers are offset by small faults. Hammer is $40 \mathrm{~cm}$ in length. 


\section{Meta-peridotite}

Meta-peridotite lenses with aspect ratios ranging from 2:1 to $>20: 1$ compose $<1 \%$ of the Spider Glacier unit (Figure 12). Lenses are generally 5-15 $\mathrm{cm}$ in length, but are up to $1 \mathrm{~m}$ in length. Meta-peridotite varies from very-coarse-grained actinolite schist, to phlogopite-bearing tremolite-talc schist. No thin section was made of the actinolite schist. In two thin sections, talc makes up $\sim 60-90 \%$ of the meta-peridotite, is $<0.05-5$ mm-long, and subidioblastic to idioblastic. Tremolite makes up 5-40\% of the samples, occurring as highly elongate grains with aspect ratios of $\sim 7$, idioblastic laths and lenses surrounded by talc, and as clusters of $\sim 0.1 \mathrm{~mm}$-long grains. Biotite and chlorite each compose up to $5 \%$ of the rock. Chlorite is very-fine grained $(<0.05 \mathrm{~mm})$ and feathery.

\section{Igneous Intrusive Rocks}

Three igneous rock types intrude the Spider Glacier unit at a mappable scale. They are hornblende gabbro, leucocratic granitoid, and andesitic(?) dike rock. Map-scale hornblende gabbro includes one dike and one irregularly shaped body in the northern Spider Glacier study area (Figure 7A). Smaller bodies of gabbro are marked with "G" on Figure 7A. The gabbro also occurs within hornblende-biotite gneiss as ductily deformed $\mathrm{m}$-scale to $\mathrm{cm}$-scale lenses. In thin section, the hornblende gabbro consists of hornblende, plagioclase, and quartz, and accessory clinozoisite and opaque minerals. Hornblende composes $60-80 \%$ of the gabbro, and is $<1$ to $5 \mathrm{~mm}$ in length. Chlorite and titanite are alteration products. 


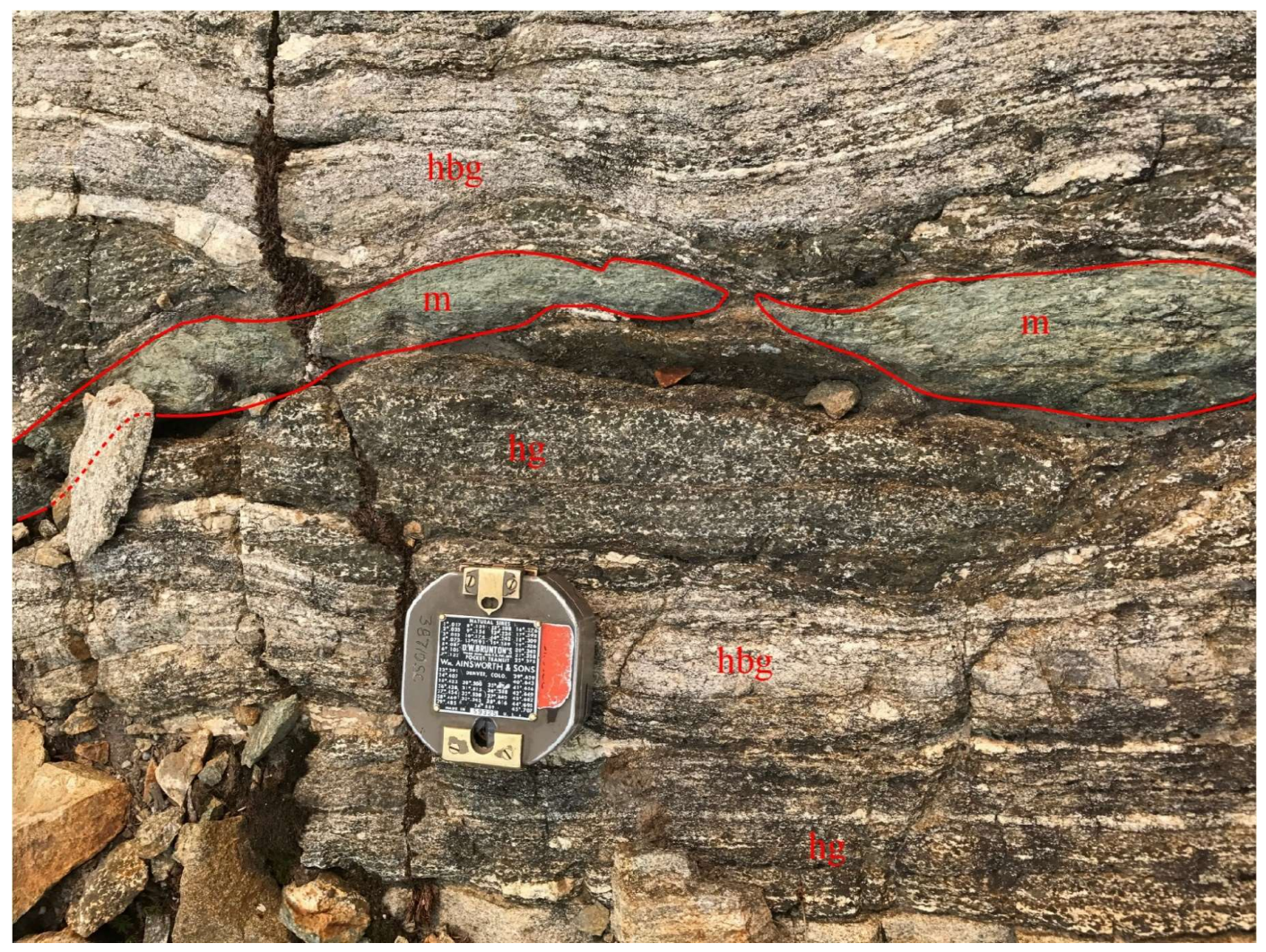

Figure 12. Photograph of meta-peridotite of the Spider Glacier unit. The meta-peridotite (m) lenses are elongate parallel to the layering with hornblende-biotite gneiss (hbg) and hornblende gneiss (hg). Brunton compass for scale.

Five generations of leucocratic granitoids intrude the Spider Glacier unit, and only leucotonalite occurs at a mappable scale, as a $\sim 50 \mathrm{~m}^{2}$ sill (Figure 7A). The other granitoids occur as dikes and are pegmatitic granitoid, biotite leucogranite, pegmatitic to medium-grained leucogranitoid, pegmatitic to medium-grained biotite-hornblende granitoid, and hornblende tonalite. The leucocratic granitoids generally lack foliation, but in rare cases had aligned mafic minerals.

Two andesitic dikes intrude the Spider Glacier unit. They are $1 \mathrm{~m}$-thick, and 100-200 m-long (Figure 7A). The andesitic dikes are undeformed. 


\section{Swakane Gneiss}

A small portion of the Swakane Gneiss was mapped in the Spider Glacier study area. The Gneiss is medium-grained and composed of quartz, plagioclase, and biotite with small amounts of chlorite, epidote, clinozoisite, and garnet. Foliation is defined by a shape preferred orientation of quartz, plagioclase and mica grains, and by $\sim 0.25 \mathrm{~mm}$ thick compositional layers with varying amounts of biotite.

In thin sections of 8 samples, quartz and plagioclase make up $60-80 \%$ of the Gneiss. Biotite composes $10-30 \%$ of the Gneiss, and muscovite ranges from $0-10 \%$. Plagioclase is idioblastic to subidioblastic, ranges from $0.125-1.5 \mathrm{~mm}$ in length, and commonly contains small, round quartz inclusions. Quartz is $0.025-1-\mathrm{mm}-$ long and is typically smaller than plagioclase. Quartz locally forms mosaics of very fine, $<0.025$-mm-across grains. Biotite occurs as coarse subidioblastic grains in $\sim 0.5 \mathrm{~mm}$-long clusters, which wrap quartz and plagioclase grains, and as xenoblastic, commonly bent, acicular grains which are generally $>1.375 \mathrm{~mm}$ in length and $<0.075 \mathrm{~mm}$ in width, and are commonly bent. Muscovite is in 4 of 8 samples, is idioblastic to subidioblastic, and generally $0.125-0.5 \mathrm{~mm}$ in length, but ranges up to $0.75 \mathrm{~mm}$ in length. Muscovite is typically bent and is commonly surrounded by biotite and chlorite. Sparse xenoblastic clinozoisite is commonly twinned and kinked. Garnet occurs in 3 of the 8 samples, and is wrapped by foliation suggesting it is pre- to syn-kinematic. Garnet ranges from $0.25-0.75 \mathrm{~mm}$ in diameter and commonly has internal fractures oriented subperpendicular to foliation and filled with mica. Chlorite alteration occurs in 6 of the 8 samples. 


\section{STRUCTURES}

The goal of mapping geologic structures was to understand the geologic histories of the Spider Glacier unit, Swakane Gneiss, and Holden assemblage. In general, the Spider Glacier unit and the Holden assemblage at Carne Mountain record a generation of moderately to steeply plunging folds that are absent in the Swakane Gneiss and the Holden assemblage in the Holden Village area.

\section{Spider Glacier Area}

In the Spider Glacier study area, a $\sim 4 \mathrm{~km}$-wide belt of Spider Glacier unit is separated from the Dumbell Orthogneiss to the northeast by the Entiat fault and the Swakane Gneiss to the southwest by the Chiwawa discontinuity (Figures 3 and 6). Deformation varies across the discontinuity. Southwest of the Chiwawa discontinuity, in the Swakane Gneiss, foliation is defined by elongate quartz and plagioclase grains, aligned biotite, and $\mathrm{cm}$-scale compositional layers with varying amounts of biotite and plagioclase. The foliation is stronger than lineation and consistently strikes southeast $\left(140-160^{\circ}\right)$. The foliation dips mostly $40-60^{\circ}$ southwest, and ranges from $25-70^{\circ}$ (Figure 13 ). The average attitude is $152^{\circ} / 49^{\circ} \mathrm{SW}$. Foliation intensity is consistent throughout the area. The foliation is axial planar to tight to isoclinal folds of cm-scale-thick felsic sheets in the Gneiss. Biotite defines shallow mineral lineations, most of which plunge 5-25 northwest and southeast (Figure 13). 


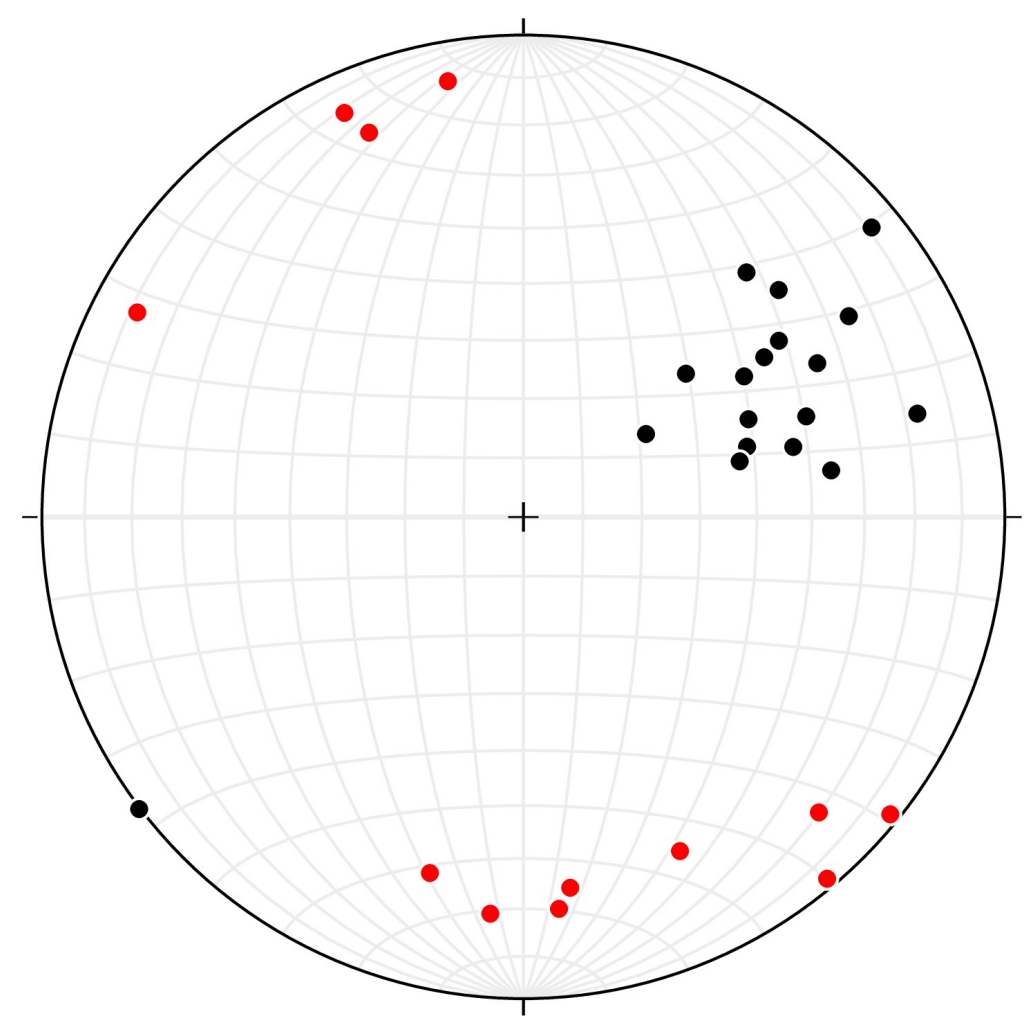

Figure 13. Foliations and mineral lineations in the Swakane Gneiss. Lower-hemisphere equal area stereographic projection. Poles to foliation $(n=18)$ are shown as black dots. Mineral lineation orientations $(n=12)$ are shown as red dots.

In the Spider Glacier unit, the foliation varies in orientation due to folding along west northwest- to west-southwest-plunging, 100s-of-m-wavelength folds (Figure 14).

Foliation strikes southeast to southwest and dips to the southwest and northwest. Most of the foliations dip between $25-70^{\circ}$, but dips range from $20-90^{\circ}$. In some cases, the dip changes along strike by as much as $45^{\circ}$ over $10 \mathrm{~m}$. Mineral lineations are defined by aligned biotite and hornblende. Lineations most commonly plunge $\sim 30^{\circ}$ to the south and northeast but have a wide range of orientations, plunging from $5-80^{\circ}$ to the northwest, west and southwest (Figure 15). This variability in lineation orientations strongly implies that the lineations have been folded. 


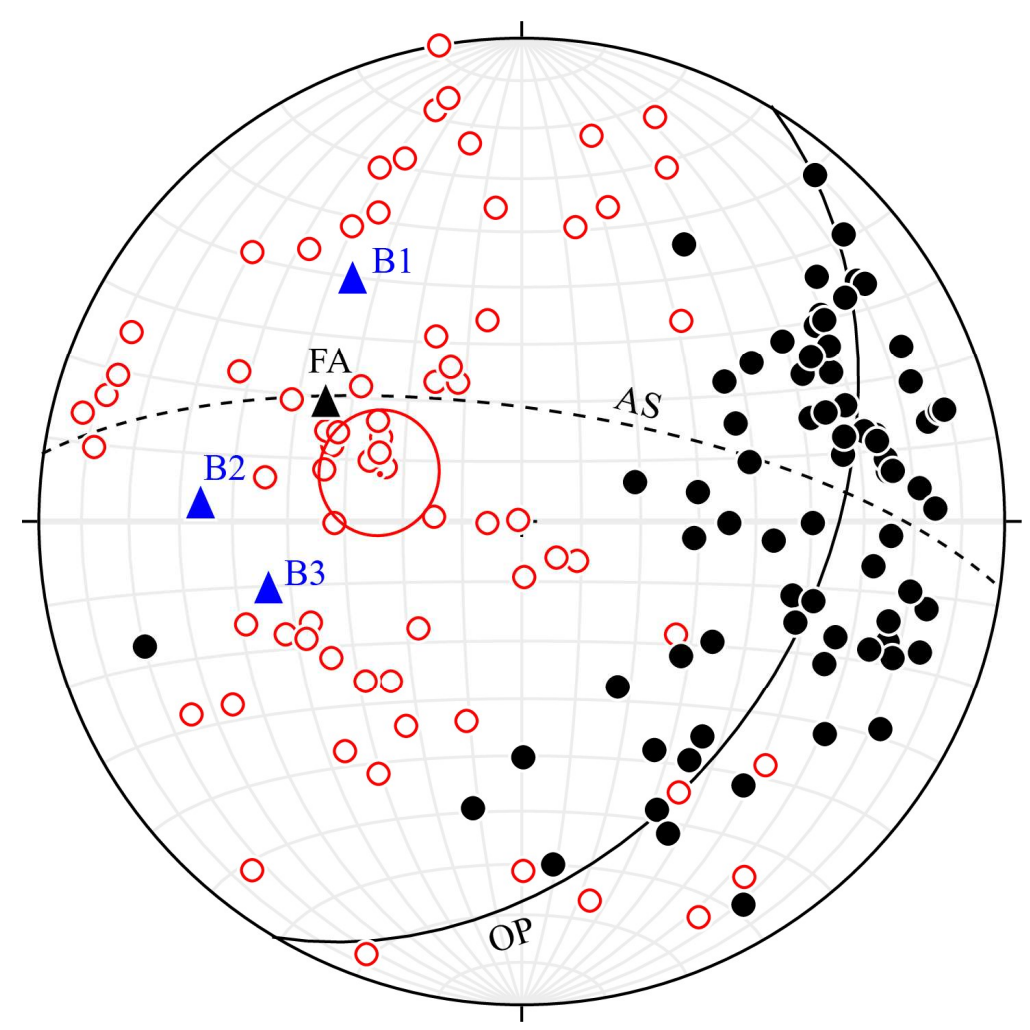

Figure 14. Poles to foliation and fold axes in the Spider Glacier unit. Lower-hemisphere equal area stereographic projection. Poles to foliation $(n=77)$ are shown as black dots. Fold axes $(n=85)$ are shown as red circles. Foliations define a girdle and an inferred fold with an orthogonal plane (OP) oriented $031^{\circ} / 39^{\circ} \mathrm{SE}$ (solid black line), a fold axis (FA) oriented $51^{\circ} / 301^{\circ}$ (black triangle), and an axial surface (AS) oriented $278^{\circ} / 71^{\circ} \mathrm{NE}$ (dotted line). The mean vector of fold axes is oriented $65^{\circ} / 290^{\circ}$ (not shown) with error shown as a large red circle. Map-scale folds B1, B2 and B3 are shown by blue triangles.

Foliations in the Spider Glacier unit $(\mathrm{n}=77)$ define a girdle with an axis plunging $51^{\circ}$ to the west-northwest $\left(301^{\circ}\right)$. The considerable scatter in points away from the girdle indicate non-cylindrical folding. The orientations of three map-scale folds were identified by inputting 4-5 local attitudes into Allmendinger's Stereonet 10 and calculating the orientation of fold axes and axial surfaces. The folds are referred to, from 
north to south, as folds B1, B2, and B3 (Figure 16). B1 is an upright open synform which plunges $34^{\circ}$ west $\left(273^{\circ}\right)$. B2 is an upright open antiform with an axis plunging $40^{\circ}$ to the northwest $\left(325^{\circ}\right) . \mathrm{B} 3$ is an upright open synform with an axis plunging $45^{\circ}$ to the southwest.

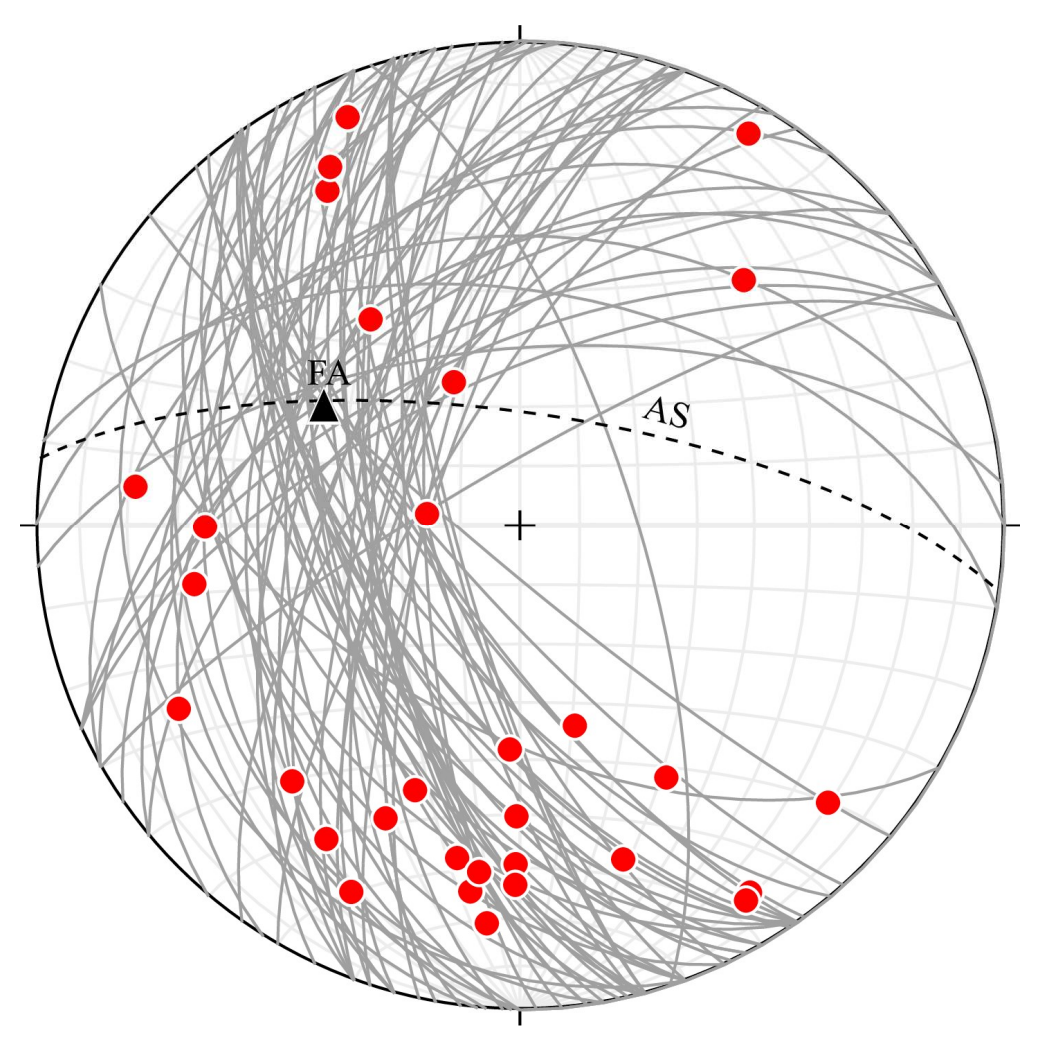

Figure 15. Foliations and mineral lineations in the Spider Glacier unit. Lowerhemisphere equal area stereographic projection. Mineral lineations $(\mathrm{n}=31)$ are shown as red dots. The fold axis (FA) for the combined foliations is oriented $51^{\circ} / 301^{\circ}$ (black triangle), determined from a cylindrical best fit calculation of foliation orientations in Almendinger's Stereonet 10. 


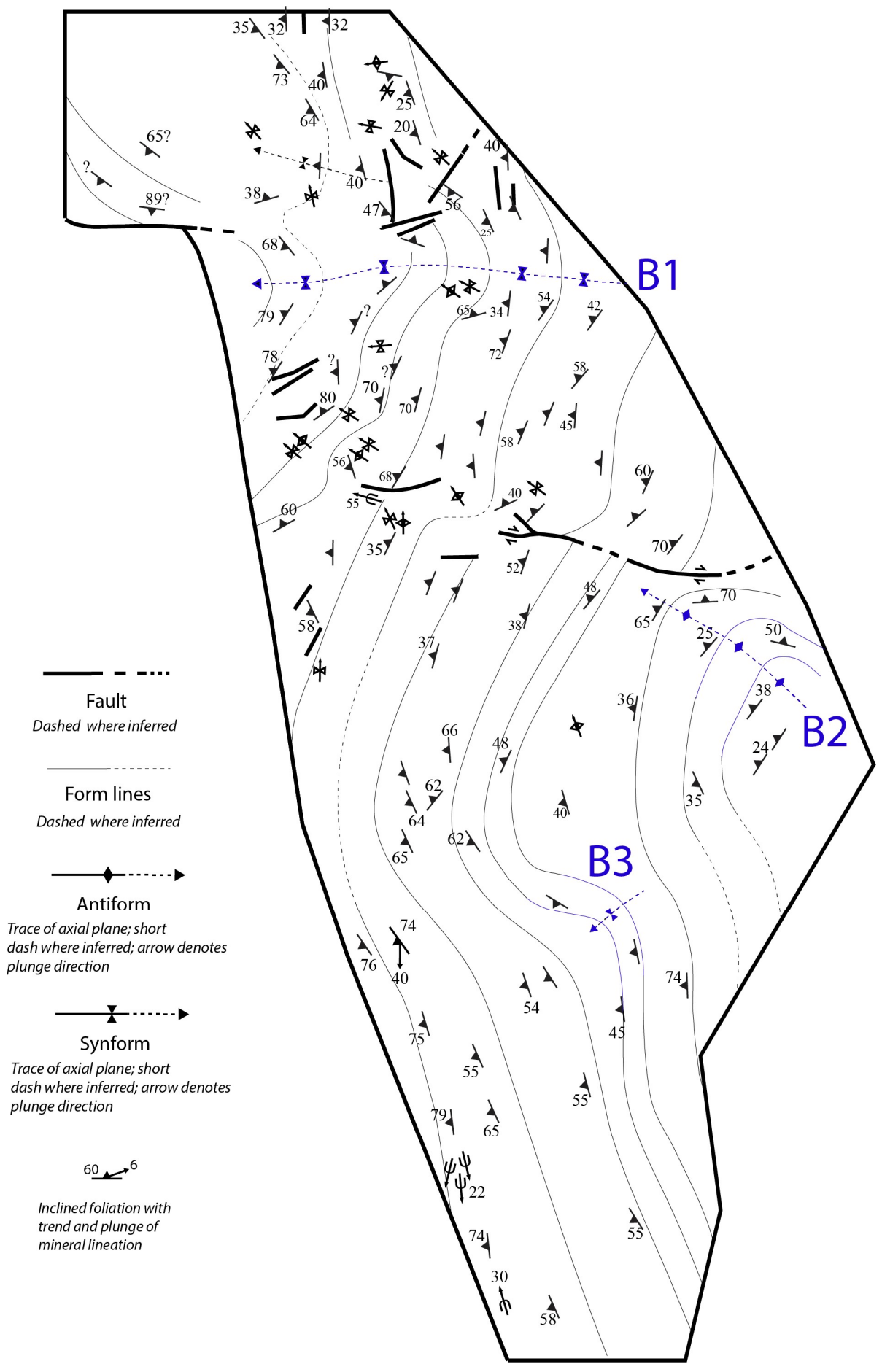

Figure 16. Structural map of the Spider Glacier area. Map-scale folds are defined by form lines, which indicate the approximate strike of foliation. Folds labelled B1, B2 and B3 are described in text. 
At least three generations of outcrop-scale folds occur in the Spider Glacier unit. The earliest folds $\left(F_{1}\right)$ fold foliation and felsic sheets tightly to isoclinally. $F_{1}$ folds have wavelengths of $1-10 \mathrm{~cm}$ and axial planes which are most commonly subparallel to the dominant foliation $\left(\mathrm{S}_{1}\right) . \mathrm{F}_{1}$ folds occur less commonly as upright crinkle folds in metaperidotite pods and hornblende-rich layers. $S_{1}$ and $F_{1}$ are folded by $10-\mathrm{cm}-$ to $2-\mathrm{m}-$ wavelength, horizontal to steeply plunging, upright to gently inclined, open to tight folds $\left(F_{2}\right) . F_{2}$ fold styles include chevron and kink folds (Figure 17). Leucocratic material intrudes at least one $F_{2}$ kink fold (Figure 17). In at least one area, $F_{2}$ is refolded by a subperpendicular $\mathrm{F}_{3}$ fold to produce type-I and type-III interference patterns (Figure 18). The mean orientation of all outcrop-scale hinge lines $\left(F_{1}+F_{2}\right)$ is $68^{\circ}, 285^{\circ}(n=80)$, which is broadly similar in orientation to the fold axis calculated from all foliations, $51^{\circ} / 301^{\circ}(\mathrm{n}=77)$, leading to the interpretation that at least some outcrop-scale folds are parasitic to map-scale folds. However, the orientations of map-scale folds B1, B2, and B3 differ from the average orientation of outcrop-scale folds, B2 and B3 are nearly at right angles to each other, and outcrop-scale fold axes have a very wide range of orientations that differ from the mean orientation. 


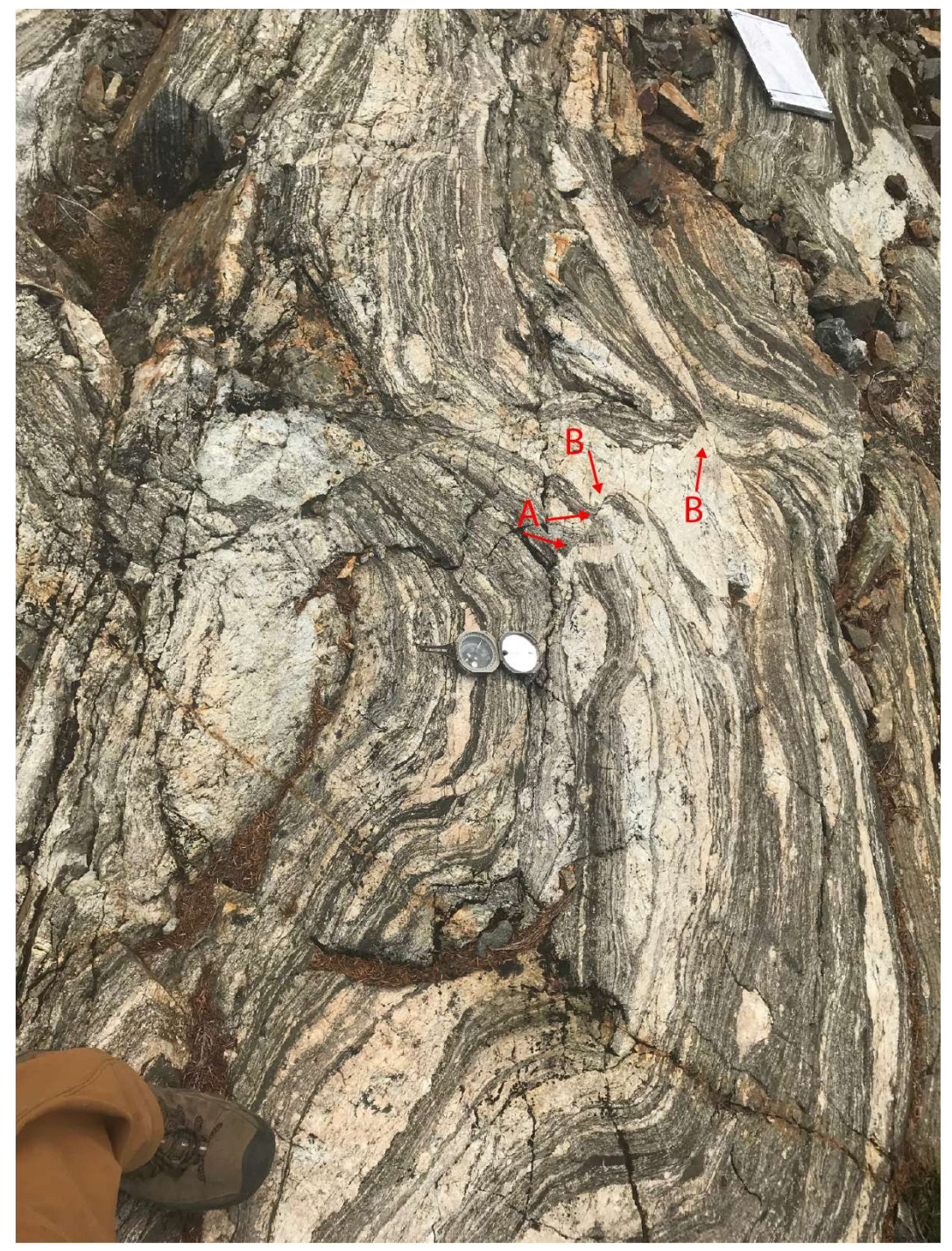

Figure 17. $F_{2}$ kink fold in hornblende-biotite gneiss. Trend of fold hinge line is oriented parallel to Brunton compass. Note there are two generations of leucotonalite; the first is offset by a fault (denoted with arrows labelled "A"). The second intruded along the fault plane (denoted with arrows labelled "B"). Most leucotonalite is concordant to foliation in hornblende-biotite gneiss. 


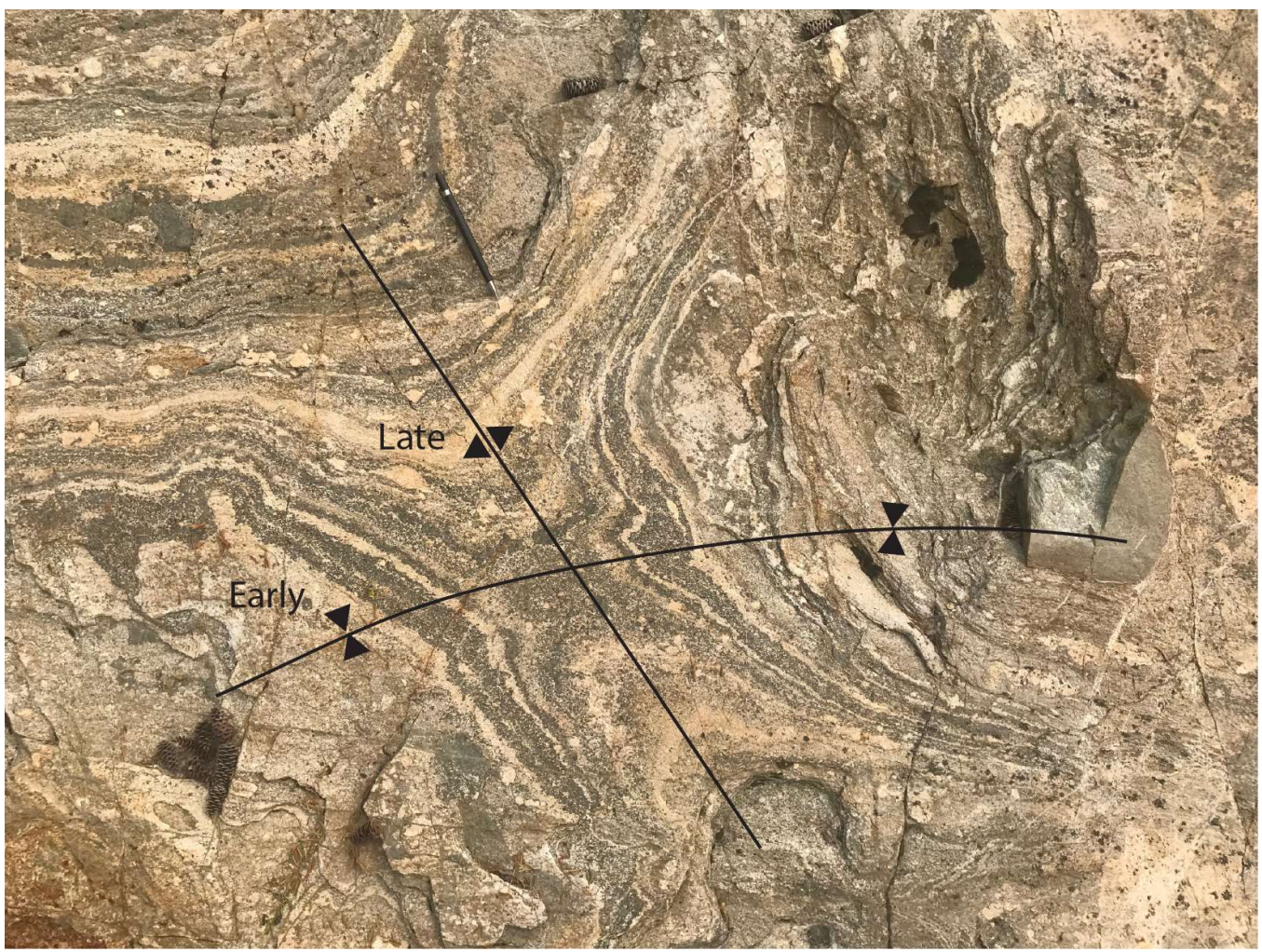

Figure 18. Type-III fold interference pattern in hornblende-biotite gneiss. Photo taken in the Spider Glacier unit, roughly $3 \mathrm{~m}$ from Chiwawa discontinuity. Approximate traces of axial surfaces for early and late folds are shown with black lines. Picture is roughly $1 \mathrm{~m}$ across.

Local faults (10-100 m offset) in the Spider Glacier area have variable orientations and displacements, and show no obvious patterns. Separation was measured along offset tonalitic and gabbroic sheets near fold B1 in the Spider Glacier area. Faults that offset sheets strike north, northeast, and east-northeast, and have steep dips (75-90 $)$ based on their straightness in map view. Other faults strike east-west and also have steep dips. One east-west-striking fault dextrally offsets compositional layers as determined from the apparent drag of layers. Another steep east-west trending $\left(110^{\circ} / 85^{\circ}\right.$ southwest $)$ fault truncates the Chiwawa discontinuity with apparent sinistral separation (Cater and Crowder, 1967). 
Two sets of smaller, outcrop-scale faults were distinguished. One set is reverse faults, which are spatially associated with outcrop-scale $F_{2}$ folds. These faults cut foliation at moderate to shallow angles (Figure 19). The other set has apparent normal displacement based on drag of compositional layers (Figure 20). Separation along faults of both sets is $<20 \mathrm{~cm}$. It is unclear whether the faults record two different periods of regional deformation, or if they are coeval and record localized deformation due to mapscale folding. Both sets of faults appear to be coeval with melt generation, as some leucocratic melt intrudes along faults, whereas other leucocratic melt is offset (Figure 17).

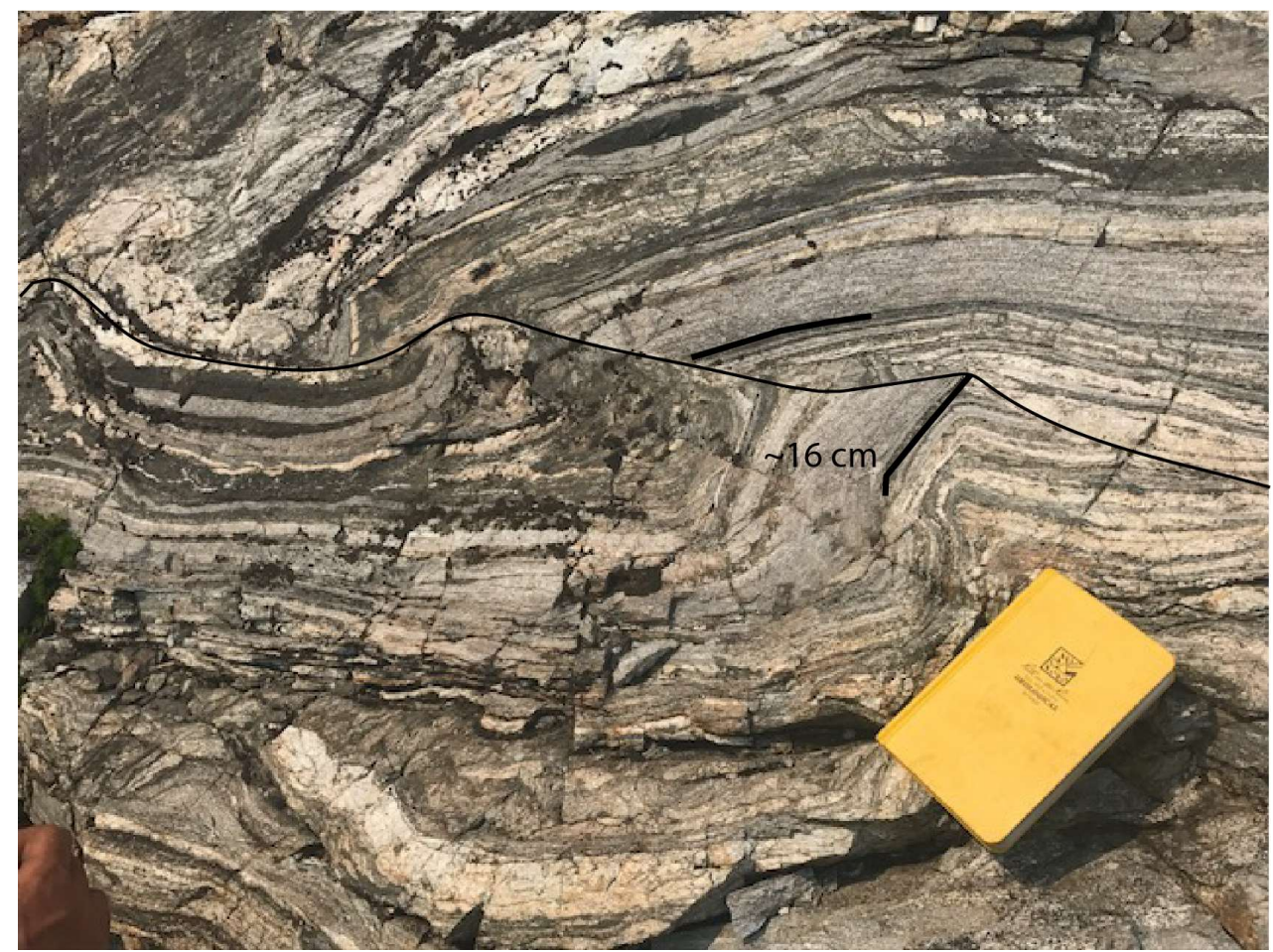

Figure 19. Outcrop-scale fold in the Spider Glacier area. The outcrop contains layers of micaceous quartzite (grey), hornblende gneiss (black) and leucotonalite (white). The fault has roughly $16 \mathrm{~cm}$ of separation based on the interpretation that layers denoted with black lines are equivalent. The field notebook is $16 \mathrm{~cm}$. 


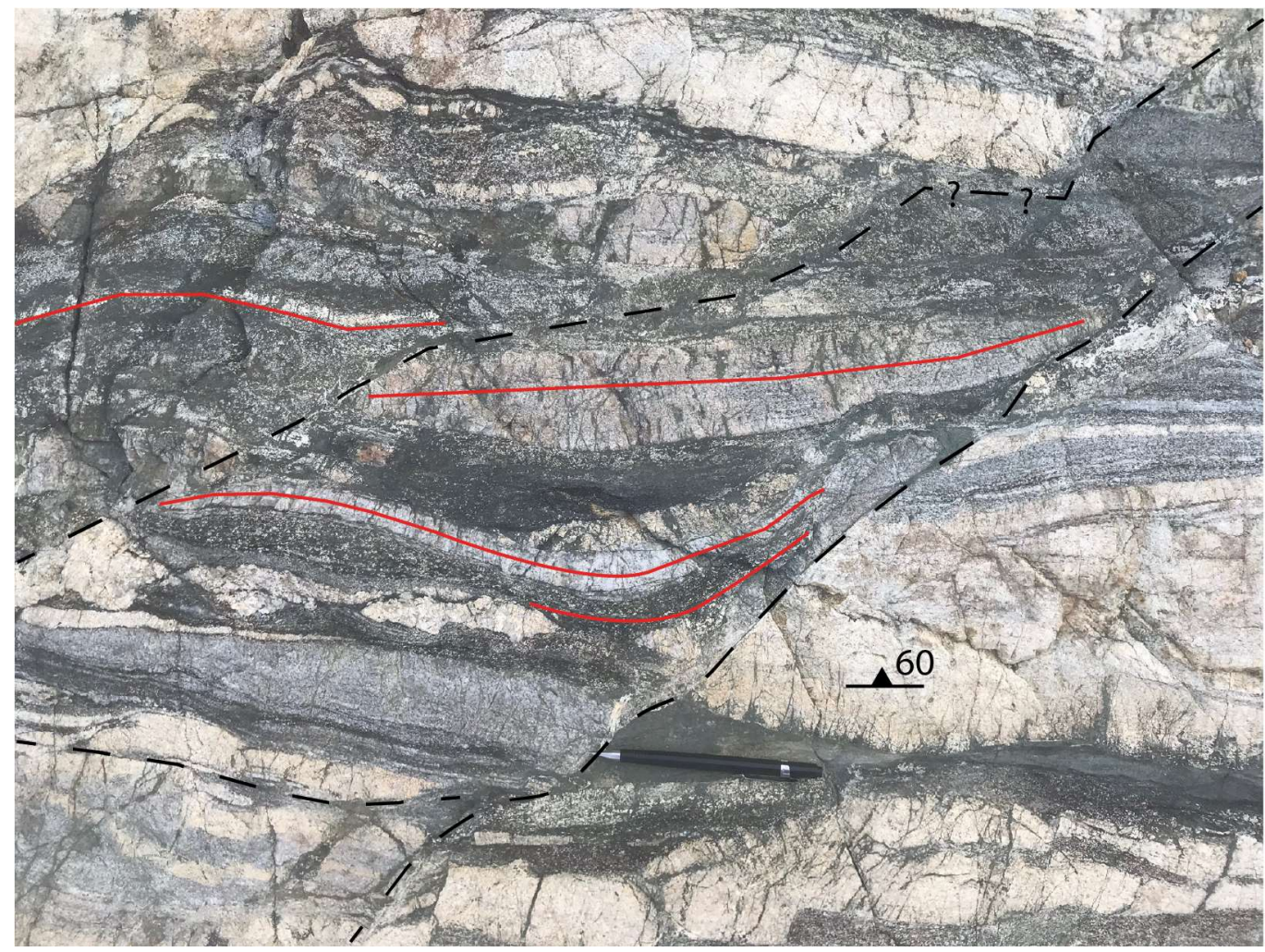

Figure 20. Zone of top-to-the-south, sinistral-normal shear. Dashed lines denote slip surfaces, question marks indicate where inferred. Red lines highlight layers within the shear zone and show normal drag. Attitude marker shows foliation dipping away at $60^{\circ}$. The foliation strikes $\sim 170^{\circ}$. The pencil is $13.5 \mathrm{~cm}$.

The Chiwawa discontinuity (new name) separates the Spider Glacier unit from the Swakane Gneiss and strikes south-southeast based on mapping by Cater and Crowder (1967). The discontinuity extends for $\sim 12 \mathrm{~km}$ from the Entiat fault in the south to the Cloudy Pass batholith in the north (Figure 3) (Cater and Crowder, 1967). South of the field area the discontinuity dips moderately to shallowly, based on map patterns by Cater and Crowder (1967). The only exposed portion of the discontinuity is immediately west of the northern end of Spider Glacier (Figure 21) and has an apparent shallow dip to the west. North of this exposure, however, Cater and Crowder (1967) show the trace of the discontinuity cutting topographic contours and thus is steeper and dips to the west. 


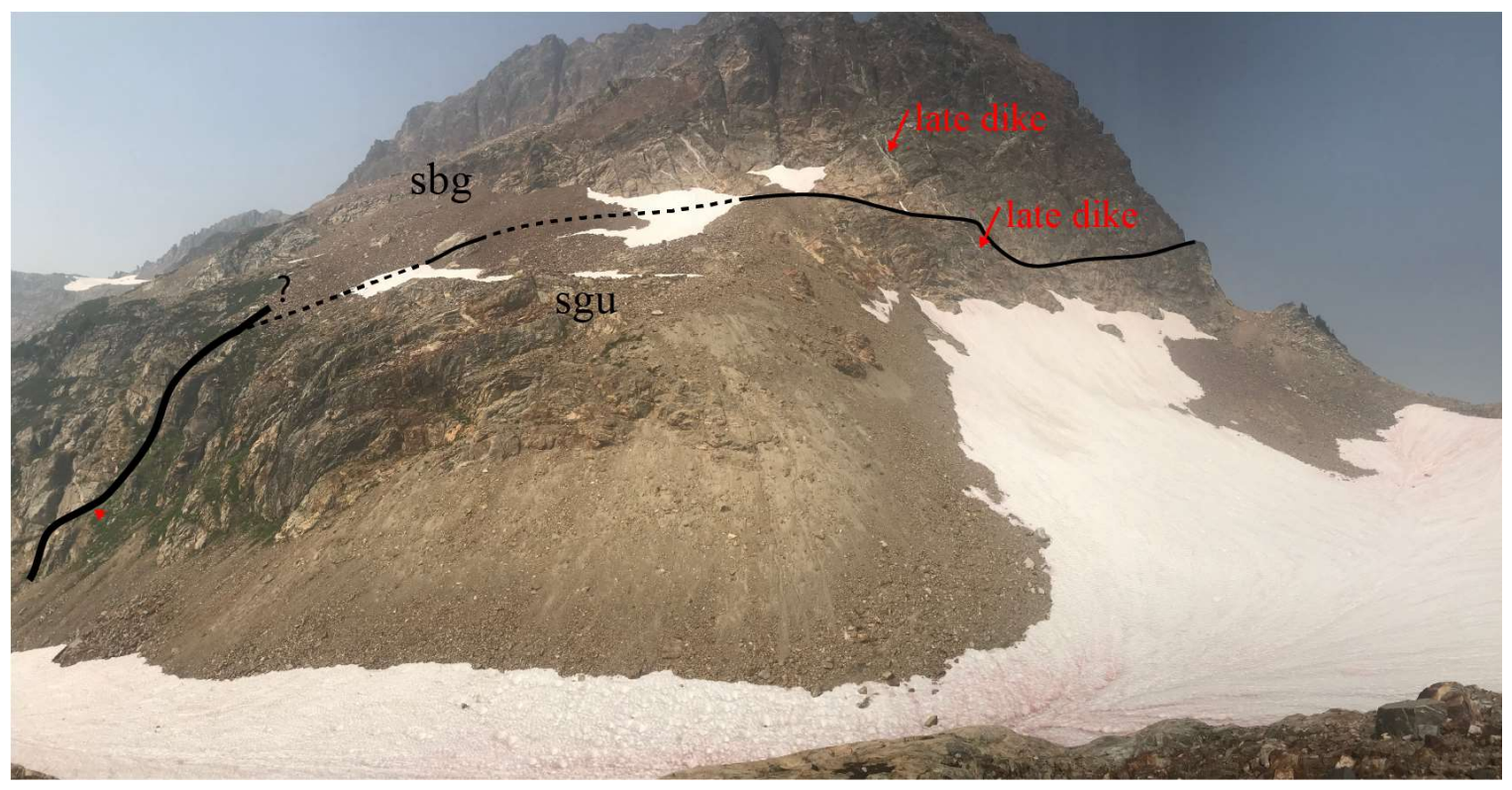

Figure 21. Photograph of the Chiwawa discontinuity. The view is looking north near the head of Spider Glacier. The peak in the middle of the photo is composed of Swakane Gneiss (sbg). The Chiwawa discontinuity, shown as a thin black line (partially dotted), separates the Swakane Gneiss (sbg) from the Spider Glacier unit (sgu). Late undated felsic dikes (red arrows and labels) crosscut the contact. A fault (bold black line) truncates the Chiwawa discontinuity.

Total displacement across the discontinuity is unknown and is large enough to juxtapose quartzo-feldspathic gneisses against hornblende-rich gneisses, and extensively folded rocks against only locally folded rocks. Motion on the discontinuity is only bracketed between $81 \mathrm{Ma}$, the youngest MDA of the Swakane Gneiss, and $22 \mathrm{Ma}$, the age of the Cloudy Pass batholith, which truncates the discontinuity. Ages of southweststriking, steeply northwest-dipping leucocratic sheets that cross the discontinuity would constrain latest fault movement (Figure 21). These sheets may be associated with the Cloudy Pass batholith, which underlies the area according to Cater and Crowder (1967).

In the Spider Glacier area, the Entiat fault strikes northwest (Cater and Crowder, 1967) and is marked by a 2-m-wide zone of fine-grained cataclasite at one location, and 
hornfelsed fault breccia at another. The Entiat fault is truncated to the north by the $\sim 22$ Ma Cloudy Pass batholith (Cater and Crowder, 1967). The straightness of the fault trace (Cater and Crowder, 1967) suggests that it is nearly vertical. Dextral offset of 30-40 km has been postulated by Tabor et al. (1989), whereas Brown et al. (1994) proposed only 4 $\mathrm{km}$ of dextral slip.

To further understand deformation in the Spider Glacier unit and Swakane Gneiss, quartz grain orientations in three samples from the Spider Glacier area were quantified. Experimental studies of quartz in natural rocks (e.g., Lister, 1977; Law et al., 1990) reveal that the lattice preferred orientations (LPOs) of quartz c- and a-axes, when plotted on stereonets, define points and/or girdles which correlate with movement along specific crystallographic planes, deformation rate, temperature, and the shape of the finite strain ellipsoid (e.g., Lister, 1977; see review in Passchier and Trouw, 2008) (Figure 22). Quartz LPOs can be measured using the electron backscatter diffraction (EBSD) technique in a scanning electron microscope (SEM).

Quartz LPOs were analyzed in three samples from the Spider Glacier area to compare microstructures in the Swakane Gneiss and Spider Glacier unit, and to test if deformation changes with proximity to the Chiwawa discontinuity. Samples from the Spider Glacier unit were collected $\sim 100 \mathrm{~m}$ and $<10 \mathrm{~m}$ from the Chiwawa discontinuity. The sample of Swakane Gneiss was also collected $<10 \mathrm{~m}$ from the Chiwawa discontinuity. The three samples display different quartz LPO patterns. 

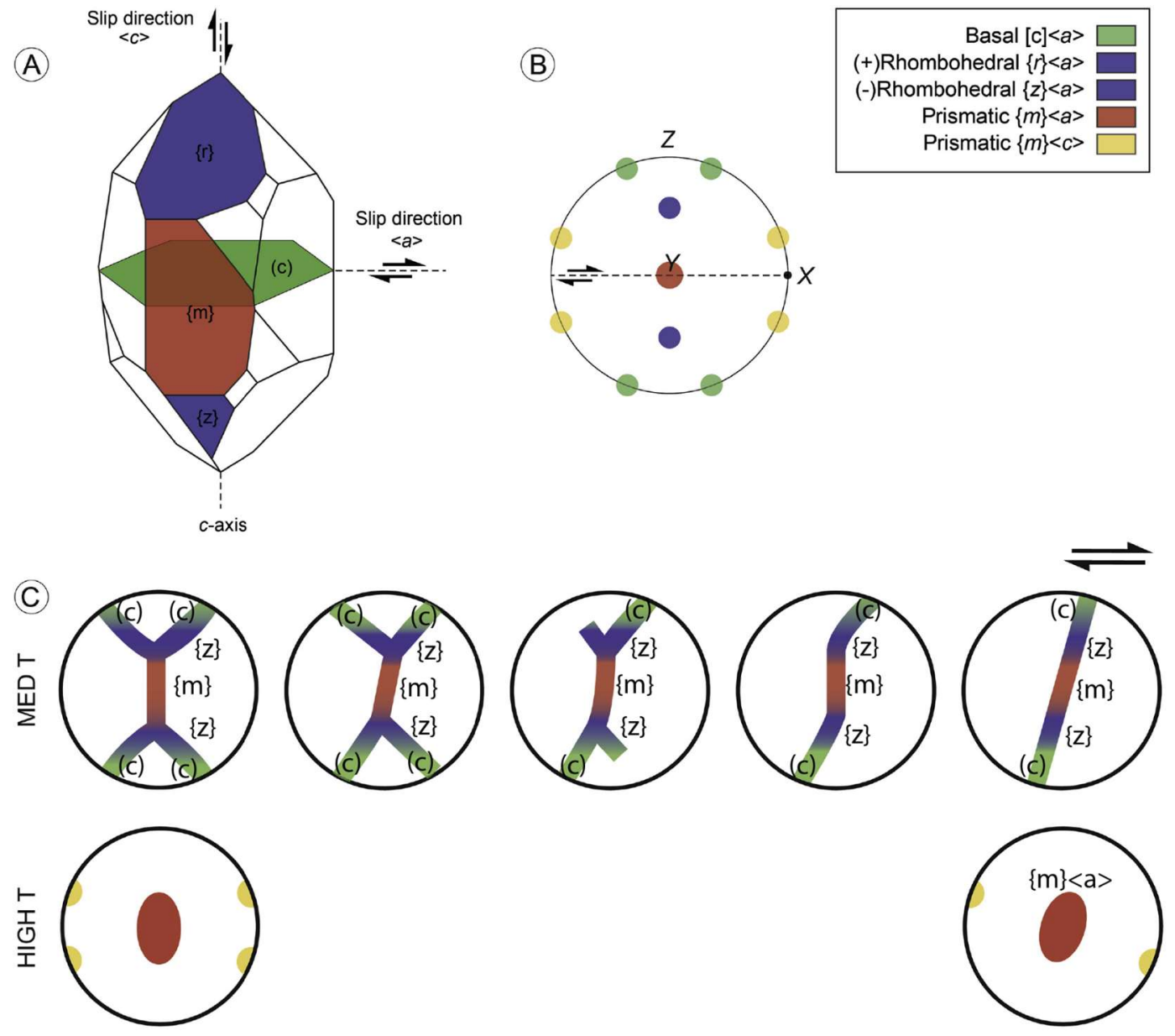

Increasing non-coaxial flow component

Figure 22. Schematic of expected c-axis orientations for quartz slip systems. Modified from Hunter et al. (2018). (A) Schematic diagram of a quartz crystal showing $\{\mathrm{r}\},\{\mathrm{m}\}$, (c), and $\{\mathrm{z}\}$ slip planes, $<\mathrm{a}>$ and $<\mathrm{c}>$ slip directions, and the c-axis. (B) Pole-figure showing expected quartz c-axis orientations for activation of different slip systems. (C) Diagram showing how a type-II cross girdle is affected by temperature and non-coaxial shear. 
The Spider Glacier unit sample collected $\sim 100$ m from the Chiwawa discontinuity (SG17-235.2) is micaceous quartzite. It was collected slightly east of the northern termination of Spider Glacier (Figure 6). Quartz LPOs in SG17-235.2 range widely, but define three maxima; one is nearly parallel to foliation and normal to lineation (Figure 23), and two are normal to foliation. Quartz a-axes orientations also vary widely, and do not have distinct maxima. The LPO pattern in SG17-235.2 is interpreted as a weak typeII crossed girdle with an additional maximum along the z-axis. This pattern differs from the sample collected closer to the Chiwawa discontinuity. Another sample from the Spider Glacier unit, SG17-114 was collected from hornblende-biotite gneiss $<10 \mathrm{~m}$ from the Chiwawa discontinuity (Figure 6) SG17-114 has quartz grain LPOs that trace a great circle from the upper left to lower right with a maximum in the upper left (Figure 23). This pattern is interpreted as an offset type-I crossed girdle. Quartz a-axes in SG17-114 cluster around two weakly defined maxima offset roughly $20^{\circ}$ from lineation (Figure 23). Directly across the discontinuity from SG17-114 (Figure 6), a sample of Swakane Gneiss (SG17-115) has quartz LPOs which cluster in the right hemisphere, and upper and lower left hemisphere and seem to define a girdle. SG17-114 also has an LPO maximum within the foliation plane, plunging roughly $30-45^{\circ}$ up-lineation. Quartz a-axes orientations are scattered, but most are in the left hemisphere.

In general, the patterns from the three samples tell different stories. The LPO pattern in the sample from Swakane Gneiss, SG17-115, records higher temperature deformation than the Spider Glacier unit samples, SG17-235.2 and SG17-114. In SG17-115, the LPO maximum in the right hemisphere is evidence for prismatic $\{\mathrm{m}\}<\mathrm{a}>$ slip in quartz grains, 


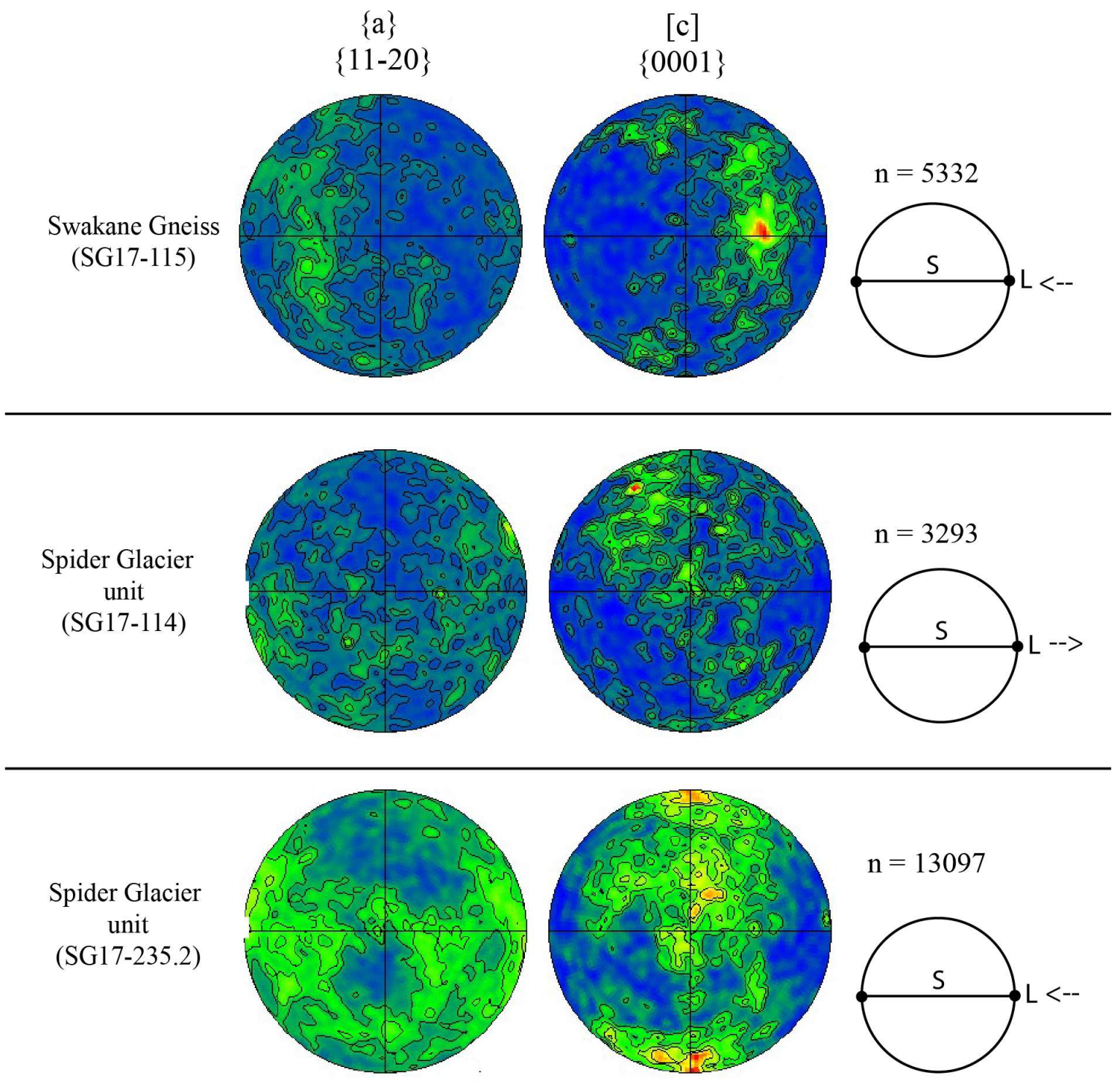

Figure 23. Plots of quartz c-axis orientations from three samples. Plots are lowerhemisphere equal-area stereonets. The circles on the right show the relative orientation of lineation (L) and foliation (S). Plots have $5^{\circ}$ half widths, and $5^{\circ}$ cluster sizes. Kamb contours range from $\sim 0.5$ to 1 . 
which occurs at high-temperatures (see review in Passchier and Trouw, 2008). The Spider Glacier unit sample collected farther from the Chiwawa discontinuity, SG17235.2, has the same high temperature indicator (shown by the LPO maximum roughly perpendicular to lineation) and has a type-II crossed girdle indicative of mediumtemperature coaxial strain (Figure 23). The Spider Glacier unit sample collected closer to the Chiwawa discontinuity has quartz LPOs which trace an offset type-I crossed girdle Type-I cross girdles record non-coaxial shear and in the case of SG17-114 the offset indicates top-up-lineation shear (Figure 23). In thin section, evidence for this top-up lineation shear sense was not conclusive (Figure 24). 


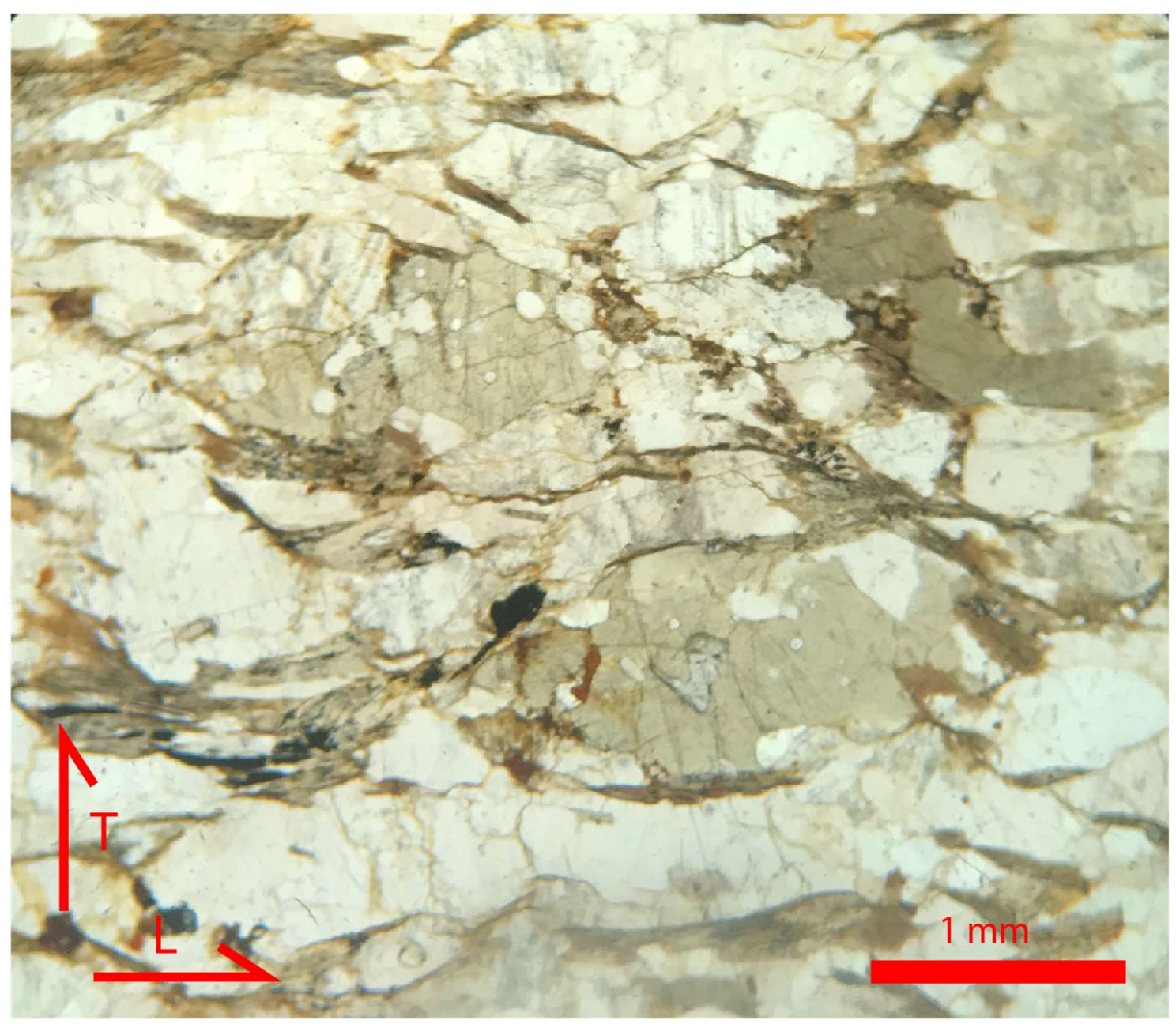

Figure 24. Photomicrograph of SG17-114. Red arrows labelled "T" and "L" denote direction toward top of thin section, and plunge of lineation, respectively. Note, biotite tends to wrap around plagioclase and hornblende grains without showing a clear asymmetry. 


\section{Holden Village Area}

In the Holden Village study area, a northwest-trending belt of Holden assemblage is intruded by the 78-72 Ma Cardinal Peak pluton to the east and is in contact with the Dumbell Orthogneiss to the west (Figure 4) (Cater and Crowder, 1967; Cater and Wright, 1967). All the Holden assemblage rocks, except for marble and actinolite schist, display a strong foliation defined by aligned minerals and compositional layering. Aligned minerals include quartz, plagioclase, biotite, muscovite, and hornblende. Compositional layers vary in relative abundances of mafic and felsic minerals. Foliation measurements from this study agree with more detailed structural mapping of the area by Hurban (1991). Foliation generally strikes southeast with an average orientation of $160^{\circ} / 69^{\circ}$ southwest, but foliation strike changes from east to west from $\sim 175^{\circ}$, near the contact with the Cardinal Peak pluton, to $\sim 105^{\circ}$ near the western edge of the map area (Figures 4 and 25). Foliations dip steeply southwest near the contacts with the Dumbell Orthogneiss and Cardinal Peak pluton, and more shallowly away from the contacts. The few lineations measured are shallow and plunge roughly north and south, and presumably correspond to the late north-northwest-trending, subhorizontal stretching lineation measured by Hurban (1991). He also measured early, locally preserved, steep stretching lineations (Hurban, 1991).

Foliation in the Holden Village area is folded into 10- to 100s-of-m wavelength folds. The orientations of fold axes were determined by inputting two to four fold limb attitudes into Allmendinger's Stereonet 10. The calculated axes plunge $3^{\circ}-6^{\circ}$ to the northwest $\left(320^{\circ}\right)$ and southeast $\left(140^{\circ}\right)$. These folds agree with the orientations of regional folding 
in the North Cascades (Tabor et al., 1989; Miller et al., 2006), but were not recognized by Hurban (1991) in the Holden Village area.

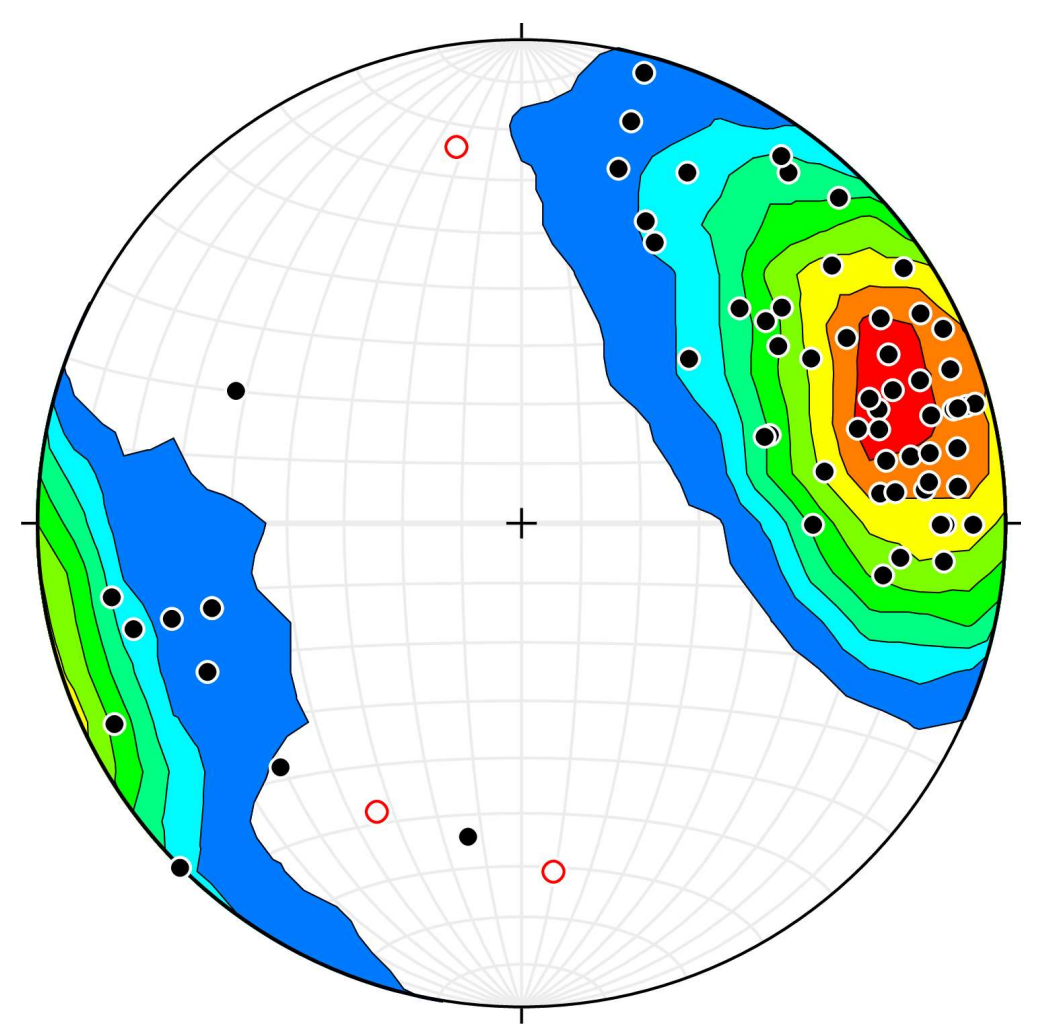

Figure 25. Poles to foliation and lineations in the Holden Village area. Lowerhemisphere equal area stereographic projection. Poles to foliation $(n=67)$ are shown with black dots and have a maximum at $160^{\circ} / 69^{\circ}$. Lineations $(\mathrm{n}=3)$ are shown with red circles. Kamb contours calculated on Allmendinger Stereonet 10: spacing interval, 2; significance level, 3; number of grid nodes, 20. 
Microstructures were analyzed in fourteen samples in the Holden Village area with the goal of comparing them with microstructures in the Spider Glacier area. In the Holden Village area, five of nine samples have interlobate grains, island grains [dissection structure of Urai et al., (1987)], and reticular grain boundaries, all textures indicative of grain boundary migration recrystallization. Four of the samples also have a fine-grained mantle texture or slightly bulged grain margins, indicative of relatively lowtemperature grain boundary bulging recrystallization (e.g., Passchier and Trouw, 2008). Two samples lack deformation microstructures and have variably oriented, undeformed biotite grains suggesting extensive annealing. The microstructures from the Holden assemblage are interpreted to indicate that the rocks experienced medium to high temperature recrystallization followed by low temperature deformation. Some rocks were extensively annealed. The medium- to high-temperature recrystallization is likely coeval with foliation formation, whereas lower-temperature deformation was likely more localized. This interpretation agrees with observations by Hurban (1991), who noted localized greenschist-facies deformation.

\section{Carne Mountain Area}

In the Carne Mountain area, rocks mapped as Holden assemblage by Cater and Crowder (1967) occur on both sides of the Entiat fault. I interpret the rocks west of the fault as part of the Spider Glacier unit. The fault strikes southeast $\left(\sim 150^{\circ}\right)$ and dips steeply, based on map patterns (Cater and Crowder, 1967).

Foliation in the Spider Glacier unit is defined by compositional layers, elongate quartz grains, and aligned biotite grains. The foliation was only measured at two 
locations, where it strikes $343^{\circ}$ and $012^{\circ}$ and dips $62^{\circ}$ and $85^{\circ}$ eastward, respectively. No outcrop-scale folds were observed.

In the Holden assemblage, foliation is similarly defined by compositional layering, elongate quartz grains, and aligned biotite grains. Folds of foliation in the Holden assemblage range from $10-\mathrm{cm}$ to $100 \mathrm{~s}-\mathrm{of}-\mathrm{m}$ in wavelength and have a variety of styles. At the outcrop-scale, foliation is folded into tight to open, asymmetric disharmonic folds. Layer thickness is not consistent in most folds. Some ptygmatic folds of felsic sheets are refolded into open, asymmetric folds, and other $\sim 10 \mathrm{~s}-\mathrm{of}-\mathrm{cm}$-scale folds have $\mathrm{cm}$-scale crinkle folds in the hinge. Outcrop-scale fold hinge lines are variably oriented, and they commonly plunge moderately north, but also west and southwest, and one hinge line plunges east. The average orientation of the outcrop-scale hinge lines $(n=21)$ is $60^{\circ} / 314^{\circ}$, but only three hinge line orientations fall within error of the mean, and this variability in orientations implies that there are multiple fold generations and/or that some folds were re-oriented by the Entiat fault. All foliations $(\mathrm{n}=15)$ in the area define a girdle implying map-scale folding with an axis oriented $41^{\circ} / 314^{\circ}$ (Figure 26). Map-scale folds have wavelengths of $\sim 100 \mathrm{~m}$ based on map patterns. 


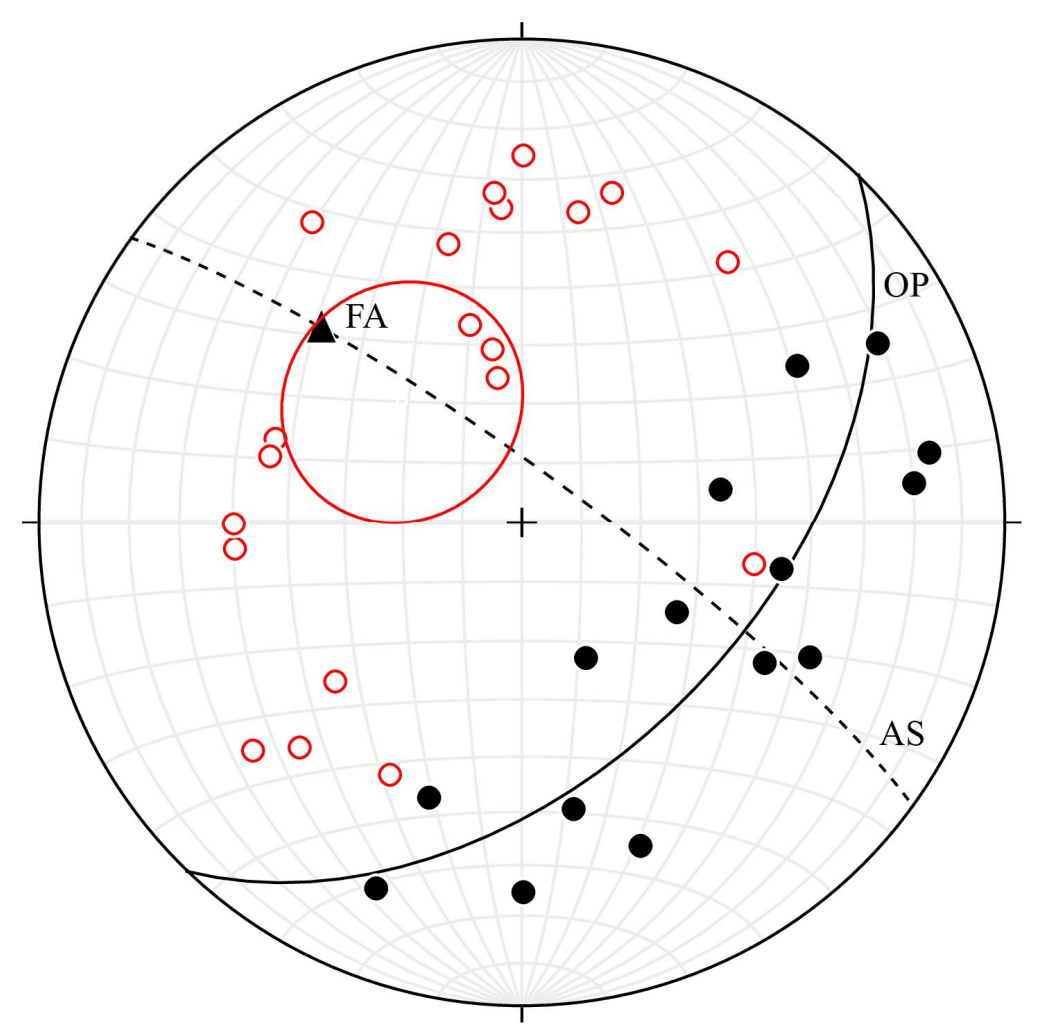

Figure 26. Poles to foliation and fold axes in the Carne Mountain area. Lowerhemisphere equal area stereographic projection. Foliations $(n=15)$ are shown with black dots, and define a fold with an orthogonal plane (OP) oriented $044^{\circ} / 49^{\circ}$ (solid black line), a fold axis (FA) oriented $42^{\circ} / 342^{\circ}$ (black triangle), and an axial surface (AS) oriented $308^{\circ} / 81^{\circ} \mathrm{NE}$ (dotted line). Fold hinge lines $(\mathrm{n}=21)$ are shown with red circles. The mean vector of fold axes is oriented $60^{\circ} / 314^{\circ}$, with statistical error shown as a large red circle.

\section{Rock Creek Area}

In the Rock Creek area, I mapped a 100-m-wide belt of the Holden assemblage along a ridge east of the Entiat fault, and other portions of the Holden assemblage on the eastern slopes of Rock Creek where it is in contact with the Eocene Rampart Mountain pluton (Figure 5). The Entiat fault bounds the Holden assemblage on the west and map patterns (Cater and Crowder, 1967) suggest a subvertical orientation for the fault. 
Foliation in the Holden assemblage is defined by aligned quartz, plagioclase, biotite, muscovite and hornblende, and compositional layers with varying amounts of mafic and felsic minerals. Foliation is folded into a synform plunging $17^{\circ}$ to the northwest $\left(342^{\circ}\right)$ (Figures 5 and 27), which is intruded at its core by Seven-Fingered Jack granitoid (Paterson and Miller, 1998). My map does not illustrate the fold well, but the fold was mapped by Cater and Crowder (1967) and Paterson and Miller (1998). The calculated axial surface of the fold strikes south-southeast $\left(174^{\circ}\right)$ and dips $57^{\circ}$ west (Figure 27). Local lineations $(\mathrm{n}=4)$ are defined by hornblende and/or mica. The four measured lineations plunge gently to the northwest and southeast, and moderately to the northeast and northwest.

Microstructures in the Rock Creek area were examined in only one sample from the east side of Rock Creek. The sample is hornblende gneiss in which hornblende occurs in fine- to medium-grained, foliation-parallel aggregates. Quartz grain boundaries are commonly interlobate, with island grains, reticular grain angles and pinning structures. Quartz, hornblende and plagioclase grains display weak undulatory extinction. Quartz grains display deformation banding. At least three microfaults with $<1 \mathrm{~mm}$ of separation cut across mineral grains. Quartz grain size is reduced to $<0.01 \mathrm{~mm}$ along the microfaults. The textures indicate grain size reduction in hornblende and grain boundary migration recrystallization in quartz. 


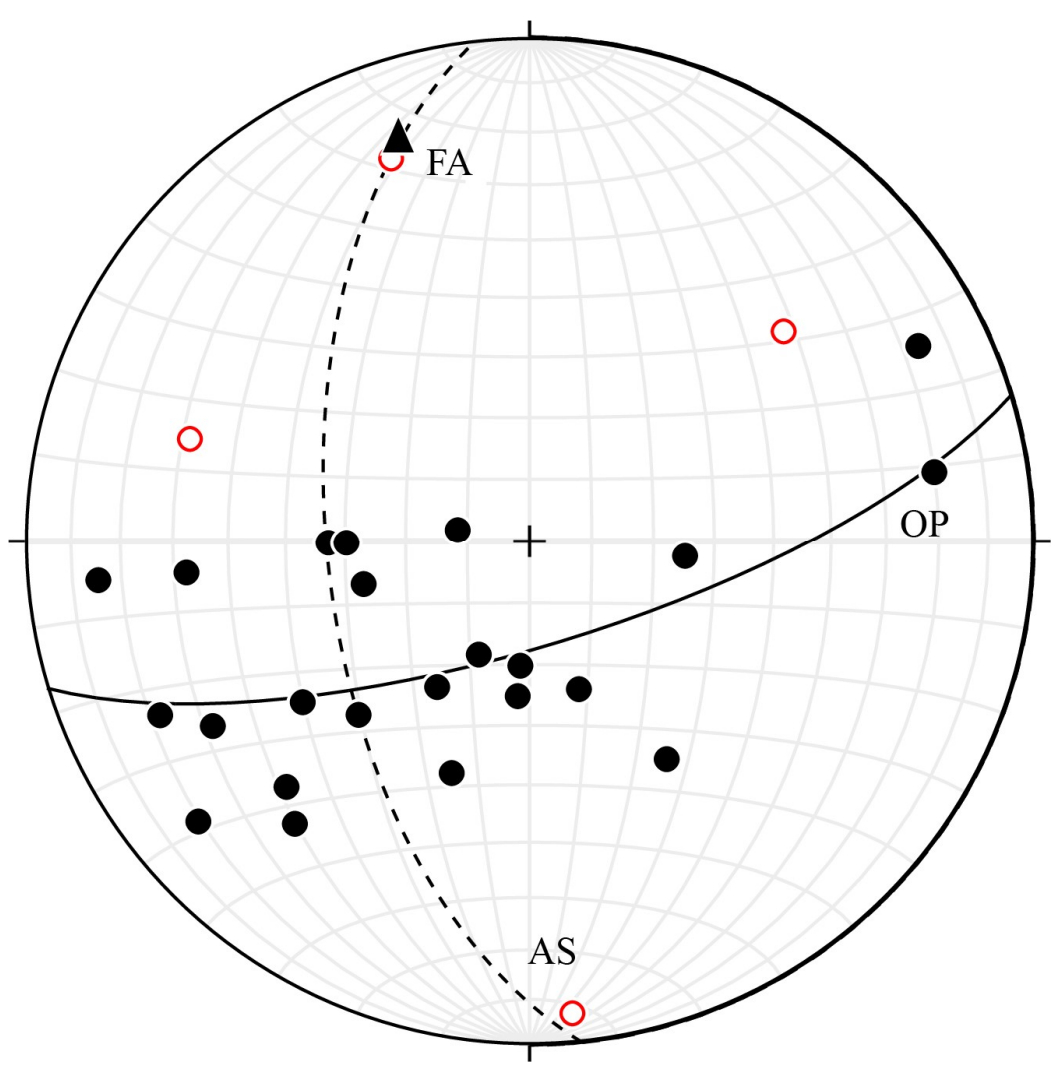

Figure 27. Poles to foliation and lineations in the Rock Creek area. Lower-hemisphere equal area stereographic projection. Poles to foliation $(\mathrm{n}=22)$ are shown as black dots, which define a fold with an orthogonal plane oriented $073^{\circ} / 73^{\circ}$ (solid black line labelled "OP”), an axis oriented 17\%/342 (black triangle labelled "FA"), and an axial surface oriented $174^{\circ} / 57^{\circ}$ (dashed line labelled “AS").

\section{GEOCHRONOLOGY}

The goal of the geochronologic research in this study is to constrain the ages of the Holden assemblage and the Spider Glacier unit. Zircon was separated from two samples of Holden assemblage collected $\sim 5 \mathrm{~km}$ across strike from one another in the Holden Village area (Figure 4), and from one sample of Spider Glacier unit collected near the Chiwawa discontinuity (Figure 6).

The western Holden assemblage sample (SG17-068.2) is a medium- to fine-grained 
leucogneiss interlayered on a meter-scale with calc-silicate gneiss and amphibolite. The leucogneiss is interpreted as a sheet of igneous material which intruded the layers prior to metamorphism. This interpretation is founded on cross-cutting relationships observed in the field, and petrologic characteristics observed in thin section. The leucogneiss layer is more homogeneous than, and truncates adjacent amphibolite and hornblende gneiss layers, suggesting the leucogneiss is an orthogneiss. Furthermore, the leucogneiss has a greater amount of plagioclase ( $\sim 45 \%)$ than would be expected in typical sedimentary material, and includes several plagioclase grains with oscillatory zoning, which is indicative of igneous growth. These observations support the classification of SG17068.2 as an orthogneiss sample.

Zircons from SG17-068.2 are generally $\sim 100 \mu \mathrm{m}$ long, and range from $\sim 50-150 \mu \mathrm{m}$ (Figure 28). Aspect ratios range from $\sim 1: 1$ to $4: 1$ and are mostly $\sim 2: 1$. Euhedral grains are rare. Most grains have growth and/or sector zoning, and all the grains are partially resorbed and/or contain pockets of melt. Fractures pervade most grains and tend to occur along the margins and parallel to growth zoning. Some grains have $<10 \mu \mathrm{m}$ in diameter xenocrystic cores. Metamorphic rims are absent or are very thin $(<5 \mu \mathrm{m})$. Zircons from SG17-068.2 tend to form a coherent grouping of limited age range (280-250 Ma), which further supports that the sample is igneous in origin. 


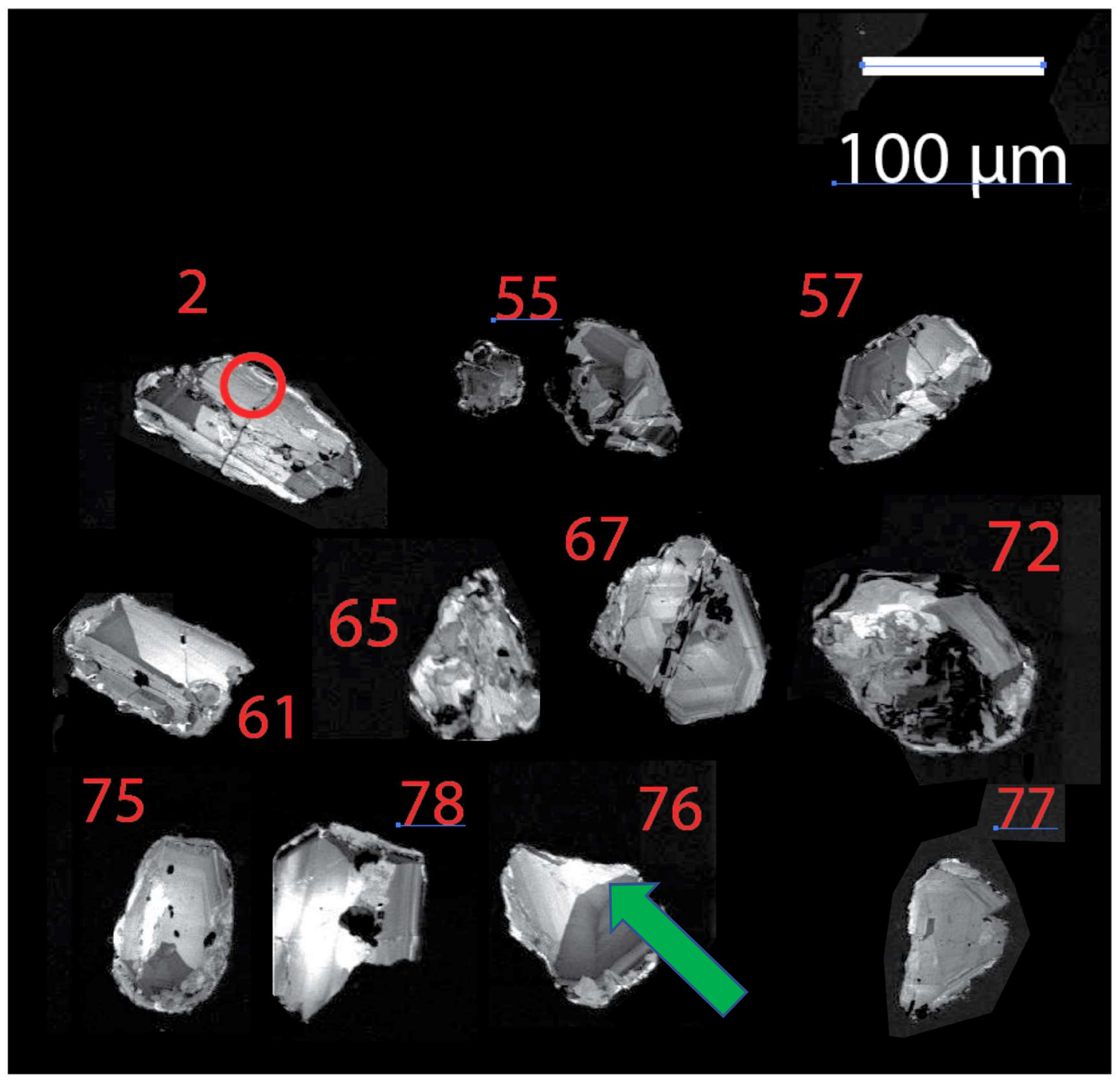

Figure 28. Cathodoluminescence (CL) imagery of zircons from SG17-068.2. CL-dark pockets occur in many grains. Most of the grains are sector zoned and the edges of the grains appear serrated. A boundary between zoned sectors in grain \#76 is denoted with a green arrow. Metamorphic rims are either absent or very thin $(<5 \mu \mathrm{m})$. Red circle on grain \#2 shows relative laser diameter. 
$\mathrm{Th} / \mathrm{U}$ ratios distinguish two groups of zircons in SG17-068.2; one group with lower $\mathrm{Th} / \mathrm{U}$ ratios and a broad age range from $\sim 110-290 \mathrm{Ma}$, and another with higher $\mathrm{Th} / \mathrm{U}$ ratios and a narrower age range from $\sim 250-290 \mathrm{Ma}$ (Figure 29). The group with lower $\mathrm{Th} / \mathrm{U}$ ratios is interpreted to have been affected by metamorphism because low thorium abundance in zircon suggests coeval growth of monazite, which grows during metamorphism. Zircon grains in the "low $\mathrm{Th} / \mathrm{U}$ ratio" group tend to have $\mathrm{Th} / \mathrm{U}<0.9$, and therefore $\mathrm{Th} / \mathrm{U}=0.9$ is the threshold value used to separate metamorphic and nonmetamorphic grains (Figure 29). The metamorphic grains did not display distinct morphologies in cathodoluminescence imagery. The grains with $\mathrm{Th} / \mathrm{U}>0.9$ were used to calculate a mean weighted age, interpreted as a crystallization age. These grains $(n=26)$ yield a crystallization age of $267.0 \pm 5 \mathrm{Ma}$ (mean standard weighted deviation [MSWD] $=2.2$ ) (Figures 30-31). The age was calculated using ISOPLOT v4.10. Concordia plots were generated with $E D \_R E D U X$.

Alternatively, the leucogneiss from which SG-17-068.2 was sampled could be interpreted as meta-sedimentary. The meter-scale layering of leucogneiss, amphibolite and hornblende gneiss agrees with a sedimentary protolith. If the leucogneiss is metasedimentary, then zircons in SG17-068.2 would yield a MDA of 133.6 $\pm 12 \mathrm{Ma}$ (Figure 32), calculated by averaging the ages of the youngest three grains with overlapping error. This alternative cannot be ruled out but is not favored because the leucogneiss truncates adjacent layers, has high concentrations of plagioclase, includes plagioclase with oscillatory zoning, and has zircons with a relatively narrow range of ages on a concordia diagram (Figure 30). 


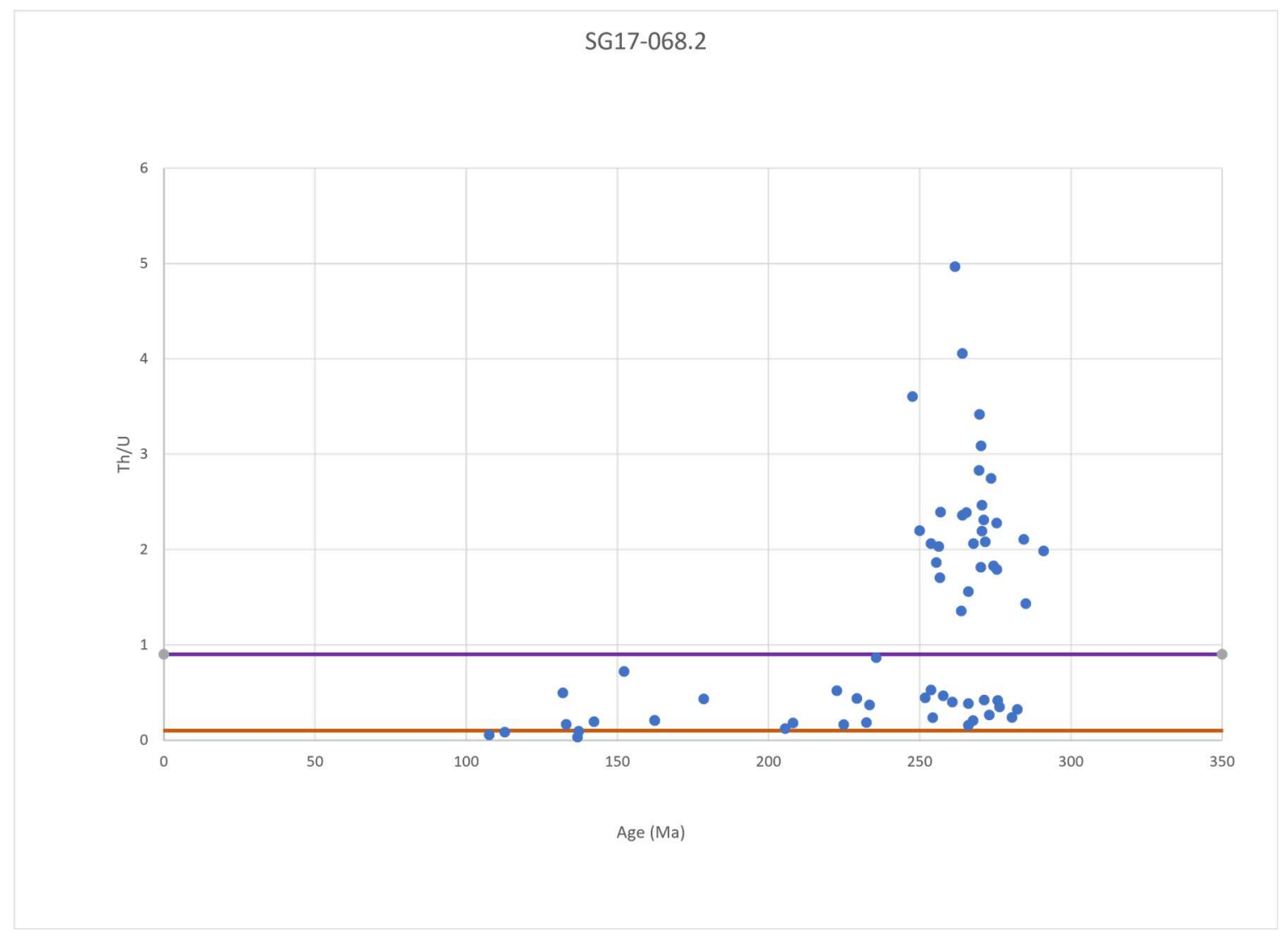

Figure 29. Scatter plot showing Th/U by age fors zircons in SG17-068.2. Each zircon grain is shown as a blue dot. Previous studies used a Th/U ratio of 0.1 (orange line) as the cut off below which grains are considered affected by metamorphism. This study used a higher value of $\mathrm{Th} / \mathrm{U}=0.9$ (purple line), which better separates the data into distinct groupings. 


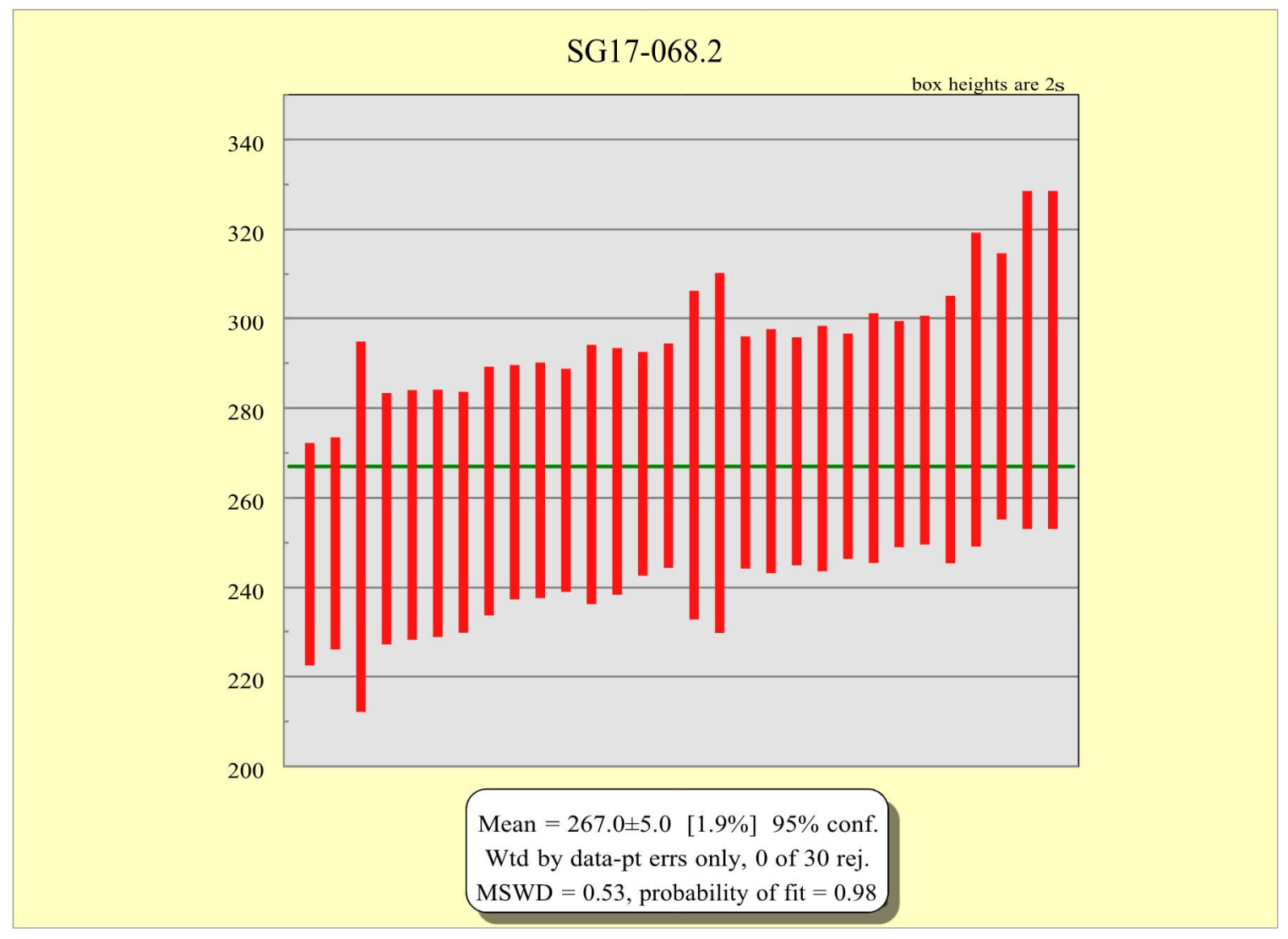

Figure 30. Age distribution of SG17-068.2 zircons with $\mathrm{Th} / \mathrm{U}>0.9(\mathrm{n}=26)$. Box heights are $2 \sigma$. The weighted mean age, shown with a green line, is $267.0 \pm 5 \mathrm{Ma}$. 


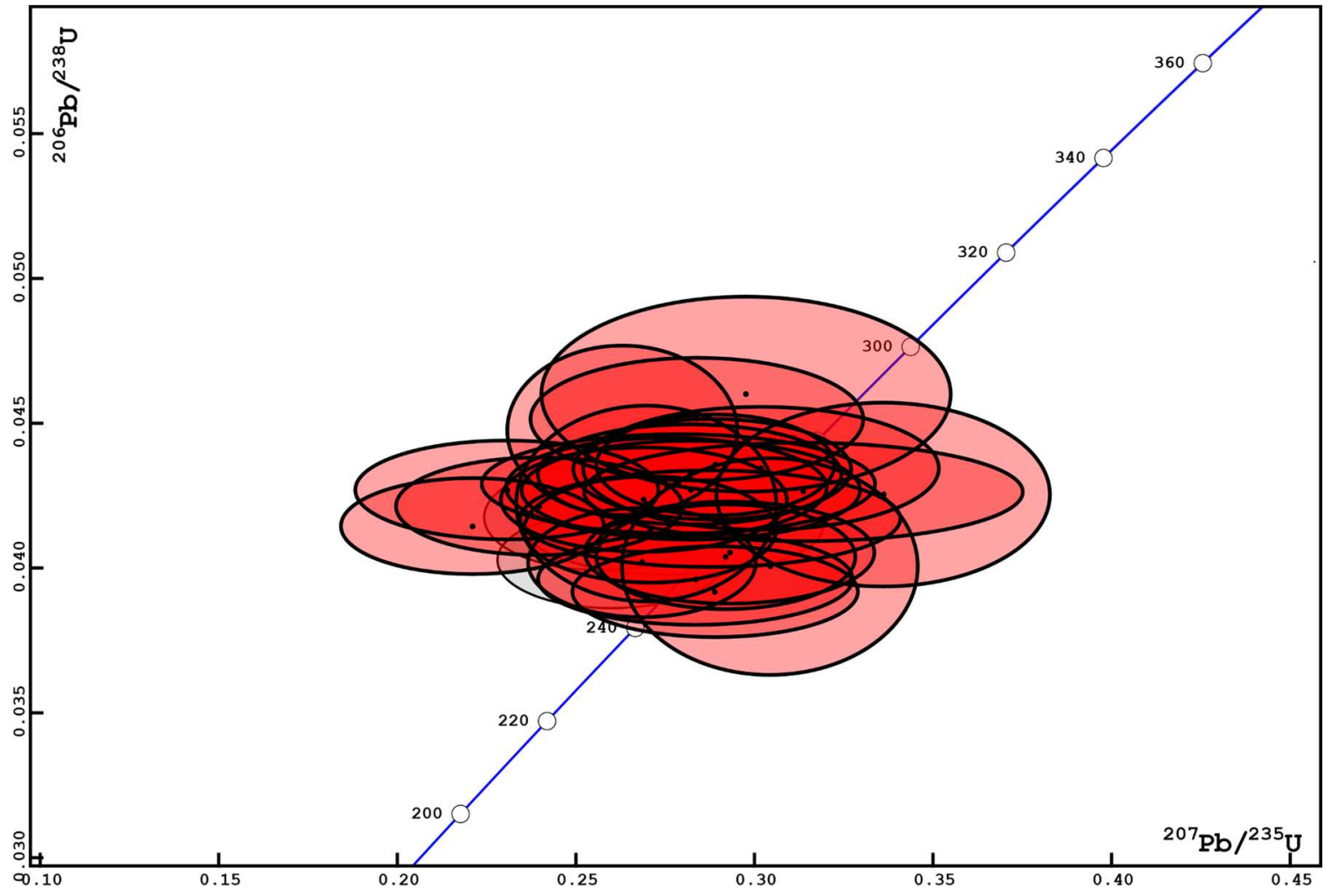

Figure 31. Concordia plot for zircons from SG17-068.2. 


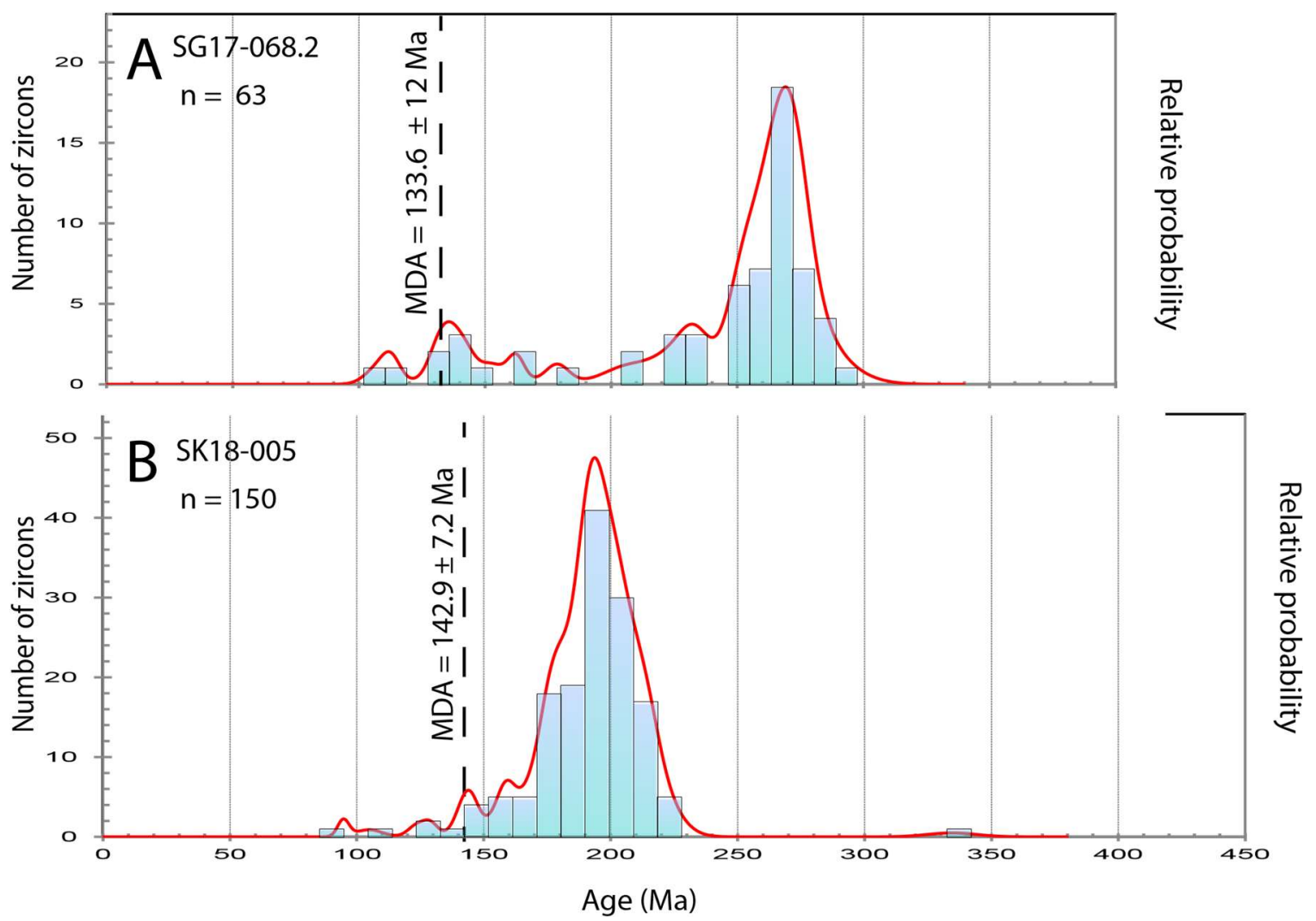

Figure 32. Probability density plots (PDPs) for SG17-068.2 and SK18-05. The MDAs apply if the samples are interpreted as meta-sedimentary rock samples. Histograms show number of zircons. (A) the MDA for SG17-068.2 is $133.6 \pm 12 \mathrm{Ma}$. The zircon ages form a prominent cluster at $270 \mathrm{Ma}$ and a scatter $\mathrm{f}$ younger grains with small peaks at $\sim 140$ and $\sim 230$ Ma. (B) the MDA for SK18-005 is 142.9 \pm 7.2 Ma. Most of the zircon ages are in a broad peak ranging from 170-230 Ma with its maximum at $\sim 195 \mathrm{Ma}$. Younger grains form small peaks at 140 and $160 \mathrm{Ma}$. The broad peak from 170-230 has an MSWD of 5.5 and a probability of fit (POF) of 0.0 , and therefore represents a composite of populations. SK18-05 was sampled roughly $5 \mathrm{~km}$ east of SG17-068.2 
Another sample (SK18-05) of Holden assemblage was collected $\sim 5 \mathrm{~km}$ across strike to the east of SG17-068.2 (Figure 4). SK18-05 is fine-grained biotite gneiss, interpreted as intermediate to siliceous meta-volcanic rock because the zircons tend to have growth zoning (Figure 33) and, like SG17-068.2, the zircon ages define a relatively narrow age range on a concordia diagram (Figure 34). The zircons $(n=148)$ in SK18-05 range from 50-250 $\mu \mathrm{m}$, and many grains are $<100 \mu \mathrm{m}$ long. Aspect ratios range from 1:1 to 3:1. The grains are mostly growth zoned, and less commonly show sector zoning (Figure 33). More than half of the grains have 5-10 $\mu \mathrm{m}$-thick, unzoned rims, which are interpreted as metamorphic.

Unlike SG17-068.2, Th/U ratios do not distinguish groups of grains (Figure 35). $\mathrm{Th} / \mathrm{U}$ ratios are generally greater than 0.1 , the commonly used threshold for distinguishing grains which grew coevally with monazite. The two dated rims, which are interpreted to have grown during metamorphism, have $\mathrm{Th} / \mathrm{U}$ ratios between $0.4-0.8$, suggesting that the $\mathrm{Th} / \mathrm{U}=0.1$ threshold is not appropriate for SK18-05. Therefore, it is difficult to justify removing younger grains from the weighted mean age calculation. 
The weighted mean age, interpreted as an approximate crystallization age, of SK1805 , is $187.8 \pm 36 \mathrm{Ma}($ Figure 36$)(\mathrm{n}=146 ; \mathrm{MSWD}=21)$. This age includes all the zircon ages with the exception of the rim ages. The high MSWD and the presence of outlier grains $(94.7 \pm 4.5 \mathrm{Ma}$, and $335 \pm 19 \mathrm{Ma})$ suggest that some of the grains are inherited and/or experienced significant lead-loss (Figure 36). By removing ages interpreted as being a result of lead-loss or inheritance, the data yield an alternative age of $193.3 \pm 7.3$ Ma $(\mathrm{MSWD}=1.5 ; \mathrm{POF}=0.003)$.

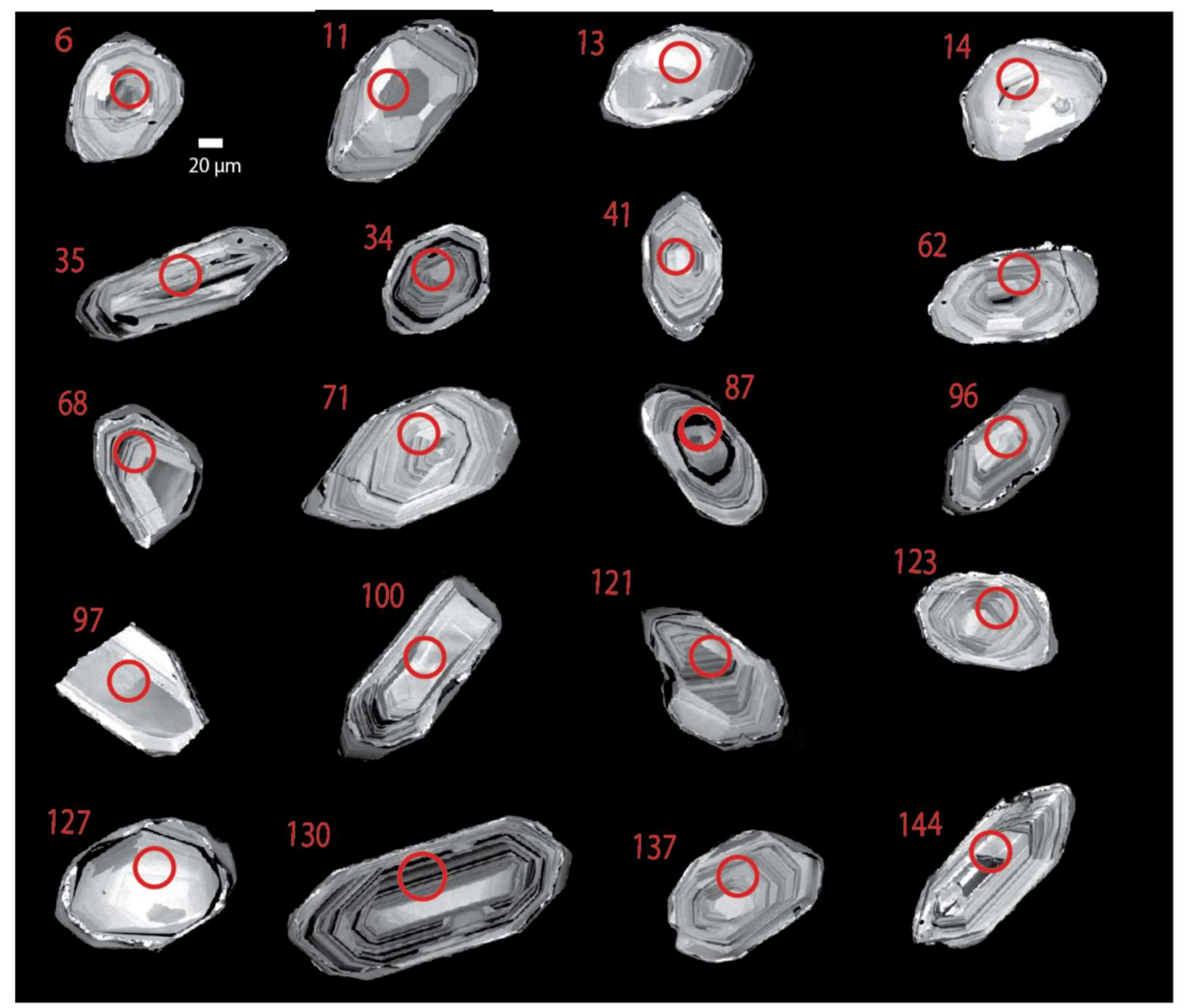

Figure 33. CL imagery of zircons from the Holden assemblage (SK18-05). The rock is fine-grained biotite gneiss. The zircons range from 50-250 $\mu \mathrm{m}$, but many are $<100 \mu \mathrm{m}$ long. Growth zoning is common. More than half of the grains have metamorphic rims. Red circles mark the locations of laser pits. 


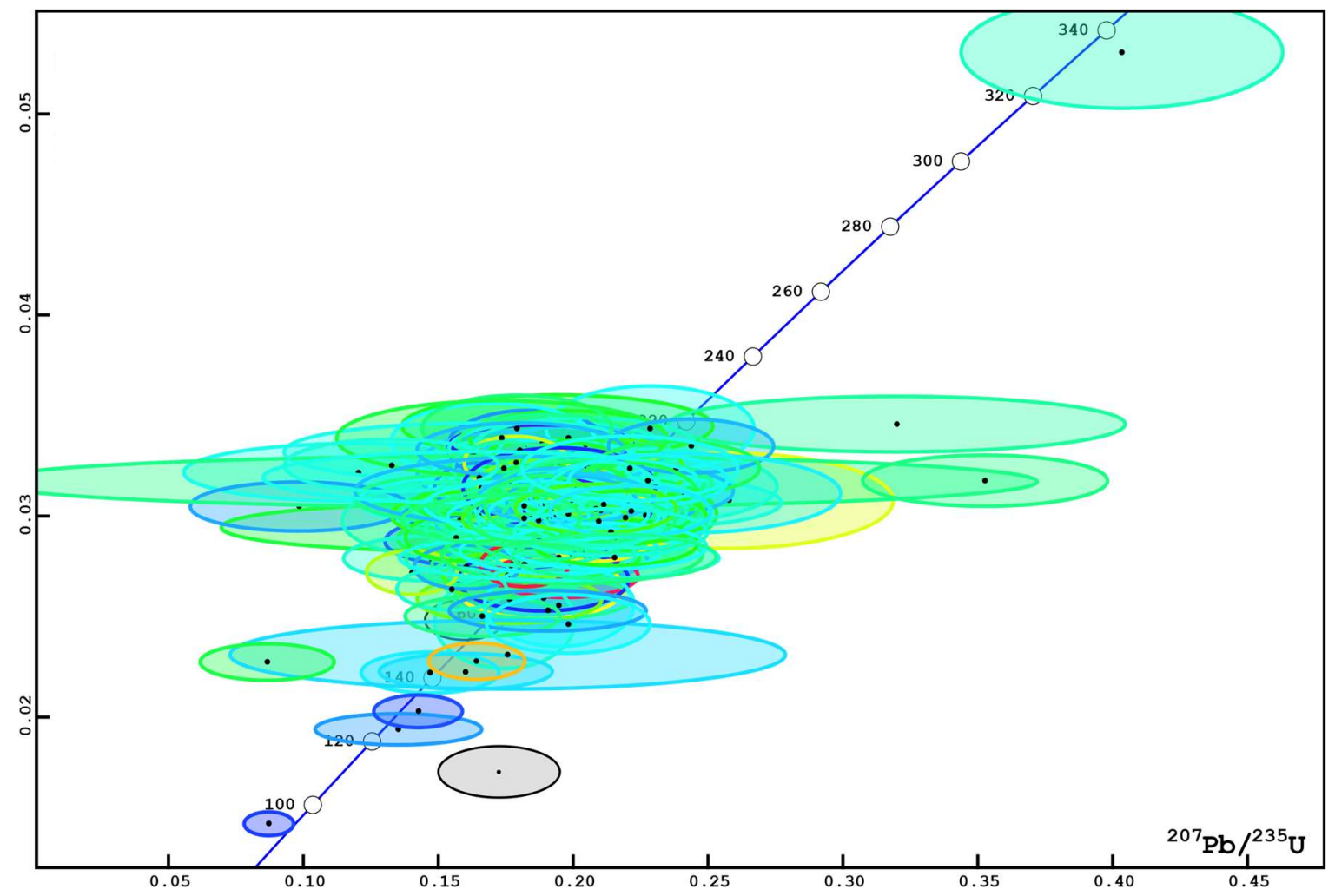

Figure 34. Concordia plot for zircons from SK18-05. One grey ellipses shows a rim analysis which was excluded from the age calculation, the other grey ellipse is obscured by data. The uppermost and lowermost ellipses are the two outliers $(94.7 \pm 4.5 \mathrm{Ma}$, and $335 \pm 19 \mathrm{Ma}$ ). $\mathrm{Th} / \mathrm{U}$ ratios are represented by ellipse color. The intensity of the blue shading correlates with decreasing $\mathrm{Th} / \mathrm{U}$ ratios. All $\mathrm{Th} / \mathrm{U}$ ratios are greater than 0.1 . 


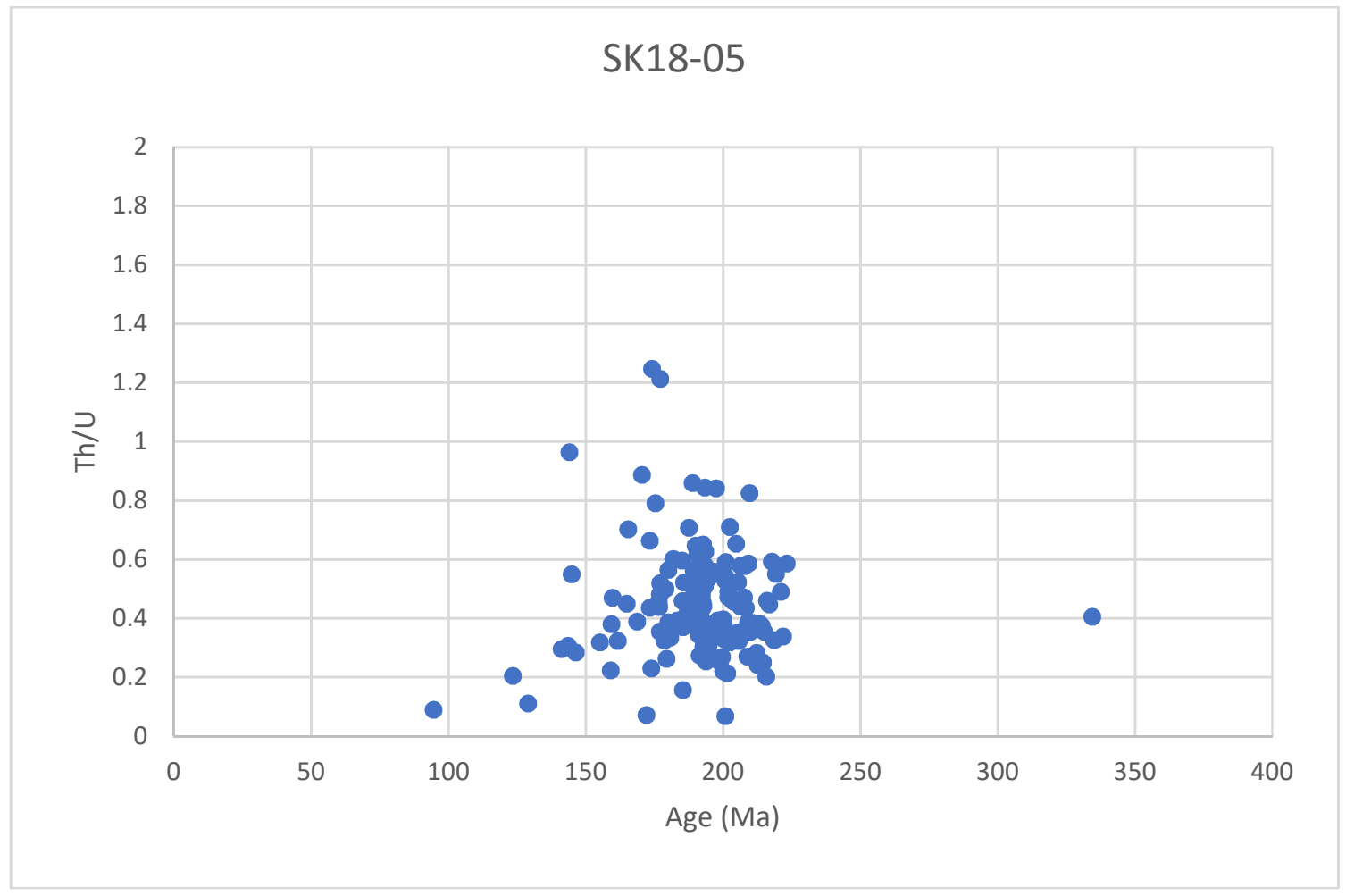

Figure 35. Scatter plot of Th/U by age for all zircon grains for SK18-05. Each grain is shown as a blue dot. 


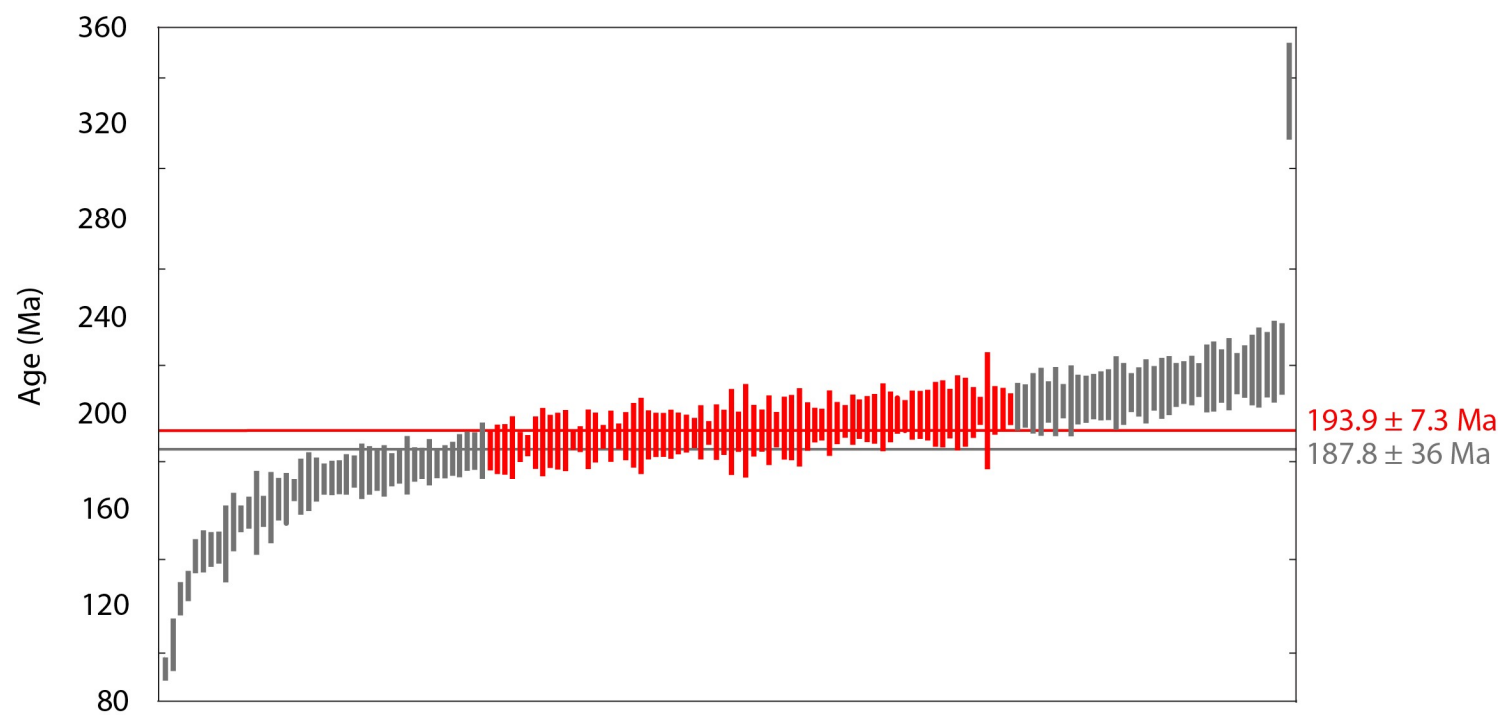

Figure 36. Weighted mean age distribution for zircons from SK18-05. Two metamorphic rim ages are excluded. Box heights are $2 \sigma$. The weighted mean age, shown with a grey line, is $187.8 \pm 36 \mathrm{Ma}(\mathrm{n}=146 ; \mathrm{MSWD}=21)$. By excluding grains interpreted as affected by lead-loss or inheritance (shown as grey bars), the data yield an alternative age, shown with a red line, of $193.9 \pm 7.3 \mathrm{Ma}(\mathrm{n}=71 ; \mathrm{MSWD}=1.5)$.

A sample of hornblende-biotite gneiss was collected from the Spider Glacier unit (SG18-025) near the Chiwawa discontinuity. The hornblende-biotite gneiss is interpreted as meta-sedimentary, as it is composed of interlayers of different rock types which likely formed a diverse package of sedimentary rocks prior to metamorphism. Unlike the zircons in SG17-068.2, the zircon age range in SG18-025 is broad and agrees with a sedimentary protolith.

Zircon $(\mathrm{n}=130)$ from SG18-025 is mostly $75-125 \mu \mathrm{m}$ and ranges from $50-150 \mu \mathrm{m}$ long, and from ellipsoidal to fragmental. Aspect ratios are generally 2:1 and range from 1:1 to 3:1. Eighty of 130 zircon grains contain xenocrystic cores and metamorphic rims. 
Primary growth zoning occurs in most cores. Moderate to strong resorption occurs either around or within the cores. Mosaic textures are common in relatively younger grains. Zircons that lack cores and rims have ages in a broad plateau between 160-85 Ma with peaks at $\sim 130, \sim 120$, and $\sim 90 \mathrm{Ma}$ (Figure 37 ). The plateau drops sharply at $160 \mathrm{Ma}$. Three Paleozoic grains occur between 400-290 Ma. Th/U ratios decrease gradually from $118 \mathrm{Ma}$ to $110 \mathrm{Ma}$, and at $110 \mathrm{Ma}$, decrease abruptly from non-metamorphic $(>0.1)$ to metamorphic $(<0.1)$ (Figures 38-39). Grains younger than $\sim 110 \mathrm{Ma}$ are interpreted to have formed in situ during metamorphism or to have experienced lead loss. These grains tend to have mosaic structures, which is indicative of growth during metamorphism (Corfu et al., 2003).

Xenocrystic cores and respective rims were dated separately in 20 zircons (Figure 37) to constrain the timing of metamorphic rim growth. The cores from most of these grains are interpreted as part of the same population as the grains mentioned above that lack cores and rims because the cores do not form a distinct grouping in Figure 37. Metamorphic rim ages occur in three populations: the first ranges from 84-77 Ma with a peak at $80 \mathrm{Ma}(\mathrm{n}=4 ; \mathrm{MSWD}=0.62$; probability of fit $(\mathrm{POF})=0.60)$; the second, from 98-91 Ma with a peak at $95 \mathrm{Ma}(\mathrm{n}=5 ; \mathrm{MSWD}=0.39$; $\mathrm{POF}=0.82)$; and the third, from $110-103 \mathrm{Ma}$ with a peak at $110 \mathrm{Ma}(\mathrm{n}=6 ; \mathrm{MSWD}=0.14 ; \mathrm{POF}=0.98)$. Five of the cores, which are ca. $95 \mathrm{Ma}$, are probably metamorphic as they fall in the middle age population. These three youngest populations have metamorphic $\mathrm{Th} / \mathrm{U}$ ratios $(<0.1)$. The remaining rim ages $(n=5)$ occur in a broad scatter from 168 to 118 Ma with a peak around $140 \mathrm{Ma}(\mathrm{MSWD}=5.2 ; \mathrm{POF}=0.0)$, and have non-metamorphic $\mathrm{Th} / \mathrm{U}$ ratios. 

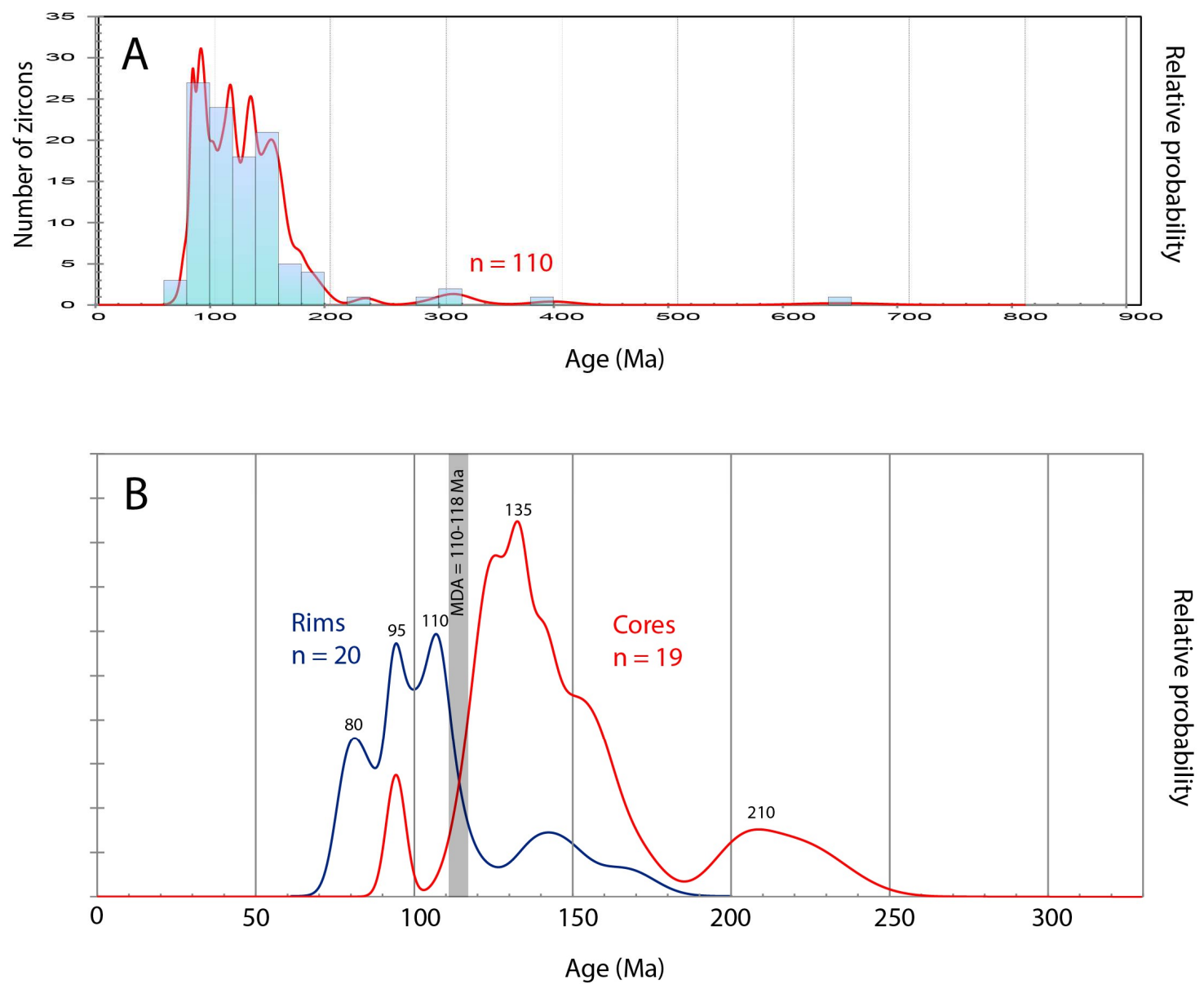

Figure 37. Probability density plots (PDP) for zircons from SG18-025. (A) The PDP for zircons $(\mathrm{n}=110)$, excluding cores and rims. Histogram shows number of zircons. (B) PDP for zircon cores and rims plotted separately. The blue line represents rims, and the red line, cores. The maximum depositional age is between 118-110 Ma. 


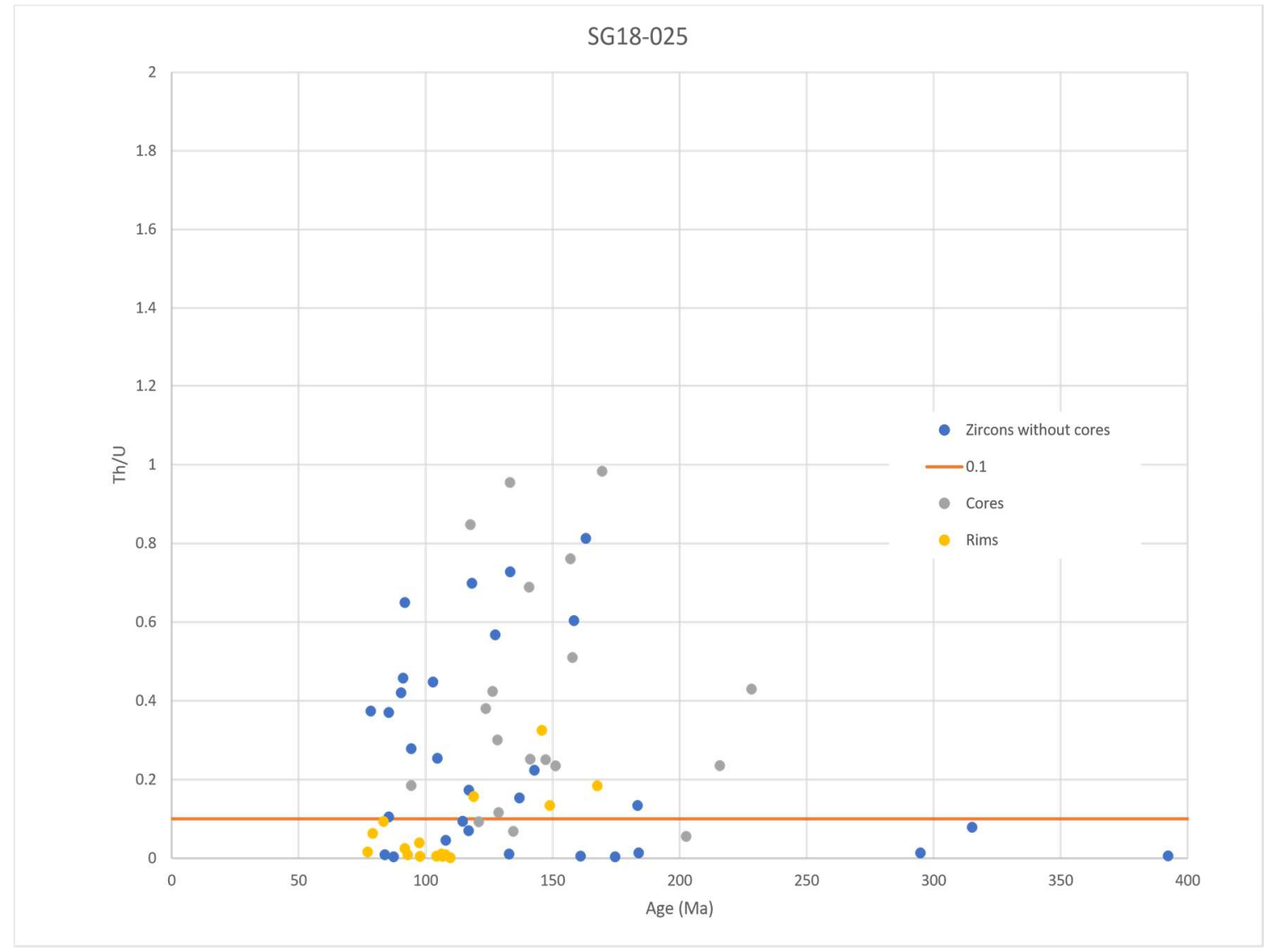

Figure 38. Scatter plot showing Th/U for zircon grains, cores and rims in SG18-025. 


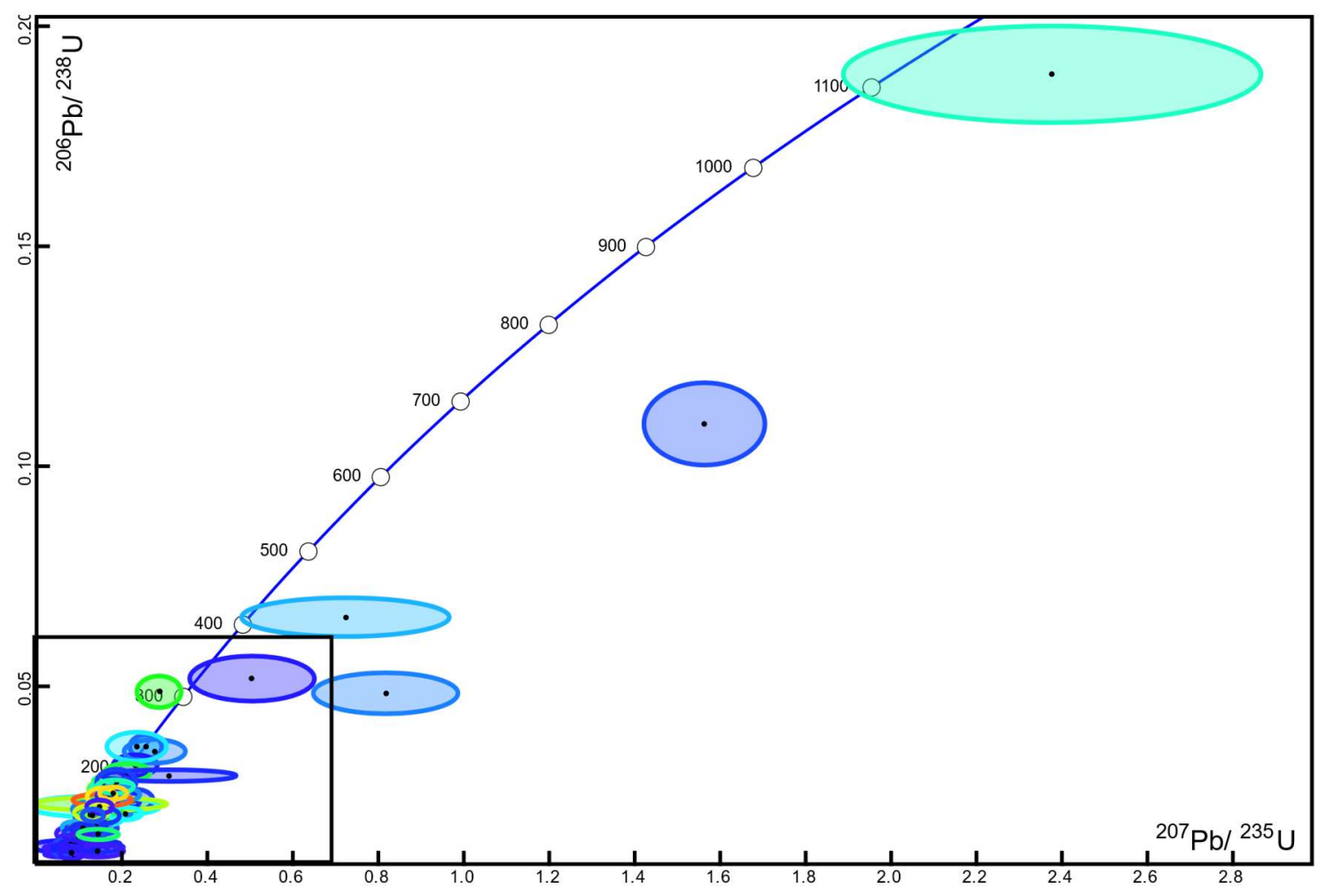

Figure 39. Concordia plot for zircons from SG18-025. Th/U ratios are represented by ellipse color; lower $\mathrm{Th} / \mathrm{U}$ ratios have a bluer color. The black box marks the boundaries of Figure 35. 


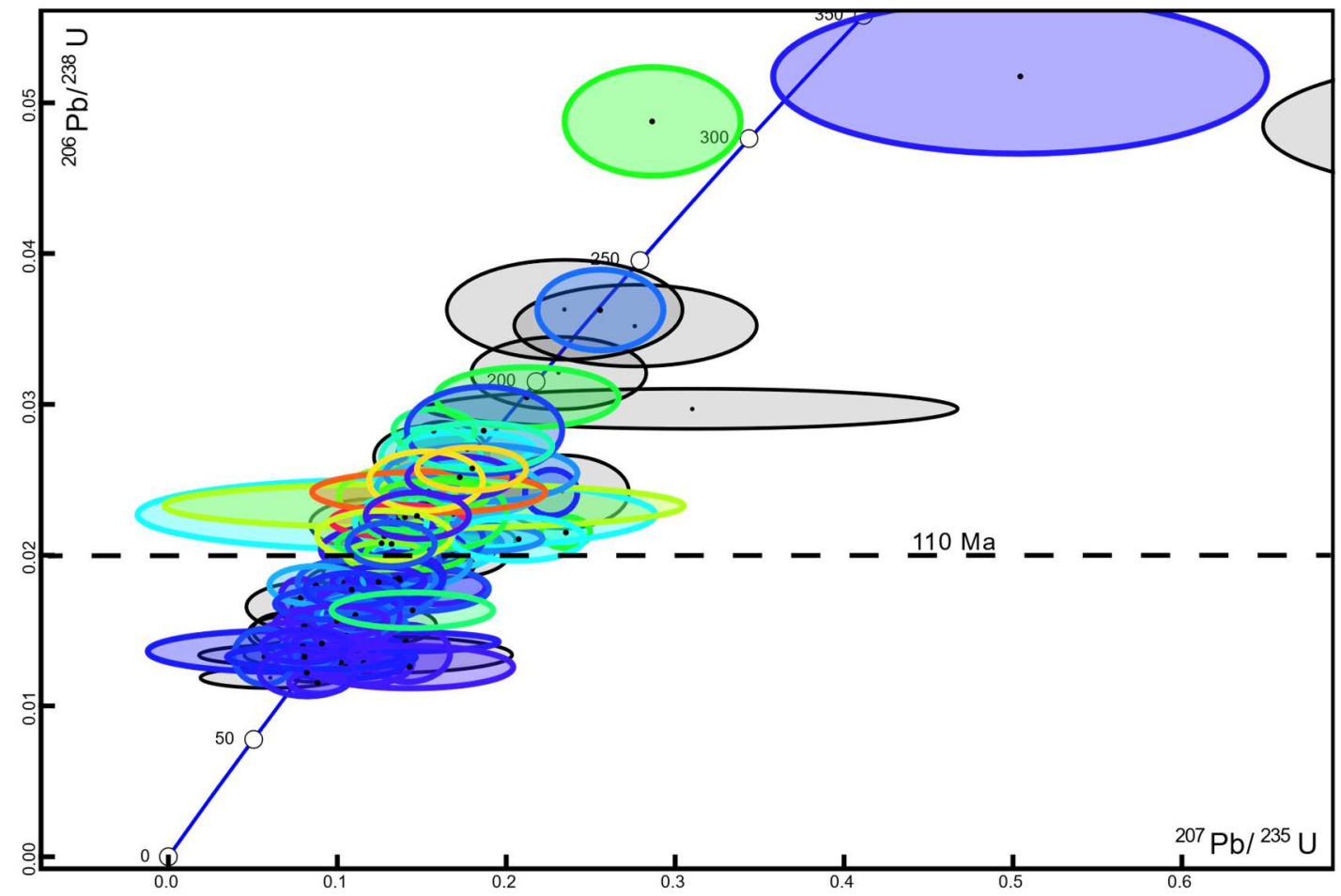

Figure 40. Concordia plot for $<350 \mathrm{Ma}$ zircons from SG18-025. Th/U ratios are represented by ellipse color. Lower $\mathrm{Th} / \mathrm{U}$ ratios have a bluer color. Black line highlights $110 \mathrm{Ma}$, the inferred boundary between detrital and metamorphic zircon. 


\section{DISCUSSION}

\section{Origin of the Spider Glacier Unit}

The mineral assemblages, presence and age of zircons, and rock types provide insight into the origin of the Spider Glacier unit. The most abundant rock type in the Spider Glacier unit, hornblende-biotite gneiss, is likely meta-sedimentary, as it contains zircon with a broad ( $>100 \mathrm{Ma})$ range of ages. The hornblende-biotite gneiss, in general, contains $20-40 \%$ plagioclase, $10-35 \%$ quartz, $15-30 \%$ hornblende and $10-35 \%$ biotite, which agrees best with a protolith of arkosic to lithic arenite.

Biotite gneiss is also interpreted as meta-sedimentary as it commonly forms thin $(<10$ $\mathrm{cm}$ ) interlayers within hornblende-biotite gneiss. Biotite gneiss in one sample has large amounts of plagioclase (45\%) and quartz (45\%), and only minor mafic material $(<10 \%)$. Based on this assemblage, the protolith of the biotite gneiss is likely meta-arkose.

Micaceous quartzite also occurs as thin layers within hornblende-biotite gneiss and biotite gneiss. Mineral separates obtained from one sample of micaceous quartzite lacked zircon. Based on these observations, the micaceous quartzite is interpreted as meta-chert. Micaceous quartzite also tends to interlayer with hornblende gneiss, especially in the northern part of the Spider Glacier area (Figure 7A). The hornblende gneiss is interpreted as meta-basalt or meta-gabbro based on a lack of biotite and quartz, and dominance of plagioclase and hornblende. Meta-peridotite may represent oceanic mantle associated with the protoliths of the meta-basalt and/or meta-gabbro. Alternatively, meta-peridotite may be mantle incorporated into the Spider Glacier unit by later thrusting. 
Igneous material in the Spider Glacier unit, excluding partial melt associated with migmatites, intruded the unit during and after deformation. Hornblende gabbro is largely undeformed, but its occurrence as boudins indicates its intrusion was prior to, or coeval with, deformation. As most of the hornblende gabbro is not deformed, intrusion must have outlasted deformation and/or strain was efficiently focused in the host rocks. Similarly, all the granitoid dikes are undeformed, except for a few with aligned mafic minerals. The two andesitic dikes are undeformed. This leads me to infer that the hornblende gabbro and a small amount of leucocratic granitoid were emplaced coeval with Cretaceous plutons, such as the Entiat or Seven-Fingered Jack plutons, whereas most of the granitic rocks and all of the andesitic dikes was emplaced with younger intrusions, such as the Cloudy Pass batholith.

Based on these interpreted protoliths of the Spider Glacier unit, I propose that the unit was deposited offshore of an arc, in a deep-water environment. This is largely based on the association of meta-basalt and/or meta-gabbro and meta-chert, which presumably were oceanic basalt/gabbro and pelagic chert, respectively. The clastic rocks (e.g. metaarkose, meta-lithic arenite) were deposited on, or imbricated with, the mafic rocks and cherts.

This interpretation raises the question of whether deposition occurred in a fore-arc or back-arc? Comparing the age range of detrital zircons in the Spider Glacier unit with potential zircon sources within the Cordillera does not provide definitive insights (Table 1). If the range of zircon ages in the Spider Glacier unit matched that of a Mesozoic zircon source, then one might infer that the Spider Glacier unit protolith was deposited 
adjacent to that source. The closest arc coeval with the MDA of the unit is the Okanogan Range batholith $\sim 50 \mathrm{~km}$ to the east (Figure 2) (Hurlow and Nelson, 1993), and along strike in southern British Columbia, the Eagle Plutonic Complex ranges from 160-110 Ma (Greig et al., 1991). Three major strike-slip faults (Entiat, Ross Lake, and Pasayten), which likely experienced $>200 \mathrm{~km}$ of slip [see review in Umhoefer and Miller (1996) and Wyld et al., (2006)], lay between the Spider Glacier unit and Okanogan Range batholith (Figure 2), and any connection remains speculative.

Table 1. Zircon age ranges for potential Mesozoic source rocks with ages from 160-110 Ma within the Cordillera.

\begin{tabular}{|c|c|c|}
\hline Early Cretaceous & Age Range (Ma) & References \\
\hline Coast Plutonic Complex & $118-110$ & Gehrels et al. (2009), Cecil et al. (2011) \\
\hline Okanogan Range Batholith & 114-107 & Hurlow and Nelson (1993) \\
\hline Eagle Plutonic Complex & $160-120$ & Greig (1991) \\
\hline Sierra Nevada Batholith & 124-105 & Lackey et al. (2012) \\
\hline Peninsular Range Batholith & $126-110$ & Shaw et al. (2014) \\
\hline \multicolumn{3}{|l|}{ Jurassic } \\
\hline Coast Plutonic Complex & $177-162,157-142$ & Gehrels et al. (2009), Cecil et al. (2011) \\
\hline Blue Mountains & $170-150$ & LaMaskin et al. (2015) \\
\hline Klamath Mountains & $180-140$ & Harper and Wright (1984) \\
\hline Sierra Nevada Batholith & $180-150$ & Chapman et al. (2012) \\
\hline Transverse Ranges & $180-140$ & Needy et al. (2009) \\
\hline \multicolumn{3}{|l|}{ Jurassic to Cretaceous } \\
\hline Spider Glacier unit & $\sim 160-110$ & This study \\
\hline
\end{tabular}

Note: Modified from Sauer et al. (2017a). 
Rather than matching detrital zircons with potential source rocks, many studies use zircon age ranges and distinct age peaks as fingerprints to correlate sedimentary rock units, and make inferences about source regions (e.g., Lamaskin, 2012; Sharman et al., 2015; Sauer et al., 2017a). I compared the Spider Glacier unit zircon age pattern with those in clastic rocks to the east and west of the Cascades core (Table 2).

A similar range of zircon ages and age peaks as the Spider Glacier unit is found in the Winthrop Formation of the Methow basin. This Formation was deposited in a fore-arc basin, but subsequent sinistral shear may have transported the basin into a back-arc position during 96-45 Ma magmatism in the North Cascades (e.g. Monger et al., 1994). The Winthrop Formation has zircon ages which generally range from 180-100 Ma, roughly matching the 165-110 Ma age range of zircons in the Spider Glacier unit. Age peaks in the Winthrop Formation occur at 165, 150 and 120-110 Ma (DeGraaff-Surpless et al., 2003). The age peak of $\sim 130$ Ma seen in the Spider Glacier unit is absent. There are other significant differences between the protoliths of the Spider Glacier unit and the Winthrop Formation, as no meta-peridotites, meta-basalts or meta-cherts directly underlie or have been found in the Winthrop Formation.

Another unit which has a broadly similar range of detrital zircon ages ( $180-110 \mathrm{Ma})$ as the Spider Glacier unit is the lithic petrofacies of the western mélange belt, which is exposed west of the Cascades core (Figure 2) (Sauer et al., 2017a). This belt has age peaks at 180,160, and $110 \mathrm{Ma}$ (Sauer et al., 2017a). This qualitative similarity of zircon age ranges and peaks between rock units deposited in the fore-arc and the Spider Glacier unit at least agrees with deposition of the Spider Glacier unit in a fore-arc setting. 
Moreover, meta-peridotites, meta-basalts, and meta-cherts are found within, or in tectonic contact with the western mélange belt of the fore-arc.

The lack of Proterozoic zircons in the Spider Glacier unit further supports deposition of the Spider Glacier unit protolith in a fore-arc setting, as a barrier must have prevented cratonic zircons flowing from the east. One would expect cratonic zircons to flow readily into a back-arc, whereas a high-elevation continental arc would prevent cratonic zircons from reaching a fore-arc. Therefore, as the Spider Glacier unit lacks Proterozoic zircon, the protolith was most likely deposited in a fore-arc setting.

Table 2. Zircon age data for back-arc, fore-arc and accretionary wedge units in the North Cascades. The MDAs, main age peaks, and number of zircons $(n=27-417)$ for units adjacent to the Cascades core are listed.

\begin{tabular}{|c|c|c|c|c|}
\hline Unit & Rock Type & Number of zircons & Main peaks (Ma) & MDA (Ma) \\
\hline \multicolumn{5}{|l|}{ Back-arc } \\
\hline Pasayten Group (Winthrop Formation) & Arkosic sandstone & 417 & $180,160,120-110$ & $105 \pm 2$ \\
\hline Newby Group (Twisp Formation) & Arkosic Sandstone & 27 & 156 & $152 \pm 3$ \\
\hline Ladner Group (Boston Bar Formation) & Volcaniclastic sandstone & 100 & 170 & $165 \pm 4$ \\
\hline \multicolumn{5}{|l|}{ Fore-arc } \\
\hline Nooksack Formation & Fine-grained sandstone & 114 & 155 & $145 \pm 3$ \\
\hline \multicolumn{5}{|l|}{ Western Melange Belt Unit } \\
\hline Arkosic Petrofacies & Arkosic Sandstone & 129 & $1700,1400,190,165,90,74$ & $72 \pm 2$ \\
\hline Lithic Petrofacies & Lithic sandstone & 145 & $180,160,110$ & $109 \pm 3$ \\
\hline \multicolumn{5}{|l|}{ Unknown Setting } \\
\hline Spider Glacier unit & Hornblende-biotite gneiss & 110 & 130,120 & $118-110$ \\
\hline
\end{tabular}

Note: Modified from Sauer et al. (2017a). 


\section{Burial Mechanism}

Zircon metamorphic rim ages provide some insight into how and at what rate the Spider Glacier unit protolith was buried within the arc. The metamorphic rims occur in four populations. The youngest three populations each span $\sim 7-10 \mathrm{Ma}$ and are interpreted to correlate with periods of metamorphism. The two youngest zircon rim populations, 84-77 Ma $(\mathrm{n}=4)$ and 98-91 Ma $(\mathrm{n}=5)$, overlap with known periods of high-grade metamorphism in the Cascades crystalline core (e.g., Evans and Berti, 1986; Stowell et al., 2007). In contrast, the population ranging from 110-103 Ma in age $(n=6)$ does not overlap with any known metamorphism in the Cascades core and hints at metamorphism initiating before the onset of 96 Ma plutonism. The oldest zircon rim population $(\mathrm{n}=5)$ ranges from $168-118 \mathrm{Ma}$ and is also not a period of well-documented metamorphism. These older grains, however, may be inherited or be the result of overlap between the core and rim during ablation.

If the inferred metamorphic rims in the Spider Glacier unit are in situ, then the Spider Glacier unit was buried and metamorphosed in $<1$ Ma to 8 Ma following deposition. Preliminary hornblende-garnet thermobarometry suggests the Spider Glacier unit reached $\sim 30 \mathrm{~km}$ of depth $\left(8.7 \pm 1.4 \mathrm{kbar}, 590-670^{\circ} \mathrm{C}\right.$; A. Hansen, written communication), which requires burial rates between $\sim 3.5->30 \mathrm{~mm}$ per year. Though the exact rate is uncertain, burial appears to have been rapid. The faster burial rate would support burial in a subduction zone, rather than in a fore-arc or back-arc setting, as vertical movement on fold and thrust belts is comparatively slow (3.5 mm/year) (e.g., Mazzoti and Hyndman, 2002). 


\section{Anomalous Folds}

Most folds in the Cascades core trend north and northwest, or south and southeast and plunge shallowly (see summary in Miller et al., 2006). In contrast, the folds in the Spider Glacier unit and Holden assemblage in the Carne Mountain area have moderate to steep plunge, and a highly variable, average westward trend. The origin of these folds is uncertain. They may have formed in a typical Cascades orientation and been rotated by Eocene movement on the Entiat fault. This scenario is not well supported, as the shortest rotation of $30-60^{\circ}$ would require sinistral slip and counter-clockwise rotation in the Entiat fault zone, which conflicts with observations by other workers that support dextral slip (e.g., Tabor et al., 1987). Rotation via dextral slip would need to be $>100^{\circ}$, which seems unlikely.

Alternatively, the anomalously oriented folds could record deformation that is older than most of the folds in the core of the Cascades. Unfortunately, the timing of folding in the Spider Glacier unit is not sufficiently constrained to evaluate this hypothesis. Thus, the folding in the Spider Glacier unit remains enigmatic. It is, however, helpful in investigating the contact between the Spider Glacier unit and the adjacent Swakane Gneiss.

\section{Chiwawa Discontinuity}

A major goal of this study was to investigate the contact between the Spider Glacier unit and the Swakane Gneiss. The results show that the Swakane Gneiss lacks the moderately to steeply plunging, variably oriented, overall west-trending folds in the Spider Glacier unit. Thus, the contact separates rock units with different rock types that 
deformed very differently, and this lack of strain compatibility across the contact implies that it is tectonic.

There is also an apparent age difference across the contact, inferred from MDAs calculated from detrital zircons. The Swakane Gneiss (hanging wall) has MDAs ranging from 93-81 Ma (Sauer et al., 2019), and has interpreted in situ zircon metamorphic rim populations between 78-68 Ma (Sauer et al., 2017a). The Spider Glacier unit (footwall) has an older MDA of ca. 118-110 Ma and has zircon rim populations of ca. 110, 95, 85 and $80 \mathrm{Ma}$. If the rims in the Spider Glacier unit formed in situ, then metamorphism of the Spider Glacier unit began prior to deposition of the Swakane Gneiss, and probably continued during deposition of the Gneiss. This requires that the Chiwawa discontinuity juxtaposes younger material above older material.

Quartz LPO patterns provide some insight about the kinematics of movement along the Chiwawa discontinuity. The quartz LPOs from the sample collected in the Spider Glacier unit $<10 \mathrm{~m}$ from the Chiwawa discontinuity (SG17-114) define a type-I crossed girdle, which is indicative of low- to medium-temperature, non-coaxial strain. The asymmetry of the crossed girdle and orientation of a-axes maxima along the primitive circle, combined with foliation and lineation orientation, imply top-to-the-east-southeast shear (Bouchez, 1978; see review in Passchier and Trouw, 2008). This pattern contrasts with the sample collected $\sim 100 \mathrm{~m}$ from the Chiwawa discontinuity (SG17-235.2), where quartz LPOs form a weak type-II crossed girdle indicative of coaxial strain (see review in Passchier and Trouw, 2008), and a z-axis maximum indicative of prismatic $\{\mathrm{m}\}<\mathrm{a}>$ slip in quartz and active only at temperatures greater than $\sim 550^{\circ} \mathrm{C}$ (Law et al., 1990). This 
sample farther from the Chiwawa discontinuity likely records coaxial strain related to foliation formation, rather than movement along the discontinuity. In summary, the Chiwawa discontinuity is probably a shear zone, but it is not associated with welldeveloped kinematic indicators in the field. Based on the quartz LPOs from SG17-114, sampled near the discontinuity, and the oblique orientation of the lineation at that location, the shear zone likely accommodated top-to-the-east-southeast, sinistral-reverse motion. This movement would thrust Swakane Gneiss on the Spider Glacier unit.

\section{Original Position of Spider Glacier Unit Relative to the Swakane Gneiss}

A fundamental question of this study is whether the Spider Glacier unit is beneath the Swakane Gneiss in the Cascades crustal section. The Spider Glacier unit, in its present position, is below the Gneiss based on my mapping. As the contact between them (the Chiwawa discontinuity) records ductile strain, it was clearly active prior to local brittle deformation (Figure 6 and 7) along the Entiat fault. This brackets activity along the Chiwawa discontinuity to between $81 \mathrm{Ma}$, the youngest MDA of the Swakane Gneiss, and the Eocene, the earliest documented movement along the Entiat fault.

As to the original relative position of the two units, quartz LPO patterns near the Chiwawa discontinuity allow for speculation. If quartz LPOs from the sample of Spider Glacier unit closest to the Chiwawa discontinuity (SG17-114) accurately record displacement along the discontinuity, then it accommodated oblique thrusting of the Swakane Gneiss over the Spider Glacier unit. However, the question remains of when did this thrusting occur? The post-81 Ma age of thrusting indicates that the juxtaposition of the two units is too young to be part of the regional Northwest Cascades - San Juan 
Islands thrust system (e.g., Misch, 1966; Brown, 1987; Brandon et al., 1988; McGroder, 1991; Brown et al., 2005). The thrusting may be associated with 74-65 Ma metamorphism and ductile deformation of the Swakane Gneiss (Gatewood and Stowell, 2012; Sauer et al., 2017a), which presumably was related to underthrusting of the Gneiss into the arc. I propose that, as the Swakane Gneiss protolith was buried during underthrusting, a backthrust placed it above the older Spider Glacier unit, which had already been accreted, folded and incorporated deeply into the North Cascades continental magmatic arc.

\section{Spider Glacier Unit: Part of the Holden Assemblage?}

Cater and Crowder (1967) mapped the Spider Glacier unit as Holden assemblage whereas Haugerud et al. (2009) show it as Napeequa complex. As noted above, the Napeequa complex is older than the Spider Glacier unit making this correlation unlikely. This study and others (e.g., Gordon et al., 2017; Sauer et al., 2017a; Schermer, 2017) have shown that the Holden assemblage and correlative Cascade River Schist range from Late Permian to mid-Cretaceous in age. The MDA of the Spider Glacier unit overlaps with that of the younger part of the Cascade River-Holden assemblage. The Spider Glacier unit is overall more mafic than the Holden assemblage in the Holden Village area, but is relatively like the more mafic rocks of the assemblage in the Carne Mountain area. The major difference between the Holden assemblage and the Spider Glacier unit is the absence of marble in the Spider Glacier unit and meta-peridotite in the Holden assemblage. The Spider Glacier unit may represent a previously unrecognized unit of uncertain relationship to the Holden assemblage. However, considering the overall 
heterogeneity of the Holden assemblage, these differences seem inadequate to separate the Spider Glacier unit as distinct from the Holden assemblage. Therefore, I propose that the Spider Glacier unit is a more mafic and oceanic part of the Cascade River-Holden assemblage.

\section{Cascade River-Holden Arc}

Recent data show that the Cascade River-Holden assemblage belt ranges in age from Late Permian to Late Cretaceous (this study; Gordon et al., 2017; Schermer, 2017), but no rocks between $118 \mathrm{Ma}$ and $220 \mathrm{Ma}$ in age have been identified, and the PermoTriassic and Cretaceous components of the belt are probably separated by a fault or unconformity. If the Spider Glacier unit is included as part of the Holden assemblage, then it supports a fault contact between the older and younger components of the assemblage, as it seems unlikely that meta-chert and meta-basalt (Spider Glacier unit) would accumulate on probable arc rocks (Holden assemblage in Holden Village), and more likely that they would be juxtaposed by faulting.

The extent of Late Permian Cascade River-Holden arc rocks is partially informed by this study and others. Schermer (2017; written communication) interpreted a Late Permian $(263.5 \pm 2.3 \mathrm{Ma})$ crystallization age for orthogneiss in the Cascade River Schist roughly $33 \mathrm{~km}$ to the northwest $\left(320^{\circ}\right)$ of where sample SG17-068.2 was collected in the Holden Village area. This suggests that a belt of Late Permian Cascade River-Holden rocks extends at least that distance.

Other rocks in the Cordillera may be part of the same Permian arc as the Cascade River-Holden assemblage. Schermer (2017) interpreted the Wallowa terrane (part of Blue 
Mountains terrane on Figure 1) of northeastern Oregon and western Idaho as a potential correlative to the Late Permian arc rocks found northwest of Holden Village. The Wallowa terrane is dominated by Permian to Triassic volcanic and volcaniclastic rocks of the Seven Devils Group, which are underlain by Paleozoic arc basement of the Cougar Creek complex (Vallier, 1977; Vallier et al., 2016). If the Wallowa terrane and Cascade River-Holden assemblage are cogenetic, then the older rocks of the Holden assemblage would most likely correlate with the Hunsaker Creek Formation of Vallier (1977) of the Wallowa terrane, which contains sandstones, argillites, tuffs, intermediate to mafic volcanic rocks, and rare limestones.

The Cascade River-Holden assemblage may also correlate with the Wineglass and Kutcho assemblages of British Columbia (Figure 1). The Wineglass and Kutcho assemblages, which were correlated by Schiarizza (2013), consist of Permian to Triassic granitoid overlain by mafic to felsic volcanic rocks of similar age. The Holden assemblage would best correlate with the upper volcanic unit of the Wineglass assemblage (Wv2), which consists of rhyolites, basalts and volcanic breccias.

\section{CONCLUSIONS}

The major conclusions from this study are as follows.

1. Based on the mineral assemblages and modes of the Spider Glacier unit, the protolith was lithic to arkosic arenite, chert, basalt and/or gabbro. The presence of meta-chert and the mafic rocks suggests that the protolith was likely deposited in a deep-water environment.

2. By comparing the detrital zircon age range and age peaks in the Spider Glacier 
unit with those of other units in the fore-arc and back-arc, the Spider Glacier unit was deposited in a fore-arc setting.

3. The U-Pb dates of detrital zircons, are interpreted to indicate that the protolith of the Spider Glacier unit was deposited between $\sim 118-110 \mathrm{Ma}$, and was subjected to metamorphic conditions capable of producing zircon rim growth perhaps as early as ca. $110 \mathrm{Ma}$.

4. The Spider Glacier unit and the Holden assemblage in the Carne Mountain area are folded by moderately to steeply plunging, highly-variably trending folds that have a mean westward trend. The folds may have originally formed with a northwest-southeast trend and later been rotated within the Entiat fault zone, or, more likely, they record an early deformation event in the Cascades core.

5. A tectonic contact, the Chiwawa discontinuity, separates the Spider Glacier unit and Swakane Gneiss, based on strain incompatibility and a difference in rock types and MDAs across the contact. According to quartz LPO patterns from one location, the discontinuity accommodated top-to-the-east-southeast sinistralreverse shear placing the Swakane Gneiss over the Spider Glacier unit.

6. The Spider Glacier unit was deposited in a fore-arc setting, accreted to the arc, folded, and metamorphosed, prior to the Swakane Gneiss being deposited. The Gneiss was thrust over the older Spider Glacier unit along a back thrust.

7. The Cascade River-Holden assemblage contains rocks of Late Permian age, which are part of a belt of Late Permian rocks extending at least $33 \mathrm{~km}$ to the northwest within the Cascades core. 


\section{REFERENCES}

Beck, M.E.J., Burmester, R.F., and Schoonover, R., 1981, Paleomagnetism and tectonics of the Cretaceous Mt. Stuart Batholith of Washington: translation or tilt?: Earth and Planetary Science Letters, v. 56, p. 336-342.

Behn, M.D., Kelemen, P.B., Hirth, G., Hacker, B.R., and Massone, H., 2011, Diapirs as the source of the sediment signature in arc lavas: Nature Geoscience, v. 4, p. 641-646.

Bouchez, J.L., 1978, Preferred orientations of quartz $<\mathrm{a}>$ axes in some tectonites: kinematic inferences: Tectonophysics, v. 49, p. T25-T30.

Boysun, M.A., 2004, Partial melting, melt collection and transport in the Swakane Gneiss, North Cascades crystalline core, Washington [M.S. thesis]: Los Angeles, University of Southern California, $86 \mathrm{p}$.

Brandon, M.T., Cowan, D.S., and Vance, J.A., 1988, The Late Cretaceous San Juan Thrust system, San Juan Islands, Washington: Geological Society of America Special Paper 221, 81 p., doi:10.1130/SPE221-p1.

Brown, E.H., 1987, Structural geology and accretionary history of the Northwest Cascades system, Washington and British Columbia: Geological Society of America Bulletin, v. 99, p. 201-214.

Brown, E.H., and Talbot, J.L., 1989, Orogen-parallel extension in the North Cascades crystalline core, Washington: Tectonics, v. 8, p. 1105-1114.

Brown, E.H., Cary, J.A., Dougan, D.B, Dragovich, J.D., Fluke, S.M., and McShane, D.P., 1994, Tectonic evolution of the Cascades crystalline core in the Cascade River Area, Washington: Washington Division of Geology and Earth Resources Bulletin, v. 80, p. 93-113.

Brown, E.H., Lapen, T.J., Leckie, R.M., Premoli Silva, I., Verge, D., and Singer, B.S., 2005, Revised ages of blueschist metamorphism and the youngest pre-thrusting rocks in the San Juan Islands, Washington: Canadian Journal of Earth Sciences, v. 42, p. 1389 1400.

Cater, F.W., 1982, Intrusive rocks of the Holden and Lucerne quadrangles, Washingtonthe relation of depth zones, composition, textures, and emplacement of plutons: U.S. Geological Survey Professional Paper 1220, 115 p.

Cater, F.W., and Crowder, D.F., 1967, Geologic map of the Holden quadrangle, Snohomish and Chelan counties, Washington: U.S. Geological Survey, Map GQ-646, scale 1:62,500. 
Cater, F.W., and Wright, T.L., 1967, Geologic map of the Lucerne quadrangle, Chelan county, Washington: U.S. Geological Survey, Map GQ-647, scale 1:62,500.

Cecil, M.R., Gehrels, G.E., Ducea, M.N., and Patchett, P.J., 2011, U-Pb-Hf characterization of the central Coast Mountains batholith: implications for petrogenesis and crustal architecture: Lithosphere, v. 3, p. 247-260.

Chapman, A.D., 2016, The Pelona-Orocopia-Rand and related schists of southern California: a review of the best known archive of shallow subduction on the planet: International Geology Review, v. 59, p. 664-701.

Chapman, A.D., Luffi, P.I., Saleeby, J.B., and Petersen, S., 2011, Metamorphic evolution, partial melting and rapid exhumation above an ancient flat slab: insights from the San Emigdio Schist, southern California: Journal of Metamorphic Geology, v. 29, p. 601626.

Corfu, F., Hanchar, J.M., Hoskin, P.W.O., and Kinny, P., 2003, Atlas of zircon textures: Reviews in Mineralogy and Geochemistry, v. 53, p. 469-500.

Crowder, D.F., Tabor, R.W., and Ford, A.B., 1966, Geologic Map of the Glacier Peak Quadrangle, Snohomish and Chelan Counties, Washington: U.S. Geological Survey Map GQ-473, scale 1:62,500.

DeCelles, P.G., Ducea, M.N, Kapp, P., and Zandt, G., 2009, Cyclicity in Cordilleran orogenic systems: Nature Geoscience, v. 2, p. 251-257.

Degraaff-Surpless, K., Mahoney, J.B., Wooden, J.L., and McWilliams, M.O., 2003, Lithofacies control in detrital zircon provenance studies: insights from the Cretaceous Methow basin, Southern Canadian Cordillera: Geological Society of America Bulletin, v. 115, doi: 10.1130/B25267.1.

Ducea, M.N., and Barton, M.D., 2007, Igniting flare-up events in Cordilleran arcs: Geology, v. 35, p. 1047-1050.

Dragovich, J.D., and Derkey, R.E., 1994, A Late Triassic island-arc setting for the Holden volcanogenic massive sulfide deposit, North Cascades, Washington: Washington Geology, v. 22, p. 28-37.

Eddy, M.P., Bowring, S.A., Umhoefer, P.J., Miller, R.B., McLean, N.M., and Donaghy, E.E., 2016, High-resolution temporal and stratigraphic record of Siletzia's accretion and triple junction migration from nonmarine sedimentary basins in central and western Washington: Geological Society of America Bulletin, v.128, p. 425-441. 
Evans, B.W., and Berti, J.W., 1986, Revised metamorphic history of the Chiwaukum Schist, North Cascades, Washington: Geology, v. 14, p. 695-698.

Gatewood, M.P., and Stowell, H.H., 2012, Linking zircon U-Pb and garnet Sm-Nd ages to date loading and metamorphism in the lower crust of a Cretaceous magmatic arc, Swakane Gneiss, WA, USA: Lithos, v. 146-147, p. 128-142.

Gordon, S.M., Bowring, S.A., Whitney, D.L., Miller, R.B., and McLean, N., 2010, Time scales of metamorphism, deformation, and crustal melting in a continental arc, North Cascades, USA: Geological Society of America Bulletin, v. 122, p. 1308-1330.

Gordon, S.M., Miller, R.B., and Sauer, K.B., 2017, Incorporation of sedimentary rocks into the deep levels of continental magmatic arcs: links between the North Cascades arc and surrounding sedimentary terranes, in Haugerud, R.A., and Kelsey, H.M., eds., From the Puget Lowland to East of the Cascade Range: Geologic Excursions in the Pacific Northwest: Geological Society of America, Field Guide 49, p. 101-142.

Gehrels, G., Rusmore, M., Woodsworth, G., Crawford, M., Andronicos, C., Hollister, L., Patchett, J., Ducea, M., Butler, R., Klepeis, K., Davidson, C., Mahoney, B., Friedman, R., Haggart, J., Crawford, W., Pearson, D., and Girardi, J., 2009, U-Th-Pb geochronology of the Coast Mountains batholith in north-coastal British Columbia: constraints on age, petrogenesis, and tectonic evolution: Geological Society of America Bulletin, v. 121, p. $1341-1361$.

Greig, C.J., 1991, Jurassic and Cretaceous plutonic and structural styles of the Eagle Plutonic Complex, southwestern British Columbia, and their regional significance: Canadian Journal of Earth Sciences, v.29, p. 793-811.

Grove, M., Jacobson, C.E., and Barth, A.P., 2003, Temporal and spatial trends of Late Cretaceous-early Tertiary underplating of Pelona and related schist beneath southern California and southwestern Arizona, in Johnson, S.E., et al., eds., Tectonic Evolution of Northwestern México and the Southwestern USA: Geological Society of America Special Paper 374, p. 381-406.

Hacker, B.R., Kelemen, P.B., and Behn, M.D., 2011, Differentiation of continental crust by relamination: Earth and Planetary Science Letters, v. 307, p. 501-516.

Harper, G.D., and Wright, J.E., 1984, Middle to Late Jurassic tectonic evolution of the Klamath Mountains, California-Oregon: Tectonics, v. 3, p. 759-772.

Haugerud, R.A., and Tabor, R.W., 2009, Geologic map of the North Cascades: U.S Geological Survey, Scientific Investigations Map 2640, scale 1:200,000. 
Haugerud, R.A., Van der Heyden, P., Tabor, R.W., Stacey, J.S., and Zartman, R.E., 1991, Late Cretaceous and early Tertiary plutonism and deformation in the Skagit Gneiss Complex, North Cascades Range, Washington and British Columbia: Geological Society of America Bulletin, v. 103, p. 1297-1307.

Haxel, G., and Dillon, J., 1978, The Pelona Orocopia Schist and Vincent-Chocolate Mountain thrust system, southern California, in Howell, D.G., and McDougall, K.A., eds., Mesozoic Paleogeography of the Western United States: Pacific Section, Society of Economic Paleontologists and Mineralogists, Pacific Coast Paleogeography Symposium, v. 2, p. 453-469.

Hirth, G., and Tullis, J., 1992, Dislocation creep regimes in quartz aggregates: Journal of Structural Geology, v. 14, p. 145-159.

Hunter, N.J.R., Weinberg, R.F., Wilson, C.J.L., and Law, R.D., 2018, A new technique for quantifying symmetry and opening angles in quartz c-axis pole figures: implications for interpreting the kinematic and thermal properties of rocks: Journal of Structural Geology, v. 112, p. 1-6.

Hurban, G.K., 1991, Fabric study and structural history of deformed plutonic and metamorphic rocks in the Holden area, North Cascades, Washington [M.S. thesis]: Bellingham, Western Washington University, 96 p.

Hurlow, H.A., and Nelson, B.K., 1993, U-Pb zircon and monazite ages for the Okanogan Range batholith, Washington: implications for the magmatic and tectonic evolution of the southern Canadian and northern United States Cordillera: Geological Society of America Bulletin, v. 105, p. 231-240.

Journeay, J.M., and Friedman, R.M., 1993, The Coast Belt thrust system: evidence of Late Cretaceous shortening in southwest British Columbia: Tectonics, v. 12, p. 756-775.

Lackey, J.S., Cecil, M.R., Cameron, J.W., Bindeman, I.N., and Gehrels, G.E., 2012, The Fine Gold Intrusive Suite: the roles of basement terranes and magma source development in the Early Cretaceous Sierra Nevada batholith: Geosphere, v. 8, p. 292-313.

LaMaskin, T.A., 2012, Detrital zircon facies of Cordilleran terranes in western North America: GSA Today, v. 22, p. 4-11.

LaMaskin, T.A., Dorsey, R.J., Vervoort, J.D., Schmitz, M.D., Tumpane, K.P., and Moore, N.O., 2015, Westward growth of Laurentia by pre-Late Jurassic terrane accretion, eastern Oregon and western Idaho, United States: The Journal of Geology, v. 123, p. 233-267. 
Law, R.D., Schmid, S.M., and Wheeler, J., 1990, Simple shear deformation and quartz crystallographic fabrics: a possible natural example from the Torridon area of NW Scotland: Journal of Structural Geology, v. 12, p. 29-45.

Lister, G.S., 1977, Discussion: crossed-girdle c-axis fabrics in quartzites plastically deformed by plane strain and progressive simple shear: Tectonophysics, v. 39, p. 51-54.

Loewen, M.W., and Kent, A.J.R., 2012, Sources of elemental fractionation and uncertainty during the analysis of semi-volatile metals in silicate glasses using LA-ICPMS: Journal of Analytical Atomic Spectrometry, v. 27, p. 1502-1508.

Mattinson, J.M., 1972, Ages of zircons from the North Cascades mountains, Washington: Geological Society of America Bulletin, v. 83, p. 3769-3784.

Matzel, J.E.P., Bowring, S.A., and Miller, R.B., 2004, Protolith age of the Swakane Gneiss, North Cascades, Washington: evidence of rapid underthrusting of sediments beneath an arc: Tectonics, v. 23, doi: 10.1029/2003TC001577.

Mazzoti, S., and Hyndman, R.D., 2002, Yakutat collision and strain transfer across the northern Canadian Cordillera: Geological Society of America, v. 30, p. 495-498.

McGroder, M.F., 1991, Reconciliation of two-sided thrusting, burial metamorphism, and diachronous uplift in the Cascades of Washington and British Columbia: Geological Society of America Bulletin, v. 103, p. 189-209.

Miller, R.B., and Bowring, S.A., 1990, Structure and chronology of the Oval Peak batholith and adjacent rocks: implications for the Ross Lake fault zone, North Cascades, Washington: Geological Society of America Bulletin, v. 102, p. 1361-1377.

Miller, R.B., and Paterson, S.R., 2001, Influence of lithological heterogeneity, mechanical anisotropy, and magmatism on the rheology of an arc, North Cascades, Washington: Tectonophysics, v. 342, p. 351-370.

Miller, R.B., and Snoke, A.W., 2009, The utility of crustal cross sections in the analysis of orogenic processes in contrasting tectonic settings, in Miller, R.B., and Snoke, A.W., eds., Crustal cross sections from the western North America Cordillera and elsewhere: implications for tectonic and petrologic processes: Geological Society of America Special Paper 456, p. 1-38.

Miller, R.B., Haugerud, R.H., Murphy, F., and Nicholson, L.S., 1994, Tectonostratigraphic framework of the northeastern Cascades: Washington Division of Geology and Earth Resources Bulletin 80, p. 73-92. 
Miller, R.B., Matzel, J.P., Paterson, S.R., and Stowell, H.H., 2003, Cretaceous to Paleogene Cascades arc: structure, metamorphism, and time scales of magmatism, burial, and exhumation of a crustal section, in Swanson, T., ed., Western Cordillera and Adjacent Areas: Boulder, Colorado, Geological Society of America, Field Guide 4, p. $107-135$.

Miller, R.B., Paterson, S.R., Lebit, H., Alslben, H., and Luneburg, C., 2006, Significance of composite lineations in the mid- to deep crust: a case study from the North Cascades, Washington: Journal of Structural Geology, v. 28, p. 302-322.

Miller, R.B., Gordon, S.M., Bowring, S., Doran, B., McLean, N., Michels, Z., Shea, E., and Whitney, D.L., 2016, Linking deep and shallow crustal processes during regional transtension in an exhumed continental arc, North Cascades, northwestern Cordillera [USA]: Geosphere, v. 12, p. 900-924.

Misch, P., 1966, Tectonic evolution of the northern Cascades of Washington State, in Gunning, H.C., ed., A symposium on the tectonic history and mineral deposits of the western Cordillera in British Columbia and neighboring parts of the United States: Canadian Institute of Mining and Metallurgy Special Volume 8, p. 101-148.

Misch, P., 1968, Plagioclase compositions and non-anatectic origin of migmatitic gneisses in northern Cascade mountains of Washington State: Contributions to Mineralogy and Petrology, v. 17, p. 1-70.

Monger, J.W.H., and Brown, E.H., 2016, Tectonic evolution of the southern CoastCascades orogen, northwestern Washington and southwestern British Columbia, in Cheney, E.S., ed., The geology of Washington and beyond: from Laurentia to Cascadia: Seattle, University of Washington Press, p. 101-130.

Monger, J.W.H., and Gibson, D.G., 2019, Mesozoic-Cenozoic deformation in the Canadian Cordillera: the record of a "continental bulldozer"?: Tectonophysics, v. 757, p. $153-169$.

Monger, J.W.H., van der Heyden, P., Journeay, J.M., Evenchick, C.A., and Mahoney, J.B., 1994, Jurassic-Cretaceous basins along the Canadian Coast Belt: their bearing on pre-mid-Cretaceous sinistral displacements: Geology, v.22, p.175-178.

Needy, S.K., Anderson, J.L., Wooden, J.L., Fleck, R.J., Barth, A.P., Paterson, S.R., Memeti, V., and Pignotta, G.S., 2009, Mesozoic magmatism in an upper- to middlecrustal section through the Cordilleran continental margin arc, eastern Transverse Ranges, California, in Miller, R.B., and Snoke, A.L., eds., Crustal cross sections from the western North American Cordillera and elsewhere: implications for tectonic and petrologic processes: Geological Society of America Special Paper 456, p. 187-218. 
Otamendi, J.E., Vujovich, G.I., De la Rosa, J.D., Tibaldi, A.M., Castro, A., Martino, R.D., and Pinotti, L.P., 2008, Geology and petrology of a deep-crustal zone from the Famatinian paleo-arc, Sierras de Valle Fetril and La Huerta, San Juan, Argentina: Journal of South American Earth Sciences, v. 27, p. 258-279.

Paterson, S.R., Miller, R.B., Alsleben, H., Whitney, D.L., Valley, P.M., and Hurlow, H., 2004, Driving mechanisms for $>40 \mathrm{~km}$ of exhumation during contraction and extension in a continental arc, Cascade core, Washington: Tectonics, v. 23, doi:10.1029/2002TC001440.

Passchier, C.W, and Trouw, R.A.J., 2008, Microtectonics: Germany, Springer-Verlag Berlin Heidelberg Press, 366 p.

Rubin, C.M., Saleeby, J.B., Cowan, D.S., Brandon, M.T., and McGroder, M.F., 1990, Regionally extensive mid-Cretaceous west-vergent thrust system in the northwestern Cordillera: implications for continent-margin tectonism: Geology, v. 18, p. 276-280.

Sauer. K.B., Gordon, S.M., Miller, R.B., Vervoort, J.D., and Fisher, C.M., 2017a, Evolution of the Jura-Cretaceous North American Cordilleran margin: insights from detrital-zircon $\mathrm{U}-\mathrm{Pb}$ and $\mathrm{Hf}$ isotopes of sedimentary units of the North Cascades Range, Washington: Geosphere, v. 13, p. 2094-2118.

Sauer, K.B., Gordon, S.G., Miller, R.B., Vervoort, J.D., and Fisher, C.M., 2017b, Transfer of metasedimentary rocks to midcrustal depths in the North Cascades continental magmatic arc, Skagit Gneiss Complex, Washington: Tectonics, v. 36, p. $3254-3276$.

Sauer, K.B., Gordon, S.G., Miller, R.B., Jacobson, C.E., Grove, M., Vervoort, J.D., and Fisher, C.M., 2019, Deep-crustal metasedimentary rocks support Late Cretaceous "Mojave-BC" translation: Geology, v. 47, p. 99-102.

Schermer, E., 2017, Geochronologic constraints on the history of magmatism, metamorphism, and deformation in the Chelan Mountains terrane, NW Cascades crystalline core, WA: Geological Society of America Abstracts with Programs. v. 49, doi: 10.1130 .

Schiarizza, P., 2012, Geology of the Kutcho Assemblage between the Kehlechoa and the Tucho Rivers, Northern British Columbia (NTS 104I/01, 02), in Geological Fieldwork 2011: British Columbia Ministry of Energy, Mines and Natural Gas, British Columbia Geological Survey Paper 2012-01, p. 75-98. 
Schiarizza, P., 2013, The Wineglass assemblage, lower Chilcotin River, south-central British Columbia: Late Permian volcanic and plutonic rocks that correlate with the Kutcho assemblage of northern British Columbia, in Geological Fieldwork 2012: British Columbia Ministry of Energy, Mines and Natural Gas, British Columbia Geological Survey Paper 2013-01, p. 53-70.

Sharman, G.R., Graham, S.A., Grove, M., Kimbrough, D.L., and Wright, J.E., 2015, Detrital zircon provenance of the Late Cretaceous-Eocene California forearc: Influence of Laramide low-angle subduction on sediment dispersal and paleogeography: Geological Society of America Bulletin, v. 127 , p. $38-60$.

Shaw, S.E., Todd, V.R., Kimbrough, D.L., and Pearson, N.J., 2014, A west-to-east geologic transect across the Peninsular Ranges batholith, San Diego County, California: Zircon $176 \mathrm{Hf} / 177 \mathrm{Hf}$ evidence for the mixing of crustal- and mantle-derived magmas, and comparisons with the Sierra Nevada batholith: Geological Society of America, v. 211, p. $499-536$.

Stipp, M., Holer, S., Heilbronner, R., and Schmid, S.M., 2002, The eastern Tonale fault zone: a 'natural laboratory' for crystal plastic deformation of quartz over a temperature range from $250^{\circ}$ to $700^{\circ}$ C: Journal of Structural Geology, v. 24, p. 1861-1884.

Stowell, H.H., Bulman, G.R., Zuluaga, C.A., Tinkham, D.K., Miller, R.B., and Stein, E., 2007, Mid-crustal Late Cretaceous metamorphism in the Nason terrane, Cascades crystalline core, Washington, USA: implications for tectonic models, in Hatcher Jr., R.D., Carlson, M.P., McBride, J.H., Martinez Catalan, J.R., eds., 4-D Framework of Continental Crust: Boulder, Colorado, Geological Society of America, Memoir v. 200, p. 211-232.

Tabor, R.W., and Crowder, D.F., 1969, On batholiths and volcanoes-intrusion and eruption of Late Cenozoic magmas in the Glacier Peak area, North Cascades, Washington: Geological Survey Professional Paper 604, 65 p.

Tabor, R.W., and Haugerud, R.A., 1999, Geology of the North Cascades: Seattle, The Mountaineers, $143 \mathrm{p}$.

Tabor, R.W., Frizzel, V.A., Jr., Whetten, J.T., Wait, R.B., Swanson, D.A., Byerly, G.R., Booth, D.B., Hetherington, M.J., and Zartman, R.E., 1987, Geologic map of the Chelan 30-minute by 60-minute quadrangle, Washington: U.S. Geological Survey, Miscellaneous Investigation Series, Map I-1661, scale 1:100000.

Tabor, R.W., Haugerud, R.A., Miller, R.B., 1989, Overview of the geology of the North Cascades, in International Geological Congress, $28^{\text {th }}$, Fieldtrip Guidebook T307: Washington, D.C., American Geophysical Union, p. 1-33. 
Umhoefer, P.J., 1987, Northward translation of the "Baja British Columbia" along the Late Cretaceous to Paleocene margin of western North America: Tectonics, v. 6, p. 377394.

Umhoefer, P.J., and Miller, R.B., 1996, Mid-Cretaceous thrusting in the southern Coast Belt, British Columbia and Washington, after strike-slip fault reconstruction: Tectonics, v. 15 , p. 545-565.

Urai, J.L., 1987, Development of microstructure during deformation of carnallite and bischofite in transmitted light: Tectonophysics, v. 135, p. 251-263.

Valley, P.M., Whitney, D.L., Paterson, S.R., Miller, R.B., and Alsleben, H., 2003, Metamorphism of the deepest exposed arc rocks in the Cretaceous to Paleogene Cascades belt, Washington: evidence for large-scale vertical motion in a continental arc: Journal of Metamorphic Geology, v. 21, p. 203-220.

Vallier, T.L., 1977, The Permian and Triassic Seven Devils Group, western Idaho and northeastern Oregon: U.S. Geological Survey Professional Paper 1437, 56 p.

Vallier, T.L., Schmidt, K.L., and LaMaskin, T.A., 2016, Geology of the Wallowa terrane, Blue Mountains province, in the northern part of Hell's Canyon, Idaho, Washington, Oregon, in Lewis, R.S. and Schmidt, K.L., eds., Exploring the geology of inland northwest: Geological Society of America Field Guide 41, p. 211-245.

Walker, N.W., and Brown, E., W., 1991, Is the southeast Coast Plutonic Complex the consequence of accretion of the Insular superterrane? evidence from U-Pb zircon geochronometry in the northern Washington Cascades: Geology, v. 19, p.714-717.

Wernicke, B., and Getty, S.R., 1997, Intracrustal subduction and gravity currents in the deep crust: Sm-Nd, Ar-Ar, and thermobarometric constraints from the Skagit Gneiss Complex, Washington: Geological Society of America Bulletin, v. 109, p. 1149-1166.

Wyld, S.J., Umhoefer, P.J., and Wright, J.E., 2006, Reconstructing northern Cordilleran terranes along known Cretaceous and Cenozoic strike-slip faults: implication of the Baja British Columbia hypothesis and other models, in Haggart, J.W., Enkin, R.J., and Monger, J.W.H., eds., Paleogeography of the North American Cordillera: evidence for and against large-scale displacement: Geological Association of Canada Special Paper 46, p. 277-298. 


\section{APPENDIX A: EBSD POST-PROCESSING PROCEDURE}

1. Open the CHANNEL 5 software package.

2. Create a new file using the EBSD data acquired by the SEM.

3. Open the new file in the module "Tango"

4. Click "reduce wild spikes" once.

5. Apply only one iteration of a "6 neighbor zero solution".

6. Open the data file in the module "Mambo" by dragging the datafile into the icon.

7. Generate a pole plot of the data file. 


\section{APPENDIX B: ZIRCON SEPARATION PROCEDURE (SJSU)}

1. Crush rock sample using a rock pulverizer.

2. Mill the sample to sand-sized particles using an industrial disc mill.

3. Remove small low-density particles by running the sample on a Wilfley-table density separator set to a $\sim 15^{\circ}$ tilt with moderate water flow.

4. Remove low density silicates using heavy liquid separation with Bromoform.

5. Separate out ferromagnesian minerals using a Franz magnetic separator.

6. Isolate zircon, titanite, and garnet using heavy liquids separation with Methyl Iodide. 


\section{APPENDIX C: ZIRCON SEPARATION PROCEDURE (UNR)}

1. Break sample into tangerine-sized pieces using a sledgehammer.

2. Mill the sample using a custom-made steel mortar and pestle.

3. Sort milled sample in No. 40 sieve.

4. Place sieved sample in a $1000 \mathrm{~mL}$ beaker and wash repeatedly with water, until water becomes clear within 5 seconds of agitating sample with pressurized stream.

5. Place sample under heat lamp for 3-4 hours until completely dry.

6. Run sample through Frantz magnetic separator at the following settings:

a. 0.35 amperes $@ 20^{\circ}$

b. 0.60 amperes @20

7. Perform heavy liquid separation using methyl iodide solution.

8. Run heavy liquid separate through Frantz magnetic separator at the following settings:
a. 1.0 amperes $@ 20^{\circ}$
b.1.4 amperes@20
c.1.4 amperes @15 15
d.1.4 amperes@10
e.1.4 amperes@8 $8^{\circ}$
f. 1.4 amperes@6 $6^{\circ}$
g. 1.4 amperes@ $4^{\circ}$
h.1.4 amperes @2 $2^{\circ}$

9. Place final separate in petri dish and pick individual zircons if necessary. 


\section{APPENDIX D: PREPARATION OF FESEM MOUNT}

1. Apply sticky tape to back of a Pyrex dish.

2. Place a cylinder divided down the center into two half-cylinders on the sticky tape.

3. Cover one half of the cylinder with tape.

4. Pour zircons from one sample into the open half of the cylinder.

5. Remove cover from unused half of cylinder.

6. Place tape on the half of the cylinder in which zircons have already been poured.

7. Pour zircons from remaining sample into the open half of the cylinder.

8. Remove the split cylinder.

9. Flatten any upright zircons against the tape using tweezers under a compound microscope.

10. Remove unnecessary material, such as garnet or titanite.

11. Prepare epoxy resin.

12. Place plastic mount mold over zircons.

13. Use wooden stick to drip and smear epoxy across zircons, and pour remaining epoxy on zircons until the mount mold is filled with $\sim 1 \mathrm{~cm}$ of epoxy resin.

14. Wait 12 hours for epoxy resin to dry.

15. Remove dry mount from mold.

16. Make the mount cylindrical by using coarse sandpaper to remove extra epoxy around edges.

17. Use gradually finer grit to abrade zircons. Check periodically with compound microscope until a maximum number of zircons are exposed in cross section.

a. 800 grit, silica-diamond paper, 10 minutes

b. 1000 grit, silica-diamond paper, 10 minutes 
c. 1200 grit, silica-diamond paper, 10 minutes

d. 3-micron, silica paste, 1 minute

e. 1 micron, silica paste, $<1$ minute

18. Apply a 5-8 nm carbon coat on the mount using a Hi-Tech Instruments Q300T $\mathrm{T}$ Triple Target, Large Chamber, Turbo-Pumped Sputter Coater. 